Portland State University

PDXScholar

2-10-1995

\title{
The Biogeochemistry of Lakes in the Mount St. Helens Blast Zone
}

Victor Lee Menting

Portland State University

Follow this and additional works at: https://pdxscholar.library.pdx.edu/open_access_etds

Part of the Biology Commons

Let us know how access to this document benefits you.

Recommended Citation

Menting, Victor Lee, "The Biogeochemistry of Lakes in the Mount St. Helens Blast Zone" (1995).

Dissertations and Theses. Paper 4927.

https://doi.org/10.15760/etd.6803

This Thesis is brought to you for free and open access. It has been accepted for inclusion in Dissertations and Theses by an authorized administrator of PDXScholar. Please contact us if we can make this document more accessible: pdxscholar@pdx.edu. 
THESIS APPROVAL

The abstract and thesis of victor Lee Menting for the Master of Science in Biology was presented February 10, 1995, and accepted by the thesis committee and the department.

COMMITTEE APPROVALS

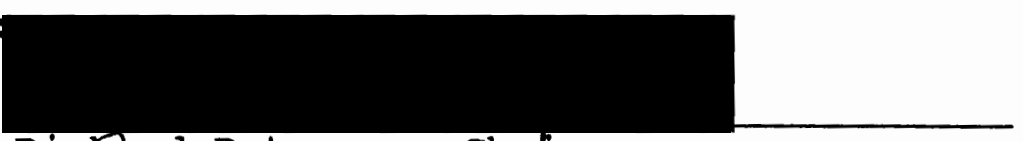
Righard Peterson, Chair

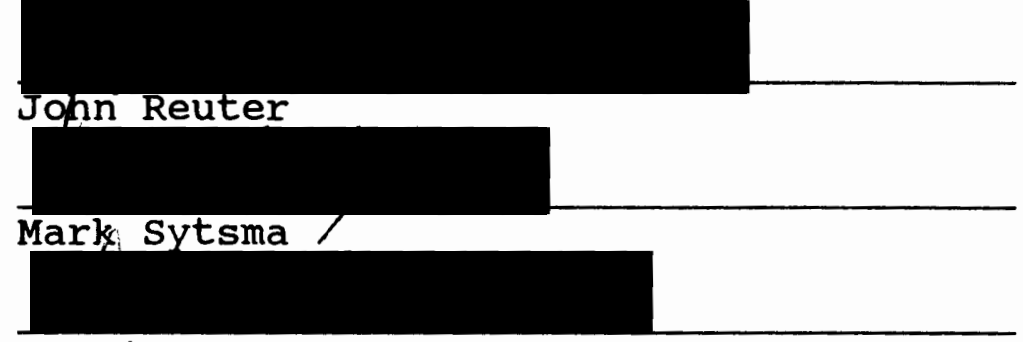

Dennis Barnum

DEPARTMENTAL APPROVAL:

Leonard Simpson, Chair

Department of Biology

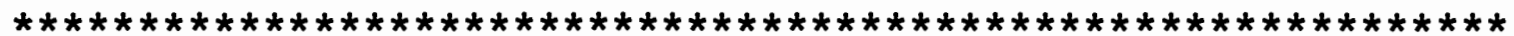
ACCEPTED FOR PORTLAND STATE UNIVERSITY BY THE LIBRARY by

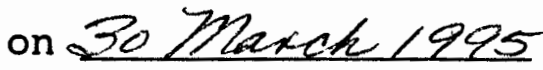




\section{ABSTRACT}

An abstract of the thesis of Victor Lee Menting for the Master of Science in Biology presented February 10, 1995.

Title: The Biogeochemistry of Lakes In The Mount st. Helens Blast Zone.

Dilution and ash weathering are the most important processes controlling the ion chemistry of lakes in the Mount St. Helens blast zone. Gibbs' models indicated total dissolved solids were decreasing as a result of dilution from high precipitation and runoff and the lakes plot in the rock weathering dominated region. Plots of theoretical dilution curves indicated a decline in ion concentrations as a result of dilution. Ion concentrations followed the exponential decline predicted by the dilution curve, although concentrations were higher than predicted by the curve. Increased concentrations were a result of the rapid weathering of ash in basins and on lake bottoms.

Rapid weathering of ash in lake watersheds and on lake bottoms continues to influence the ionic concentrations of the lakes. In general, sodium and potassium have declined at a much faster rate than calcium or magnesium. Slower relative declines in concentrations of calcium and magnesium were a result of more rapid rate of leaching of calcium and 
magnesium from the ash.

Ash in the watersheds will continue to be a major contributor to the overall ion chemistry of the lakes until such time as the watersheds are stabilized by vegetation and a permanent soil layer. Ash on lake bottoms will be unavailable as sources of ionic constituents when it becomes buried within deep sediment layers.

Ion concentrations observed in study lakes affected by the eruption were similar to those observed in control lakes with few exceptions. Although ion concentrations in affected lakes have declined to values observed in control lakes, most were at higher concentrations than the regional means.

Several functions of the ion chemistry were used to correlate planktonic community structure to lake ion chemistry. The data suggested ion chemistry was not influencing biological community structures as no patterns emerged. Analysis of diatom populations with respect to monovalent:divalent cation ratios showed no correlation. 
THE BIOGEOCHEMISTRY OF LAKES IN THE

MOUNT ST. HELENS BLAST ZONE

by

VICTOR LEE MENTING

A thesis submitted in partial fulfillment of the requirements for the degree of

MASTER OF SCIENCE

in

BIOLOGY

Portland state University

1995 


\section{DEDICATION}

This work is dedicated to my wife, Heidi, for her parience and understanding during this investigation. For her supprot through the tough times and late nights I am forever indebted. 


\section{ACKNOWLEDGEMENTS}

I would like to thank the numerous people who have been involved and helpful in making this project possible. I am grateful for the friendship and many helpful comments and suggestions from my colleagues; Cindy Baker, Gary Burns, Kurt Carpenter, Steve Daggett, Kris Hueftel, Valerie Kelly, Larry Scharnberg, and Allen Vogel.

I appreciate the many helpful comments and suggestions from Mark Sytsma and Doug Larson in reviewing this manuscript. A special thank you goes to my Thesis Defence/Oral Examination Committee; John Rueter, Mark Sytsma, and Dennis Barnum.

Last, but certainly not least, I am grateful to Richard Petersen for sharing his wealth of knowledge. His insights greatly aided me in the completion of this investigation. 
TABLE OF CONTENTS

PAGE

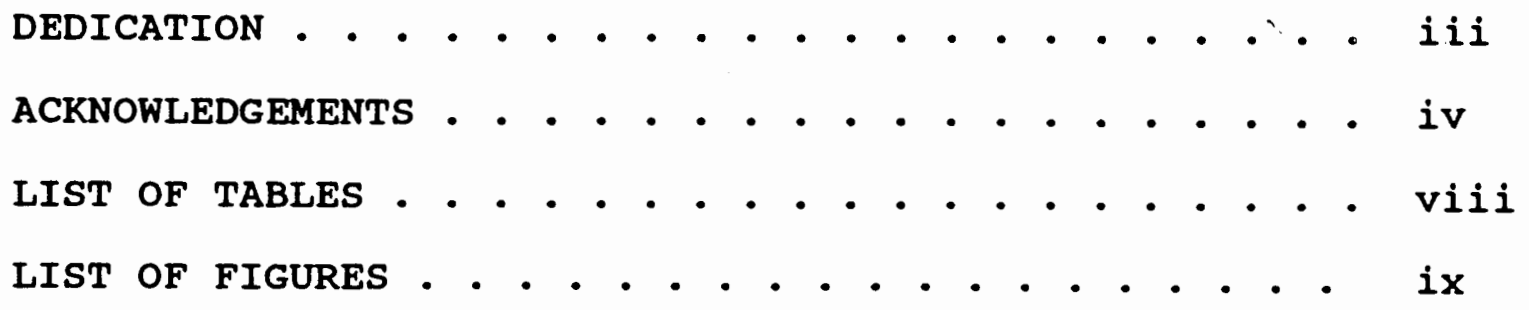

CHAPTER

I INTRODUCTION • . . . . . . . . . . . . . 1

Historical Background . . . . . . . 1

Processes Controlling Lake Chemistry . . 3

Chemical Constituents

Processes of Interest

Conceptual Model

Impact of Water Chemistry on Lake

Biology • • • • • . • • • • . • 9

Purpose . . . . . . . . . . . . 11

II SUMMARY OF PAST STUDIES • . . . . . . . . . . 12

Physical Charasteristics . . . . . . 12

Lake Descriptions . . . . . . . . 12

Limnological Charasteristics . . . . 18

Ion Data

Biological Data

Basin Charasteristics . . . . . . 20

Ash Data

Precipitation Data 
III EXPERIMENTAL . . . . . . . . . . . . . 24

Materials . . . . . . . . . . 24

Water

Acid Baths/cleaning Protocol

Methods . . . . . . . . . . . 25

Sampling

Laboratory Procedures

IV RESULTS . . . . . . . . . . . . . . 31

Analysis of Chemical Data . . . . . 31

Current study

Trends In The Chemical Data

Analysis of Biological Data . . . . 61

Planktonic Communities

Cluster Analysis

M:D Ratio And Diatom Density

V DISCUSSION . . . . . . . . . . 76

VI REFERENCES . . . . . . . . . . . . 79

APPENDICES

A REFERENCES AND METHODOLOGIES UTILIZED FOR THE DETERMINATION OF THE PHYSICAL CHARASTERISTICS OF THE LAKES . . . . . . . . . . . . 83

B CHEMICAL DATA FROM PAST LAKE STUDIES • • . 87

C COMPARISON OF CATION CONCENTRATIONS OBTAINED BY STANDARD CURVE AND KNOWN ADDITION . . . 100 
vii

D COMPARISON OF DETERMINED "UNKNOWN" CATION CONCENTRATIONS AND "TRUE" CONCENTRATIONS FOR STANDARD CURVE AND KNOWN ADDITION . . . . . 105

E CURRENT CHEMICAL DATA COLLECTED FROM 1993 AND 1994 LAKE SAMPLES . . . . . . . . . . 108

F TEMPERATURE PROFILES OF STUDY LAKES • • • • 129 


\section{LIST OF TABLES}

TABLE

PAGE

I Physical Charasteristics of Study Lakes . . . 13

II Average Cation Concentrations of Lakes Located In The South Washington Cascade Mountains . . 19

III Water-Soluble Constituents In Mount st. Helens Ash . . . . . . . . . . . . . . . . 22

IV Average Ion Concentrations In Precipitation . 23

V Sampling Dates For 1993 And 1994 . . . . 25

VI Instrument Parameters For Cation Analysis By Atomic Absorption Spectrophotometry . . . . 28

VII Instrument Parameters For Anion Analysis By Ion Chromatography . . . . . . . . . 30

VIII Phytoplankton And Zooplankton clusters For 1991 And 1993 . . . . . . . . . . 64 
LIST OF FIGURES

FIGURE

PAGE

1. Revised Gibbs Model . . . . . . . . . 6

2. Steady state Model And theoritical Dilution Curve . . . . . . . . . . . . . . 10

3. Precipitation Effect on Control Lakes . . . 38

4. Volume Effect On Ion Concentrations . . . . 41

5. Distance Effect on Initial Concentrations . . 42

6. Change In Ion Concentration As A Result of

Lake Volume . . . . . . . . . . . . 44

7. Panhandle Lake Dilution Model . . . . . . 47

8. Boot Lake Dilution Model . . . . . . . . 48

9. Fawn Lake Dilution Model . . . . . . . . 49

10. St. Helens Lake Dilution Model . . . . . 50

11. Venus Lake Dilution Model . . . . . . . 51

12. Castle Lake Dilution Model . . . . . . 55

13. Coldwater Lake Dilution Model . . . . . . 56

14. Gibbs Model - Part A. . . . . . . . . 58

15. Gibbs Model - Part B . . . . . . . . 59

16. Gibbs Model - Part C . . . . . . . . 60

17. Ca/Na Effect on Zooplankton Communities . . 66

18. Ca/Mg Effect on Phytoplankton Communities . . 67 
19. M:D Cation Ratio Effect on Zooplankton Communities . . . . . . . . . . . . 68

20. Cation Sum Effect on Phytoplankton

Communities . . . . . . . . . . . . 69

21. Alkalinity Effect on Phytoplankton

Communities . . . . . . . . . . . . 70

22. Conductivity Effect on zooplankton

Communities . . . . . . . . . . . 71

23. TDS Effect on Phytoplankton Communities . . 72

24. M:D Cation Ratio Effect on 1991 Diatoms . . 74

25. M:D Cation Ratio Effect on 1993 Diatoms . . 75 
CHAPTER I

INTRODUCTION

\section{HISTORICAI BACKGROUND}

The 18 May 1980 eruption of Mount st. Helens removed an estimated $4 \mathrm{~km}^{3}$ (1 cubic mile) of pyroclastic material (Fruchter, et al., 1980) from the top and northeast slope of the mountain. As a result of the eruption, an avalanche of mud, debris, and ash flowed down the north slope into the Toutle River Valley damming East Castle, West Castle, South Coldwater, and North Coldwater Creeks on the North Fork of the Toutle River. Damming of these creeks resulted in the formation of two new lakes, Castle and coldwater Lakes (Wissmar, 1982).

The avalanche also deposited large quantities of volcanic debris and vegetation in lakes and their drainage basins. Hot ash and debris settled throughout the Mount st. Helens area. Debris and ash layers up to $3 \mathrm{~m}$ deep were deposited in some areas and rock slides filled drainage basins with as much as $70 \mathrm{~m}$ of debris (Rushforth, et al., 1986).

Prior to the eruption of Mount st. Helens, the preexisting lake compositions can be thought of as in equilibrium with the surroundings (Benoit, 1969). A mass 
balance equation can be written to show the sources of ionic constituents involved before and after the eruption (Drever, 1982)

Rock Weathering + Atmospheric Input

$$
=\text { sediment }+ \text { solution }
$$

Atmospheric input consists of water, carbon dioxide, dry fallout, and dissolved species in precipitation. sediment consists of buried sediments which do not contribute chemical species to the water column. Rock weathering includes the weathering of soils, minerals, and ash within the watershed, as well as surface lake sediments which actively undergo reactions with and contribute ions to the water column.

After the eruption rock weathering can be split into two components: (1) Background rock weathering and (2) Weathering of new ash. Background rock weathering was present prior to the eruption and probably continues in the same manner where there is little ash cover or deep within soils covered with ash.

Freshly deposited ash was fine particulate material which weathered rapidly and continues to weather rapidly (Wissmar, et al., 1982). Ash deposited within drainage basins remains a source of constituents until the basin is stabilized by vegetation and a permanent soil layer develops (Klock, 1982). Ash that enters a lake settles rather quickly, with finer particles settling at a slower rate 
(Edmondson, 1984), Edmondson also stated that once these particles settle, they can become covered with other sediment and gradually cease to be a source of ions to the water column. While exposed, ash on the lake bottoms can be a source of dissolved constituents.

The eruption disrupted the equilibrium by drastically altering the chemical composition of lakes in the blast zone through the input of fallen timber and volcanic debris. wissmar, et al. (1982) reported concentrations of calcium, magnesium, sodium and potassium in lakes of the blast zone increased by as much as forty times the levels in control lakes. Concentrations of chloride, sulfate, and bicarbonate were reported to be as much as two orders of magnitude higher in blast-affected lakes. Wissmar, et al. (1982) attributed these increases to chemical weathering and hydrothermal processes, which occurred rapidly on the highly reactive particles in the warm pyroclastic flows. High reactivity of particles was a result of small size and large surface area (wissmar, et al., 1982).

\section{PROCESSES CONTROLLING LAKE CHEMISTRY}

\section{Chemical constituents}

Ions considered in this report are the major cations (Sodium, $\mathrm{Na}^{+} ;$Potassium, $\mathrm{K}^{+} ;$Calcium, $\mathrm{Ca}^{2+} ;$ and Magnesium, $\mathrm{Mg}^{2+}$ ) and the three major anions (Chloride, $\mathrm{Cl}^{-}$; sulfate, $\mathrm{SO}_{4}{ }^{2-} ;$ and Bicarbonate, $\mathrm{HCO}_{3}{ }^{-}$). Alkalinity and conductivity 
were also measured. Alkalinity is directly related to the concentration of carbonate species in solution, and conductivity is the result of the conductivities of the individual ions.

Processes of Interest

There are several mechanisms and processes which effect the major ion concentrations of lakes. Gibbs (1970) discussed three mechanisms which control the chemistry of surface water. He described three controlling mechanisms: (1) atmospheric domination, (2) rock weathering, and (3) evaporation and crystallization. Based upon these three mechanisms, Gibbs concluded the importance of each mechanism could be determined by plotting the weight ratio $\mathrm{Na} /(\mathrm{Na}+\mathrm{Ca})$ versus total dissolved salts. Gibbs' model has recently been criticized (Kilham, 1990 and Eilers, et al., 1992) as it does not thoroughly describe all the world's lakes.

Kilham demonstrated that African waters are controlled by rock weathering reactions and the evaporationcrystallization process and showed substantial deviation between Gibbs' envelope and African hard-water systems. The envelope of data from these waters plot as a chemist's retort rather than a boomerang. Eilers, et al. studied dilute lakes in the western and north-central U.S. and found that only exceptional lakes plotted within Gibbs' envelope. They suggested that Gibbs' model can be misleading in interpreting lake-water chemistry and processes controlling 
lake chemistry.

None of the challenges disputed that surface water chemistry is controlled by the three aforementioned mechanisms. They suggest other watershed processes and local variations in hydrologic flowpaths and local geology can modify surface-water chemistry. Gibbs has, however, modified his model (Figure 1) to include small lakes (Gibbs considers these to be "minor" lakes) in remote areas (Gibbs, $1992)$.

Atmospheric dominance controls the chemical composition of low-salinity waters by the amount of dissolved salts in precipitation (Gibbs, 1970). Gibbs states these waters consist mainly of tropical waters of Africa and South America. In the Mount st. Helens lakes, atmospheric dominance would not be considered to be an important mechanism considering the quantity of dissolved salts supplied by the ash.

Although evaporation, therefore crystallization, takes place in all climates, it is only in relatively hot, arid climates that the buildup of dissolved salts through evaporation is a major control on water chemistry (Gibbs, 1970, and Drever, 1982). Evaporation and crystallization would not be considered an important mechanism in alpine lakes which receive substantial precipitation.

The chemistry of most surface water is the result of interaction between rain and rock near the earth's surface 
Figure 1. Revised Gibbs Model

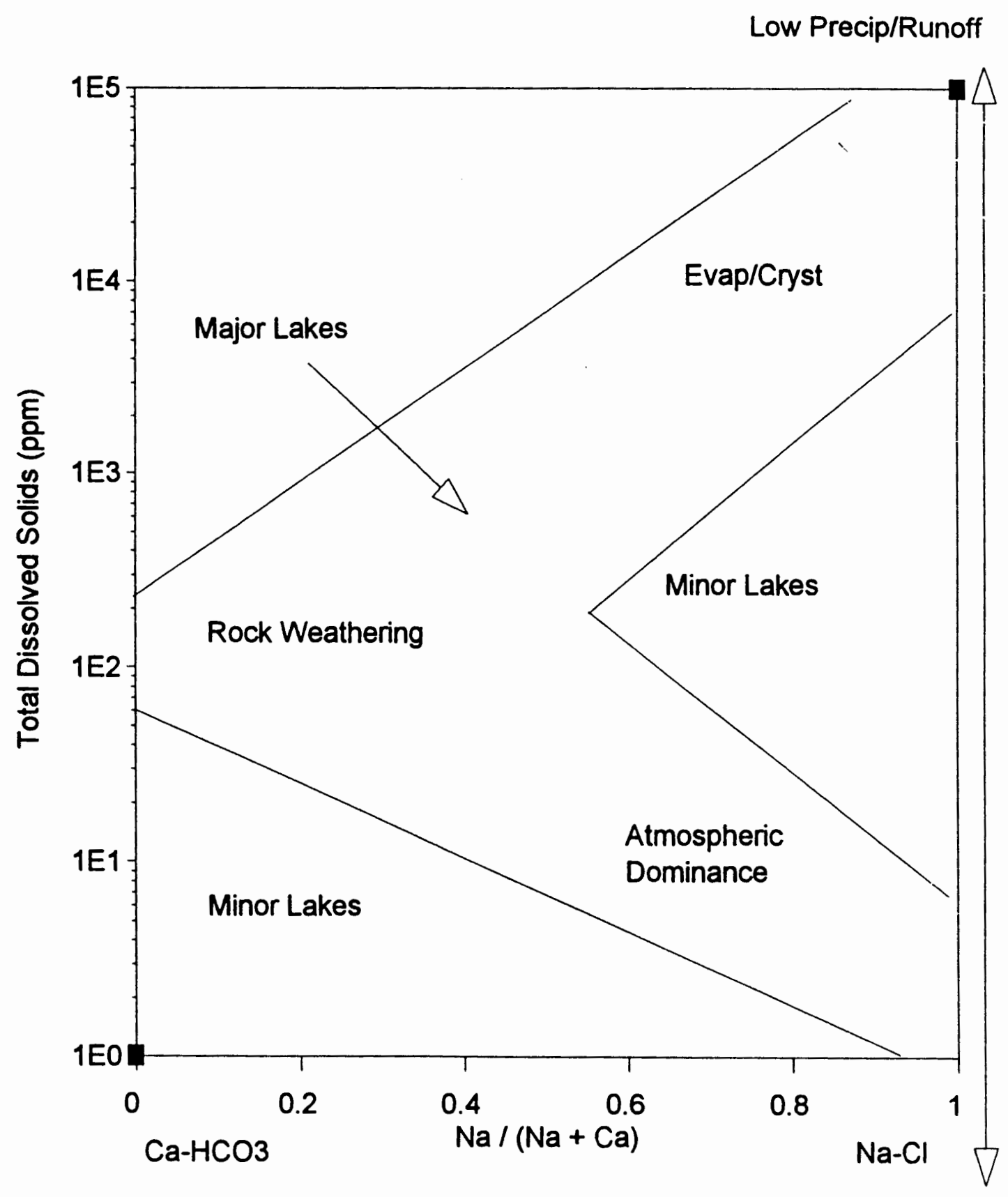

High Precip/Runoff 
(Drever, 1982). With enormous quantities of ash and volcanic debris in the lakes and their basins, it would not be surprising for an important mechanism controlling the chemistry of these lakes to be rapid ash weathering. It would also be expected that after catastrophic inputs of ions, dilution by atmospheric precipitation would be an important mechanism by which lakes return to their prior equilibrium.

\section{Conceptual Model}

Lakes in this study are exorheic lakes (open basins with an outlet), so their chemical composition was determined mainly by the chemical composition of inflow. Conditions which determine the chemical composition of inflow include the ionic composition of precipitation, composition of the surrounding drainage basin, and equilibrium reactions which occur in basin soils (Hutchinson, 1975). Inflow for these lakes was principally a result of rapid weathering of ash by precipitation although groundwater seepage may have been a contributing factor. Since precipitation partly controls the chemical composition of the lakes, concentrations of the chemical constituents of the lakes will vary with annual precipitation of the region.

While fresh volcanic ash can release material into solution, most of the material is relatively insoluble (Edmondson, 1984). Even though most of the ash was 
relatively insoluble, the large quantities of chemical. constituents measured in the blast zone lakes during the summer of 1980 was attributed to enormous amounts of ash deposited into the lakes and basins (Wissmar, et al., 1982). After the initial post-eruption amounts of chemical constituents entered the lakes, another process, dilution, would be expected to decrease concentrations.

The reduction of ion concentrations by the influx of large quantities of more dilute water can be predicted by the equation (Welch, 1979):

$$
c_{t}=c_{i}+\left(c_{0}-C_{1}\right) e^{-K t}
$$

where $c_{t}$ is the concentration at time $t, c_{i}$ is the concentration of the influx water, $c_{0}$ is the initial lake concentration, and $\mathrm{K}$ is the water exchange rate (reciprocal of lake residence time). This equation assumes the lake is well mixed and there is no other source of ionic inputs. Equation 2 predicts ionic concentrations will decline exponentially as a function of lake residence time and chronological time.

Graphs of the idealized dilution models, calculated from Equation 2, were used to determine the extent to which dilution played a role in the chemical composition of the lakes. Deviations in the yearly normalized ${ }^{1}$ ion concentrations from those predicted from the idealized

\footnotetext{
${ }^{1}$ Normalized ion concentrations are yearly ion concentrations divided by the 1980 concentrations so all four cations are similarly scaled and normalized to 1 in 1980 .
} 
dilution model can be attributed to the rapid weathering of ash on the landscape and on the lake bottom (Figure 2).

Dilution models were extreme cases where the concentration of the inflow water was a result of the ion concentrations in precipitation, and assumed to be insignificant with respect to the ion concentrations in lake water. Since annual precipitation varies, water exchange rates, $\mathrm{K}$, were determined for each year.

\section{IMPACT OF WATER CHEMISTRY ON LAKE BIOLOGY}

The planktonic communities were also affected by the eruption of Mount st. Helens. Major changes in lake biology were caused by ash and other materials introduced into the lakes. For purposes of this investigation, focus was placed on the biological effects of increased concentrations of chemical compounds.

Planktonic community structure of a lake can be controlled, in part, by the concentrations of the dissolved constituents (Guillard, 1962). The distribution of certain planktonic species has been correlated to differing concentrations of major ions (Provasoli, 1958 and O'Kelly, 1968). Many planktonic organisms flourish in lakes rich in particular ionic species, while other species may be restricted by increased concentrations.

Guillard (1962) discussed two main effects chemical constituents have on aquatic organisms. The first is 
Figure 2. Steady State Model And Theoritical Dilution Curve

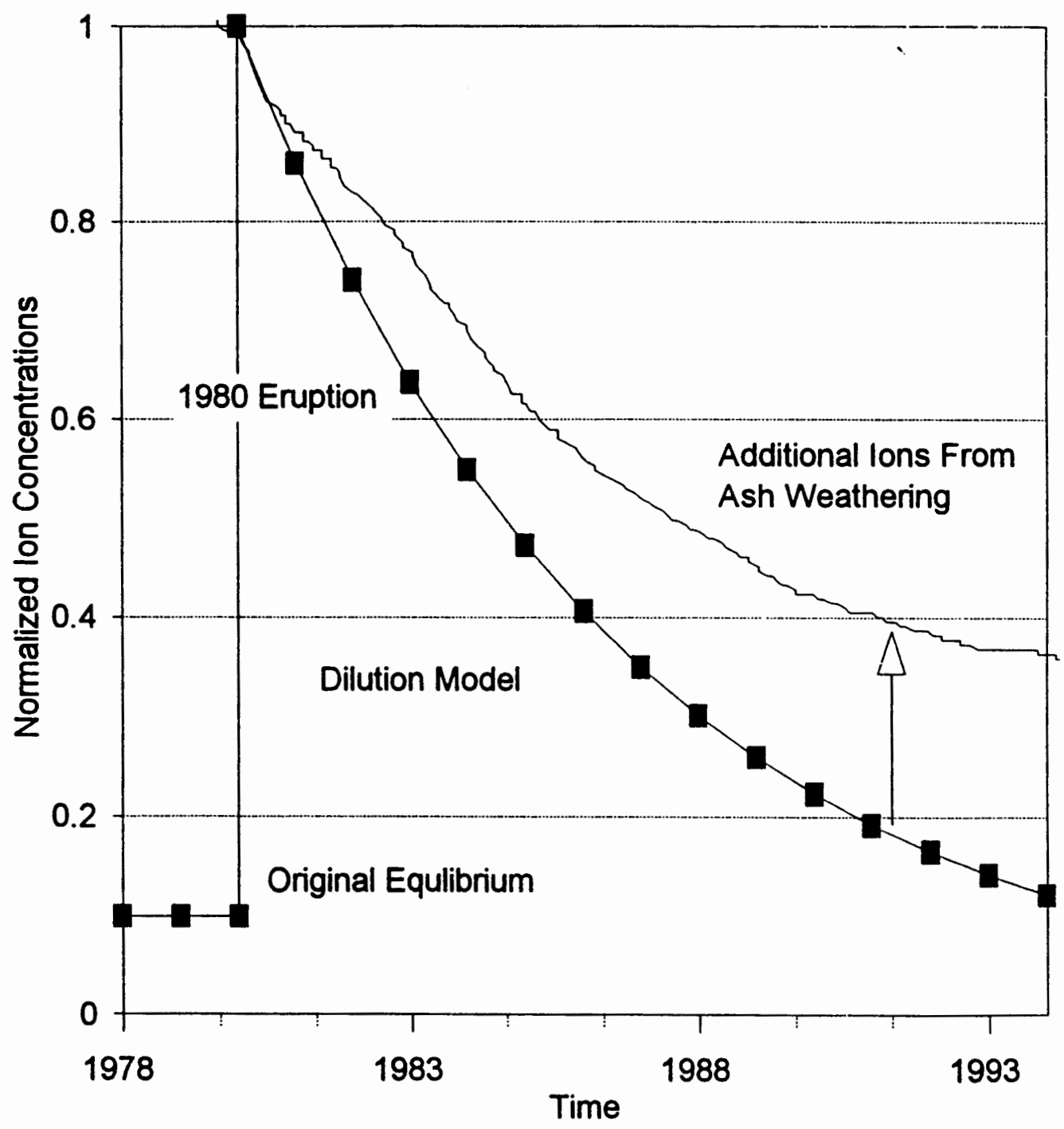


related to the concentration of the specific chemical constituents and their actions on living cells. The second, an osmotic effect, depends upon the total dissolved solids, and a species' ability to regulate the movement of water into and out of cells.

Wetzel (1983) discussed the importance of the monovalent to divalent cation ratio (M:D) regarding the distribution and dynamics of algae and larger aquatic plants in fresh waters. A M:D ratio below 1.5 is favorable to diatoms and much higher ratios favor desmid algae.

There is danger in generalizing about the role of ionic concentrations on the planktonic species present, as there are a few populations of organisms which can thrive in waters with very unusual ionic compositions.

\section{PURPOSE}

The purpose of this investigation was (1) to determine the major ion chemistry of lakes in the Mount st. Helens blast zone and to assess the relative importance of the mechanisms and processes that control major ion chemistry, and (2) to assess the influence of the ion chemistry on planktonic community composition. 
CHAPTER II

SUMMARY OF PAST STUDIES

PHYSICAL CHARACTERISTICS

Twelve lakes located in the Mount st. Helens National Forest were examined in this study. Nine lakes, affected by the eruption were the focus of this study. Hanaford, Fawn, st. Helens, Venus, Panhandle, Boot, and Ryan Lakes were within the blast zone. Castle and Coldwater Lakes were newly formed by the eruption. Merrill, McBride, and June Lakes, which were not affected by the eruption, were used as unaffected "control" lakes.

\section{LAKE DESCRIPTIONS}

Lakes in the study are sub-alpine lakes which differ vastly in physical characteristics (Table I). Physical characteristics of the lakes aided in interpretation of the data obtained.

Panhandle Lake is located in the blast zone region where timber blowdown and ashfall was heaviest. Panhandle Lake, located $16 \mathrm{~km}$ north-northeast from the volcano, was partly shielded from the blast by mountain ridges. Although partly shielded, trees were blown down and logs were blown into the lake. 
TABLE I

PHYSICAL CHARACTERISTICS OF STUDY LAAKES ${ }^{1}$

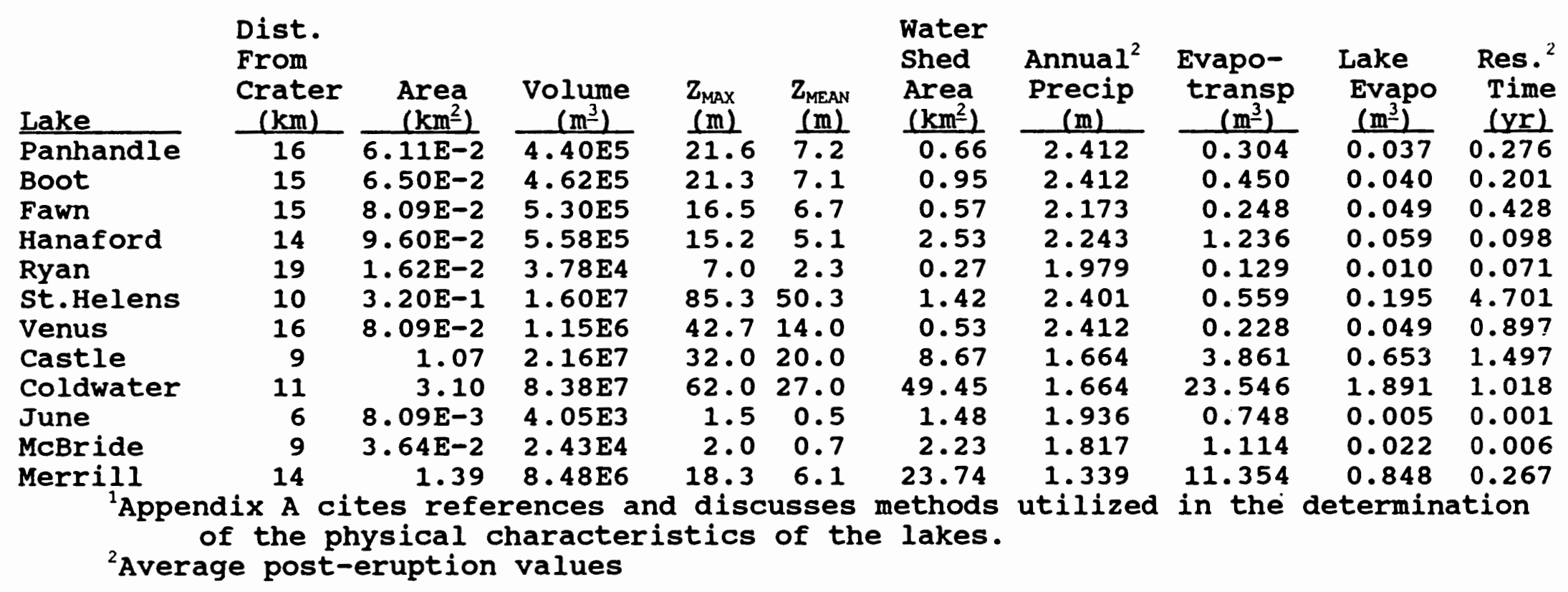


Boot Lake is Jocated $15 \mathrm{~km}$ from the volcano. Like Panhandle Lake, Boot Lake is in the blast zone region where timber blowdown and ashfall was heaviest, but was partially shielded by mountain ridges.

Fawn Lake is located $15 \mathrm{~km}$ north-northwest of the volcano and received 0.4 to 1.2 inches of ashfall YDoug Lee, personal communication). The lake was exposed on a ridge overlooking coldwater creek, and was directly affected by the blast. Trees in the basin were blown down and stripped of bark, branches, and leaves. Fawn Lake was covered with ice at the time of the eruption and, therefore, was not as severely affected as lakes further away from the blast which were not protected by ice cover (Mcknight, et al., 1984). Hanaford Lake is located in the region of the blast zone where blown down timber and ashfall was the heaviest. The lake, located $14 \mathrm{~km}$ from the volcano, was covered with ice at the time of the blast (Dion and Embry, 1981). Although the lake was exposed on a ridge over Coldwater Creek, staley, et al. (1982) consider Hanaford Lake to have been less affected by the eruption than other lakes in the blast zone due to ice cover.

Ryan Lake is $19 \mathrm{~km}$ north of Mount st. Helens. The lake is located in the "timber blowdown" region of the blast zone. Foliage in the area was pyrolized (chemically altered by heat) by temperatures in excess of $250^{\circ} \mathrm{C}$ (Dahm, et al., 1983). Ryan Lake was partly shielded by nearby mountain 
ridges (Wissmar, et al., 1982), but ashfall in the area was estimated to be 3.9 to 7.9 inches (Dahm, et al., 1983).

st. Helens Lake is directly north of the volcano in line with the initial blast, but did not receive a direct flow of avalanche material (Embry and Dion, 1988). The initial blast leveled surrounding timber, much of which ended up in the lake. st. Helens Lake received considerable volcanic material which fell into the lake or slid into it from steep surrounding slopes (Embry and Dion, 1988).

Venus Lake, which is $16 \mathrm{~km}$ from the crater, received heavy input of volcanic debris (Embry and Dion, 1988). The blast leveled most trees while others were stripped of bark, leaves, and branches, although none of the timber was blown into the lake (Embry and Dion, 1988). Distance from the volcano and cushioning effect of mountain ridges prevented the blown down timber from entering the lake.

Castle Lake is $9 \mathrm{~km}$ northwest of Mount st. Helens and was formed at the time of the 1980 eruption by an avalanche and mudflow which dammed castle creek, a tributary of the North Fork Toutle River. Castle Lake had a depth of 11 meters by the summer of 1980 (wissmar, et al., 1982), but the current maximum depth is 32 meters (Kel1y, 1992). According to Mcknight, et al. (1984, p.3):

The volume of South Fork Castle Lake [Castle Lake] increased by about 14 times from 1100 acre-feet on September 30, 1980, to 14960 acre-feet on May 27, 1981. During the summer and fall of 1981 the rate of increase in 
the volume of Castle Lake slowed. Moknight, et al. (1984) also reported the lake's surface was partly covered with fallen timber.

Coldwater Lake was created by the avalanche and mudflow damming coldwater creek. Coldwater Lake is $11 \mathrm{~km}$ from the crater and had a depth of 34 meters by the summer of 1980 (Kelly, 1992). The current maximum depth was reported to be 62 meters (Kelly, 1992). North Coldwater creek flows into Coldwater Lake. Initially, South Coldwater creek flowed into Coldwater Lake as well.

An avalanche of volcanic debris dammed the natural outlet of spirit Lake, producing a hydrologically unstable basin. The threat of spirit Lake breaching or overtopping the debris dam and creating a flood downstream into the North Fork Toutle River, caused the U.S. Army Corps of Engineers to initiate a temporary pumping station in November 1982 to stabilize the lake surface elevation. Approximately $111 \times 10^{6}$ cubic meters of water were pumped from spirit Lake into South Coldwater creek from November 1982 until 1985 (Larson and Glass, 1987). In 1985 a tunnel outlet for spirit Lake was constructed which discharged water into the North Fork Toutle river via south Coldwater Creek (Larson and Glass, 1987). Erosion of volcanic debris and ashfall from the watershed of south coldwater creek, along with the high ionic content of spirit Lake-water, emptied into Coldwater Lake. Much of the eroded material 
was deposited near the lake inflow and resulted in an increase in the size of the coldwater creek delta in Coldwater Lake (Larson and Glass, 1987). The increased delta size reduced the amount of water flowing into Coldwater Lake. The majority of the water in Coldwater Creek now bypasses coldwater Lake, and flows directly into the lake outlet, South coldwater creek.

June, McBride, and Merrill Lakes, considered to have been unaffected by the eruption (Baross, et al., 1982), have been used for comparative analyses. June Lake is southeast of the volcano and received only minimal ashfall. Although June Lakes is outside the blast zone and had been considered an unaffected, control lake, wissmar, et al. (1982) noted some apparent changes in the chemical characteristics of the lake after the eruption. June Lake is fed by glacial runoff which flows over a volcanic avalanche from a previous eruption and by a waterfall on the east side of the lake. MCBride Lake received only a small, unmeasured amount of ash and was considered by many authors (Smith and white, 1985; Baross, et al., 1982; and staley, et al., 1982) to have been an unaffected control lake. McBride Lake is southwest of Mount St. Helens and has been described as a steep basin surrounded by a conifer forest (Smith and White, 1985). The lake itself is very shallow. Smith and white (1985) stated water flowing into the lake had passed over ashfall and water flowing out of the lake was relatively 
free of particles. McBride Lake, as well as Merrill and June Lakes, experienced little chemical change as a result of the eruption (Baross, et al., 1982).

Merrill Lake, which is southwest of the volcano, was regarded by Baross, et al. (1982) to have been unaffected by the eruption, although it received a small, unmeasured amount of ash. The lake is located in a forested watershed with one-fourth of the littoral covered with aquatic plants. Although Merrill Lake was considered a control lake, Baross, et al. (1982) focused on McBride Lake for comparative analysis.

\section{LIMNOLOGICAL CHARACTERISTICS}

The eruption of Mount St. Helens has created an excellent opportunity to study the effects of a catastrophic event on the surrounding environment. The opportunity has drawn a large number of scientists from a variety of fields and has generated an abundance of data.

In 1980, shortly after the eruption, the aforementioned lakes were studied extensively by wissmar, et al. (1982). Smith and White (1985) studied McBride Lake in 1982. Kelly (1992) reported data from several studies on Castle and Coldwater Lakes from 1981 through 1984 and 1989. The other lakes were not studied again until petersen (1993) reported ion and plankton data for the lakes. Data reported in this study for 1993 and 1994 were part of an ongoing limnological 
analysis begun by Petersen.

Ion Data

Historical chemical data on the lakes were typically from summer surface samples. Data for assessing mechanisms and processes in this study were taken from surface concentrations of summer samples. For lakes with two sample sites, data from the station located over the deepest part of the lake were used. The available chemical data for each lake from the time of the eruption of Mount st. Helens, including the values obtained in this investigation, were reported (Appendix B).

Concentrations of ions in blast zone lakes were compared with data collected from lakes outside the blast zone. Landers, et al. (1987) presented average cation concentrations for lakes located in the south washington Cascade Mountains which provided additional data for comparison (Table II).

TABLE II

AVERAGE CATION CONCENTRATIONS OF LAKES LOCATED IN THE SOUTH WASHINGTON CASCADE MOUNTAINS

(Concentrations in $\mathrm{mg} / \mathrm{L}$ )

$\begin{array}{lc}\text { Ion } & \text { Concentration } \\ \mathrm{Ca} & 3.29 \\ \mathrm{Mg} & 0.58 \\ \mathrm{Na} & 0.80 \\ \mathrm{~K} & 0.16\end{array}$




\section{Biological Data}

Detailed summaries of planktonic communities for each lake for 1991 and 1993 have been reported. While biological data exists for previous years, it was incomplete for the purposes of this investigation.

Phytoplankton data were obtained from Jim Sweet (personal communication) for 1991 and Baker (1995) for 1993. Allen Vogel (personal communication) reported zooplankton data for 1991. Zooplankton data for 1993 was reported by Scharnberg (1995).

Data for assessing the influence of ion chemistry on planktonic community composition were taken from surface communities of summer samples. For lakes with two sample sites, data from the station located over the deepest part of the lake were used.

\section{BASIN CHARACTERISTICS}

Mechanisms occurring in lake basins have a significant effect on ion chemistry and planktonic community composition of lakes. The two main factors affecting the basins were volcanic ash and annual precipitation.

\section{Ash Data}

Due to the importance of volcanic ash on the chemistry of lakes, it was imperative that the chemical composition of Mount st. Helens ash be determined. Numerous reports have been published that examine the chemical composition of 
Mount st. Helens ash (Edmondson, 1984; Hoffer, et al., 1982 ; Fruchter, et al., 1980; Hoffer and Hoffer, 1986 ; Ikramuddin, et al., 1982; and Taylor and Lichte, 1980) and of ash leachate (McKnight, et al., 1981 and Hinkley and Smith, 1987)

Fruchter, et al. (1980) studied the composition of Mount st. Helens ash deposits at several locations in eastern Washington and Montana and reported the concentrations of major constituents in a 10:1 mixture of distilled water and Mount St. Helens ash (Table III). Concentrations of water-soluble constituents were highly variable from location to location. Values presented by Fruchter, et al. (1980) were representative of values presented by all authors on the composition of soluble constituents of the volcanic ash. Dethier, et al. (1981) reported from a written communication from Collier (1980) that calcium, magnesium, chloride, and sulfate showed the fastest weathering rates from the ash. Dethier, et al. (1981) also discussed the mobility of ions from the ash. Chloride and sulfate are highly mobile, followed by calcium, sodium, and magnesium, with potassium being relatively immobile.

McKnight, et al. (1981) reported leachates of Mount st. Helens ash contained high concentrations of important algal nutrients such as phosphate, nitrate, and ammonia, as well as dissolved organic carbon. They also presented data which 
indicate that, relarive to natural surface waters in the affected area, leachates contained high concentrations of the toxic trace elements manganese, zinc, copper, and cadmium. Toxic organic compounds have also been identified in ash (Mcknight, et al. 1981). It is thought that these toxic organic compounds originated as breakdown products of pyrolized plant materials.

TABLE III

WATER-SOLUBLE CONSTITUENTS

IN MOUNT ST. HELENS ASH

(Concentrations in $\mathrm{mg} / \mathrm{L}$ )

$\begin{array}{lccccc}\text { Ion } & \begin{array}{c}\text { Tieton } \\ (98 \mathrm{~km})\end{array} & \begin{array}{c}\text { Yakima } \\ (137 \mathrm{~km})\end{array} & \begin{array}{c}\text { Spokane } \\ (378 \mathrm{~km})\end{array} & \begin{array}{c}\text { Missoula } \\ (644 \mathrm{~km})\end{array} & \frac{\text { Average }^{\prime}}{29.6} \\ \mathrm{Ca} & 18.0 & 8.5 & 22.0 & 40.0 & 3.3 \\ \mathrm{Mg} & 2.3 & 1.1 & 6.5 & 4.0 & 19.2 \\ \mathrm{Na} & 14.0 & 8.1 & 29.0 & 20.0 & 4.3 \\ \mathrm{~K} & 3.4 & 2.0 & 3.3 & 5.9 & 25.4 \\ \mathrm{Cl} & 17.0 & 10.0 & 33.0 & 27.0 & 78.3 \\ \mathrm{SO}_{4} & 57.0 & 26.0 & 120.0 & 108.0 & \\ & \text { Distance from Mount St. Helens } & \end{array}$

\section{Precipitation Data}

Precipitation was an important factor in lake dilution rates and influences dissolved ion concentrations in the lakes. Precipitation was measured within the blast zone by a network of precipitation gauges throughout the Mount st. Helens area and monitored by a variety of agencies. While gauges were not established within individual lake basins, annual precipitation at each lake was estimated by linear regression of precipitation on elevation (Alan Donner, U.S. Army Corps of Engineers, personal communication). 
Ions in precipitation originate from a variety of sources, including oceanic spray, terrestrial dust, atmospheric gases, and volcanic emissions. Berner and Berner (1987) reported average concentrations of ions in precipitation over the United States. Approximate concentrations of ions in precipitation for the Mount st. Helens area were determined using Berner and Berner's (1987) data (Table IV).

TABLE IV

AVERAGE ION CONCENTRATIONS IN PRECIPITATION

(Concentrations In $\mathrm{mg} / \mathrm{L}$ )

\begin{tabular}{lc} 
Ion & Concentration \\
\hline $\mathrm{Ca}$ & 0.3 \\
$\mathrm{Mg}$ & 0.05 \\
$\mathrm{Na}$ & 0.6 \\
$\mathrm{~K}$ & 0.2 \\
$\mathrm{Cl}$ & 0.6 \\
$\mathrm{SO}_{4}$ & 0.48
\end{tabular}

Values listed for calcium, sodium, potassium, and chloride were interpolated from maps of the United States showing concentration gradients. Magnesium concentration was estimated from calcium/magnesium weight ratios presented for the Pacific Northwest (Berner and Berner, 1987). The sulfate concentration was obtained from Nelson (1991) as part of an evaluation of Cascade Mountain lakes with regard to acid deposition. While ions in precipitation were important, their concentrations were minor compared to ion concentrations leached from ash (see Table III). 


\section{CHAPTER III}

EXPERIMENTAL

\section{MATERIALS}

\section{Water}

Deionized water was used to prepare all solutions and wash equipment and glassware. Tap water was distilled and passed through a Barnstead NANOpure II Water system, consisting of an organic removal cartridge, two ion exchange cartridges, and a submicron bacterial removal filter.

\section{Acid Baths/Cleaning Protocol}

All containers and glassware were washed in warm tap water with standard laboratory soap (Labtone or Sparkleen), rinsed seven times each with tap water and deionized water, and placed into either a $4 \% \mathrm{HCl}$ bath or a $4 \% \mathrm{HNO}_{3}$ bath for a minimum 24 hours. The hydrochloric acid bath was used for all glassware except that used for anion analysis, since chloride might have contaminated the glassware. After the acid bath, the equipment was rinsed seven times with deionized water and placed in a dust-free environment to air dry. Sample storage containers (Nalgene) were not air dried. They were capped after rinsing, and thoroughly rinsed in the field prior to filling with sample. 
METHODS

\section{Sampling}

Most lakes were sampled three times in 1993 and once during the summer of 1994. Sampling during 1993 occurred in spring, after turnover, in summer, during thermal stratification, and in the fall (Table V).

\section{TABLE V}

SAMPLING DATES FOR 1993 AND 1994

\begin{tabular}{lclcc} 
Lake & Spring & $\begin{array}{l}1993 \\
\text { Summer }\end{array}$ & $\frac{\text { Fall }}{\mathrm{X}}$ & $\begin{array}{c}1994 \\
\text { Summer }\end{array}$ \\
Panhandle & $\mathrm{X}$ & $08 / 14$ & $07 / 19$ \\
Boot & $\mathrm{X}$ & $08 / 15$ & $\mathrm{X}$ & $07 / 21$ \\
Fawn & $05 / 22$ & $08 / 05$ & $10 / 02$ & $\mathrm{X}$ \\
Hanaford & $05 / 22$ & $08 / 05$ & $10 / 02$ & $\mathrm{X}$ \\
Ryan & $06 / 17$ & $08 / 24$ & $10 / 09$ & $\mathrm{X}$ \\
St. Helens & $\mathrm{X}$ & $08 / 10$ & $\mathrm{X}$ & $07 / 18$ \\
Venus & $\mathrm{X}$ & $08 / 09$ & $\mathrm{X}$ & $\mathrm{X}$ \\
Castle & $06 / 26$ & $09 / 17$ & $\mathrm{X}$ & $\mathrm{X}$ \\
Coldwater & $03 / 24$ & $08 / 04$ & $10 / 02$ & $\mathrm{X}$ \\
June & $05 / 29$ & $09 / 09$ & $10 / 17$ & $\mathrm{X}$ \\
McBride & $05 / 29$ & $09 / 09$ & $10 / 17$ & $\mathrm{X}$ \\
Merrill & $04 / 17$ & $09 / 08$ & $10 / 16$ & $\mathrm{X}$ \\
\multicolumn{1}{c}{$\mathrm{X}=$ No sampling was } & performed & &
\end{tabular}

Lakes which were inaccessible due to late spring or early fall snowfalls were sampled only when accessible. Other lakes, which are accessible only by helicopter, where sampled during times of helicopter availability. Sampling during the summer of 1994 was less frequent because the lakes were accessible only by helicopter, and forest fires made helicopters unavailable.

During each trip, temperature profiles for each lake were recorded to determine sampling locations. Samples were 
taken from the epilimion (usually 1 meter) "metalimnion, and hypolimnion. On several occasions replicate samples were obtained from each depth. For several lakes, samples were collected at two stations to assess spatial homogeneity.

Water samples were collected using a $2.5 \mathrm{~L}$ scott bottle. The acid-washed high density linear polyethylene (HDLP) sample bottles were rinsed three times with sample water and filled; one $500 \mathrm{~mL}$ bottle was filled for ion analyses (occasionally two 250 milliliter bottles were used - one each for cations and anions), one $250 \mathrm{~mL}$ bottle was filled for alkalinity and conductivity analyses, and one 250 mL bottle was filled for phytoplankton analysis.

Samples for identification and enumeration of phytoplankton were preserved by adding Lugol's solution to make a 18 solution. Vertical plankton tows for identification and enumeration of zooplankton were performed at various depths, generally sampling the epilimnion, metalimnion, and hypolimnion. Samples were stored in $250 \mathrm{~mL}$ HDLP bottles and preserved by adding formaldehyde to make a 5\% solution. The net used for plankton tows had a mesh size of $130 \mu \mathrm{m}$, with a $30 \mathrm{~cm}$ mouth and a 5:1 scope ratio. Laboratory Procedures

Conductivity. Conductivity was determined using a Wheatstone bridge circuit and cell, which can measure conductance with a high degree a accuracy and precision 
(Skoog, 1985). Sample conductivity was measured with a YSI Model 31 Conductivity Bridge and a YSI $3403 \mathrm{Cell}$ at $25^{\circ} \mathrm{C}$. Constant temperature was attained by equilibration in a Blue M Electric Company MagniWhril constant temperature bath. After each measurement the cell was thoroughly rinsed with deionized water.

Quality assurance was monitored by comparison of experimental conductivity measurements with conductivities calculated from ion concentrations. Comparison of values obtained indicated agreement to within 15\%. Larger percent differences were anticipated since any charged species contributes to the total conductance of a solution.

Alkalinity/Bicarbonate Ion. The Gran plot titration was used for the determination of alkalinity as described in Wetzel and Likens (1991). In most natural waters, borate, ionized silicic acid, bisulfate, and organic anions are present in small quantities compared to the bicarbonate and carbonate ion concentrations. At normal $\mathrm{pH}$ values of the study lakes, bicarbonate was the dominant species in the carbonate equilibrium system, and the alkalinity was a result of the bicarbonate ion.

Cations. Major cations were analyzed by direct aspiration atomic absorption spectrophotometry (AAS) as described by the United States Environmental Protection Agency (1979) using a Perkin-Elmer 305B Atomic Absorption Spectrophotometer with Intensitron Hollow Cathode Lamps. 
AAS has proven to be a fast method of analysis that produces highly accurate results, free from interferences (skoog, 1985). Instrument parameters for the analysis varied for each cation analyzed (Table VI).

\section{TABLE VI \\ Instrument Parameters For Cation \\ Analysis By Atomic Absorption \\ Spectrophotometry}

$\begin{array}{lllll} & \text { Sodium } & \text { Potassium Calcium } & \text { Magnesium } \\ \text { Sensitivity(mg/L) } & 0.015 & 0.04 & 0.08 & 0.007 \\ \text { Detec Limit(mg/L) } & 0.002 & 0.1 & 0.01 & 0.001 \\ \text { Wavelength(nm) } & 589.6 & 766.5 & 422.7 & 285.2 \\ \text { Fuel } & \text { Acetylene Acetylene Acetylene Acetylene } \\ \text { Oxidant } & \text { Air } & \text { Air } & \text { Air } & \text { Air }\end{array}$

Standard curves were prepared by diluting J.T. Baker Inc. Atomic Absorption standard Solutions $(1000 \mu \mathrm{g} / \mathrm{mL})$ with deionized water. Lanthanum chloride solution ( $1 \mathrm{~mL} \mathrm{LaCl}_{3}$ per $10 \mathrm{~mL}$ of sample) was added to each sample for calcium and magnesium analysis. Lanthanum solution was added as a releasing agent for cation solutions (Skoog, 1985).

Cation concentrations were determined using the standard curve technique for quantitative analysis. Matrix effects can cause erroneous results, therefore, 29 samples were analyzed by the known addition method as well. Percent differences were calculated between the two methods (Appendix C). Variations in the percent difference indicated matrix effects were minimal or absent. Quality assurance tests included comparison of results 
obtained from standard curve and known addition techniques, comparison of replicated lake water samples, as well as analysis of solutions containing cation concentrations unknown to the analyst. True concentrations of the "unknown" solutions, concentration values obtained by each technique, and percent differences for each were reported (Appendix D). The relatively small percent differences in values obtained by standard curve and known addition indicated the analytical methodologies were reliable. Values obtained in replicated samples agreed to within $5 \%$. Comparison of experimental values with true values for the unknown solutions agreed to within $10 \%$.

Anions, Chloride and sulfate were analyzed by ion chromatography (IC). IC is highly sensitive and enables the ions to be separated from the matrix, preventing interferences (Skoog, 1985). The IC instrument was a Dionex $2010 i$ Ion Chromatograph equipped with a HPIC-AG4 guard column, a HPIC-AS4 separator column, and a ASC-1 anion suppressor column using a $0.025 \mathrm{M} \mathrm{H}_{2} \mathrm{SO}_{4}$ suppressor solution (Table VII). The instrument had a conductivity detector and the output was recorded on a Iinear 1200 strip chart recorder.

Samples were injected into the chromatograph with Becton Dickinson \& Company Precisionglide 5cc syringes. syringes were rinsed thoroughly three times each with deionized water and sample solution prior to injection. 
Anion concentrations were determined from peak heights using the standard curve technique. Solutions for analysis by standard curve were prepared by diluting E.M. Science Chloride $(1.000 \pm 0.002 \mathrm{~g} / \mathrm{L})$ and sulfate $(1.000 \pm 0.002 \mathrm{~g} / \mathrm{L})$ standard Solutions with deionized water.

\section{TABLE VII}

Instrument Parameters For Anion Analys is By Ion Chromatography

$\begin{array}{ll}\text { Eluent } & 0.0028 \mathrm{M} \mathrm{NaHCO} \\ & 0.0022 \mathrm{M} \mathrm{Na} \mathrm{CO}_{3} \\ \text { Flow Rate } & 1.4 \mathrm{~mL} / \mathrm{min} \\ \text { Pressure } & 620 \mathrm{psi} \\ \text { Chart Speed } & 1 \mathrm{~cm} / \mathrm{min} \\ \text { Retention Time } & \mathrm{Cl}^{-} \mathrm{p} 2.5 \mathrm{~min} \\ & \mathrm{SO}_{4}{ }^{2-\mathrm{p} 9.0 \mathrm{~min}} \\ \text { Output Range } & 10 \mu \mathrm{S}\end{array}$

Quality assurance was monitored by comparison of results obtained from replicated samples of lake water. Comparison of values obtained for replicated samples indicated they agreed to within $5 \%$. 
CHAPTER IV

RESULTS

ANALYSIS OF CHEMICAL DATA

\section{Current study}

A comprehensive listing of chemical data collected from all 12 lakes in this study for both 1993 and 1994 were presented (Appendix E). The simplest method for analysis of processes occurring within the lakes was by comparison of data obtained for all three sample periods. Thermal stratification, determined from temperature profiles (Appendix F), has little affect on ionic concentrations during the summer, although there was likely to be some diffusion and slight mixing of water between the hypolimnion and epilimnion. Comparison of summer data with those obtained after spring and fall turnover afforded the opportunity for determining hydrological processes occurring in the lakes. For those lakes which samples were not collected during spring or fall, analyses was somewhat 1 imited.

Panhandle, Boot, st. Helens, and Venus. Panhandle, Boot, and st. Helens Lakes were sampled in the summers of both 1993 and 1994. Venus Lake was sampled only in the summer of 1993. Domination by $\mathrm{Ca}-\mathrm{SO}_{4}$ was evident in all 
four lakes. The data indicated concentration gradients with depth for all jons measured in the lakes. Without data from the spring or fall from both sample seasons, conclusions as to the concentration gradients can only be assumed. Possible scenarios which would have accounted for the gradients could be: (1) High ionic concentration groundwater could have entered the hypolimnion, increasing concentrations in the hypolimnion, while epilimnetic concentrations decreased as a result of direct precipitation and outflow of more concentrated water; (2) Low ionic concentration runoff could have entered the epilimnion, decreasing concentrations; while the hypolimnion remains unaffected; (3) Runoff could have entered the epilimnion, decreasing concentrations, while hypolimnetic concentrations increased as a result of dissolution or ion exchange reactions with the sediment.

Fawn. Data obtained during 1993 for Fawn Lake, dominated by $\mathrm{Ca}-\mathrm{SO}_{4} / \mathrm{HCO}_{3}$, indicated sampling occurred near spring turnover as ionic concentrations varied only slightly with depth. The temperature profile showed slight thermal stratification. Surface temperature was $11^{\circ} \mathrm{C}$ and the temperature at $20 \mathrm{~m}$ was $5^{\circ} \mathrm{C}$. Epilimnetic concentrations decreased through the year, which suggested dilution of ion concentrations as a result of lower ionic concentration runoff. Hypolimnetic concentrations increased due to the dissolution of, or ion exchange reactions with, the 
sediment; or possible seepage of more concentrated groundwater. Metalimnetic concentrations increased slightly through the year as a result of diffusion from the higher concentration hypolimnion.

Hanaford. Hanaford Lake, which was dominated by Ca$\mathrm{SO}_{4}$, was sampled three times during 1993. The spring sample did not show marked differences in ion concentrations with depth. Stratification was beginning with $10.9^{\circ}$ and $5.4^{\circ} \mathrm{C}$ at the surface and $16 \mathrm{~m}$, respectively. Decreased epilimnion and metalimnion ion concentrations were observed in the summer as a result of dilution from runoff; while increased hypolimnetic concentrations from interactions with the sediment or groundwater seepage was apparent, Fall samples for Hanaford Lake were collected after turnover, as evident by the temperature profile; $14^{\circ}$ and $11.5^{\circ} \mathrm{C}$ at the surface and $14 \mathrm{~m}$, respectively. Ion concentrations increased throughout the vertical profile from summer to fall. Epilimnetic concentrations may have increased as a result of deep mixing with high concentration hypolimnetic water, or from high-concentration runoff from increased autumnal precipitation. Further increases were observed for the hypolimnion as a result of continued interaction with the sediments or groundwater seeps.

Ryan. Spring and summer data for Ryan Lake show little variation in ionic concentrations in the epilimnion and metalimnion, with higher hypolimnetic concentrations. A 
slight increase in concentrations from spring to summer was observed. High hypolimnetic concentrations for spring and summer could have been a result of interactions with the sediment or groundwater seeps. Fall samples were probably collected near turnover (from the temperature profile), as there was little variation in the temperature profile. This hypothesis was supported by increased epilimnion and metalimnion ion concentrations from summer to fall, with decreased hypolimnetic concentrations from summer to fall.

Castle. Castle Lake, which was inaccessible during the fall of 1993, was dominated by $\mathrm{Ca}^{-} \mathrm{HCO}_{3}$. Spring sampling, which occurred late in the season (26 June 1993) after turnover as thermal stratification was established $\left(16.5^{\circ}\right.$ and $5.0^{\circ} \mathrm{C}$ at the surface and $30 \mathrm{~m}$, respectively). Epilimnetic concentrations were lower than in the hypolimnion. Comparison with summer data, which most likely occurred prior to fall turnover (the same temperature profile as spring was recorded for summer), indicated epilimnion and hypolimnion ion concentrations increased through the year, while metalimnetic concentrations remained the same.

Lower spring epilimnetic concentrations may have been due to precipitation and runoff diluting the epilimnion; while low summer precipitation, which was common for the region, may have caused evaporative concentration of epilimnetic ions. The increase noted in the hypolimnion may 
have been a result of chemical interactions with the sediment or groundwater seeps. This was supported by data from samples taken closer to the sediment (station 1), which showed higher ion concentrations.

Coldwater. Coldwater Lake, which was dominated by Ca$\mathrm{SO}_{4} / \mathrm{HCO}_{3}$, was sampled three times during 1993. Spring data indicated no epilimnion and hypolimnion ion concentration differences. Summer data showed concentrations had decreased in the epilimnion and metalimnion, with no hypolimnetic concentration changes. As the spring samples were taken early in the season, spring and early summer precipitation and runoff are the most probable reason for the dilution observed. Fall data, which was obtained after turnover, indicated concentration gradients were present, but levels in the epilimnion and metalimnion had increased. Hypolimnetic concentrations remained constant throughout the season. Increases in the epilimnion and metalimnion were a result of turnover, but values lower than those of the hypolimnion were expected as a result of dilution from increased autumnal precipitation.

June. June Lake, which is an extremely shallow lake $\left(\mathrm{Z}_{\operatorname{Max}}=1.5 \mathrm{~m}\right)$ dominated by $\mathrm{Na}-\mathrm{HCO}_{3}$, was sampled three times during 1993. Due to the depth of the lake, two samples were taken during the spring. Both samples suggested the lake was well mixed. Only one sample was required for summer and fall, as temperature profiles indicated no thermal 
stratification. Ionic concentrations increased during summer then decreased in fall. During the summer, the lake may have undergone evaporative concentration as a result of decreased precipitation and the small lake volume. As autumnal precipitation increased, ion concentrations decreased due to dilution from increased lake volume.

McBride. McBride Lake, like June Lake, is an extremely shallow lake $\left(Z_{\max }=2 \mathrm{~m}\right)$ which did not stratify during 1993 . MCBride Lake was dominated by $\mathrm{Ca} / \mathrm{Na}-\mathrm{HCO}_{3}$. Replicate samples at two depths were taken during the spring. Analysis showed ionic concentrations did not differ and the lake was well mixed. Temperature profiles indicated one sample, at the surface, was adequate to obtain the required information from the summer and fall samples. Like June Lake, McBride underwent evaporative concentration during summer; although concentrations continued to increase through fall.

Merrill. Merrill Lake, dominated by $\mathrm{Ca}-\mathrm{HCO}_{3}$, was sampled three times during 1993. Ion concentrations of samples collected during the spring did not vary with depth, which indicated spring turnover had thoroughly mixed the lake. The temperature profile in spring ranged from $7.5^{\circ} \mathrm{C}$ at the surface to $6.0^{\circ} \mathrm{C}$ at 17 meters. Merrill Lake was slightly deeper than some of the other lakes in this study, and stratification was apparent during summer sampling. Fall sampling occurred near fall turnover as the temperature profile (recorded to 9 meters) was isothermal at $14.7^{\circ} \mathrm{C}$. 
Merrill lake functioned as would be expected for an undisturbed system. There were no alterations in ionic concentrations, spatially or temporally.

Trends In The Chemical Data

Unaffected "Control" Lakes. In general, substantial data does not exist to indicate that June, McBride; or Merrill Lakes underwent appreciable, long-term physical changes. There were no changes in area, volume, configuration, or profile of these lakes, and no physical changes would be expected.

No pre-eruption data on these lakes is available, so post-eruption concentrations could not be compared with true "baseline" data. For this reason, data obtained on "control" lakes could not be used as baseline values, rather they could be used to compare with values obtained for affected lakes.

All three lakes appear to have been similar in that there were no clear trends in ion chemistry. If the lakes were impacted by the eruption, it would be expected that a decline in the concentrations of all ions from 1980 to 1993 would have been observed. Ion concentrations appeared to fluxuate from 1980 to 1993. These fluxuations were accounted for by comparing total cation concentrations with precipitation data (Figure 3). As the amount of annual precipitation increased or decreased, ion concentrations were affected inversely. 
Figure 3. Precipitation Effect On Control Lakes

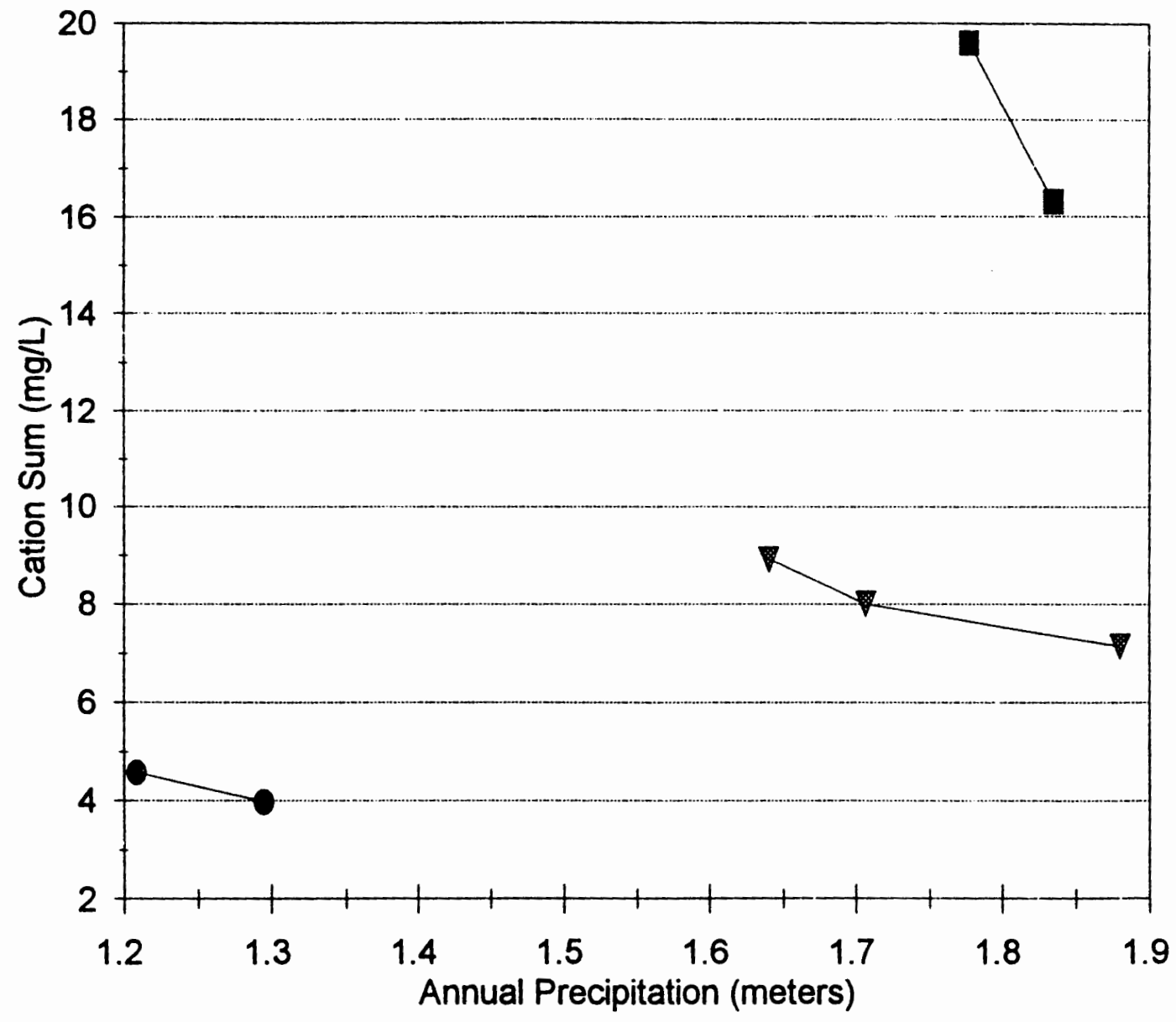

- June $\quad$-McBride - Merrill 
Comparison of data for the control lakes with that of other lakes located in the south washington Cascade Mountains (Landers, et al., 1987) indicated Merrj.11 Lake had similar ion concentrations to the regional mean. June and McBride Lakes had higher concentrations of calcium, magnesium, and potassium than the regional mean. compared to regional mean concentrations, sodium was four times as concentrated in McBride Lake, and fourteen times as concentrated in June Lake.

The only apparent data discrepancy was the alkalinity of McBride Lake. The alkalinity increased from 146 in 1980 to $412 \mu \mathrm{eq} / \mathrm{L}$ in 1993 . The cation to anion ratio for 1993 data was 0.953 , while the ratio for 1980 was 1.278 . A calculated value of $250 \mu \mathrm{eq} / \mathrm{L}$ for the 1980 alkalinity provided a ratio of 0.952 ; therefore, the alkalinity value reported for 1980 may have been too low.

Lakes Affected By The Eruption. of the lakes affected by the eruption, Fawn and Hanaford Lakes showed the highest ion concentrations after the eruption. Although they were farthest from the volcano, 15 and $14 \mathrm{~km}$, respectively; they were not shielded from the blast and they had smaller volumes than most of the other lakes. Ryan, Boot, and Panhandle Lakes contained lower initial concentrations of ions, because they were less exposed to the blast by mountain ridges. Venus and st. Helens Lakes contained the lowest initial concentrations of ions of all the affected 
lakes following the blast, probably as a result of their large volumes. The effect of lake volume on ion concentration initially after the blast was noted by an exponential decrease in total ion concentration as a function of lake volume (Figure 4).

Although it would be expected that distance from the crater would play a role in the initial ion concentrations in the lakes, no correlation was detected (Figure 5). This was likely a result of extreme variations in regional topography

Ion concentrations continued to decline from the initial 1980 values through 1993 and 1994, with few minor exceptions. The only noticeable exception was observed in the calcium data for Fawn Lake. The calcium concentration increased from $8.66 \mathrm{mg} / \mathrm{L}$ in 1991 to $10.23 \mathrm{mg} / \mathrm{L}$ in 1993 . It was possible that one of the values is erroneous, as other cation concentrations continued to decrease from 1991 to 1993. The cation to anion balance for the 1993 data resulted in a ratio of 0.972 , indicating the calcium concentration reported for $1991(8.66 \mathrm{mg} / \mathrm{L})$ was likely the erroneous value.

Data reported for 1991 (Petersen, 1993) and 1993 indicated ion concentrations for Fawn and Hanaford Lakes showed the greatest decline. Fawn and Hanaford Lakes are shallow lakes which received high inputs of ions from the eruption. Boot, Panhandle, and Ryan Lakes declined at a 
Figure 4. Volume Effect On Control Lakes

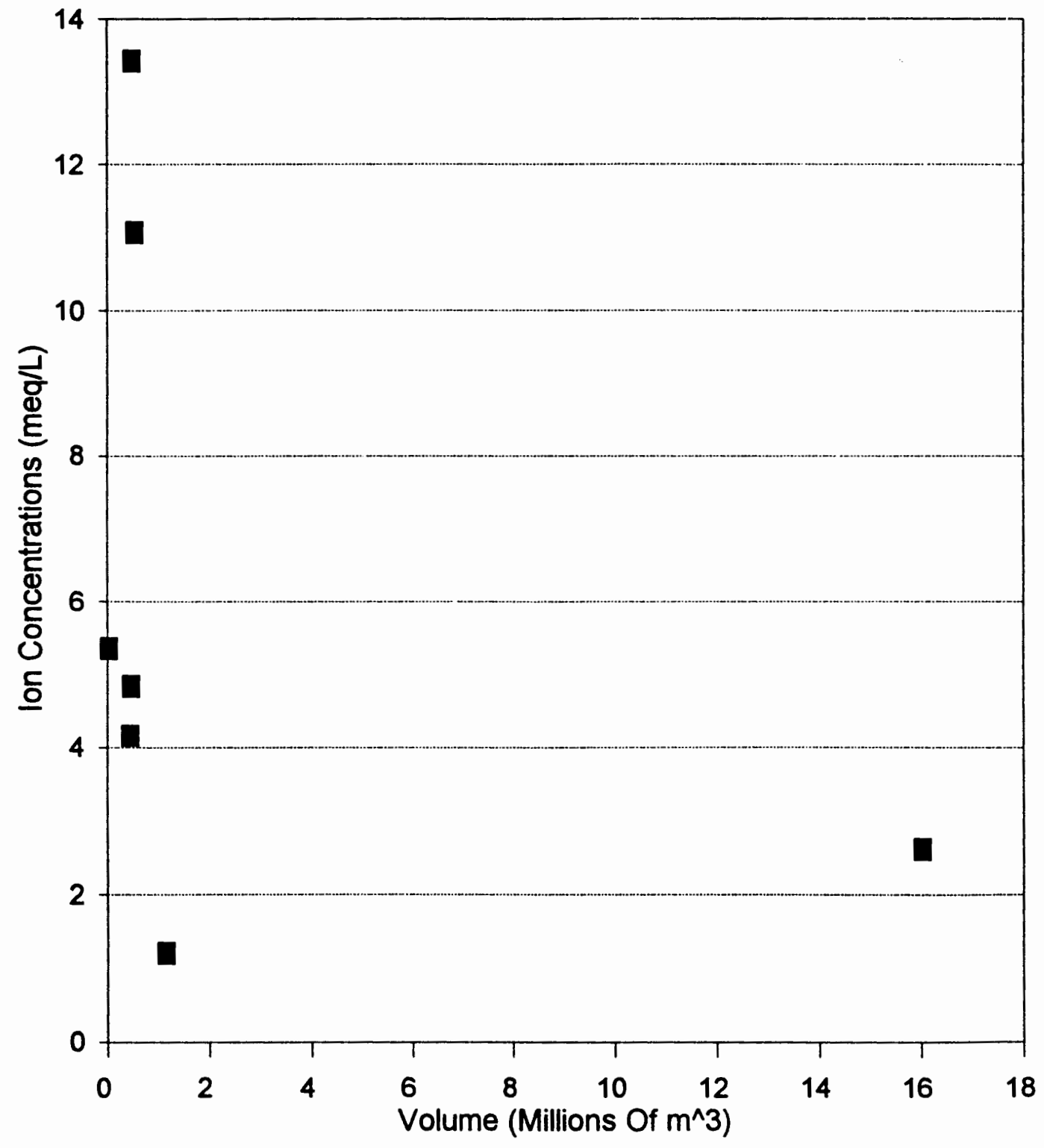


Figure 5. Distance Effect On Initial Concentrations

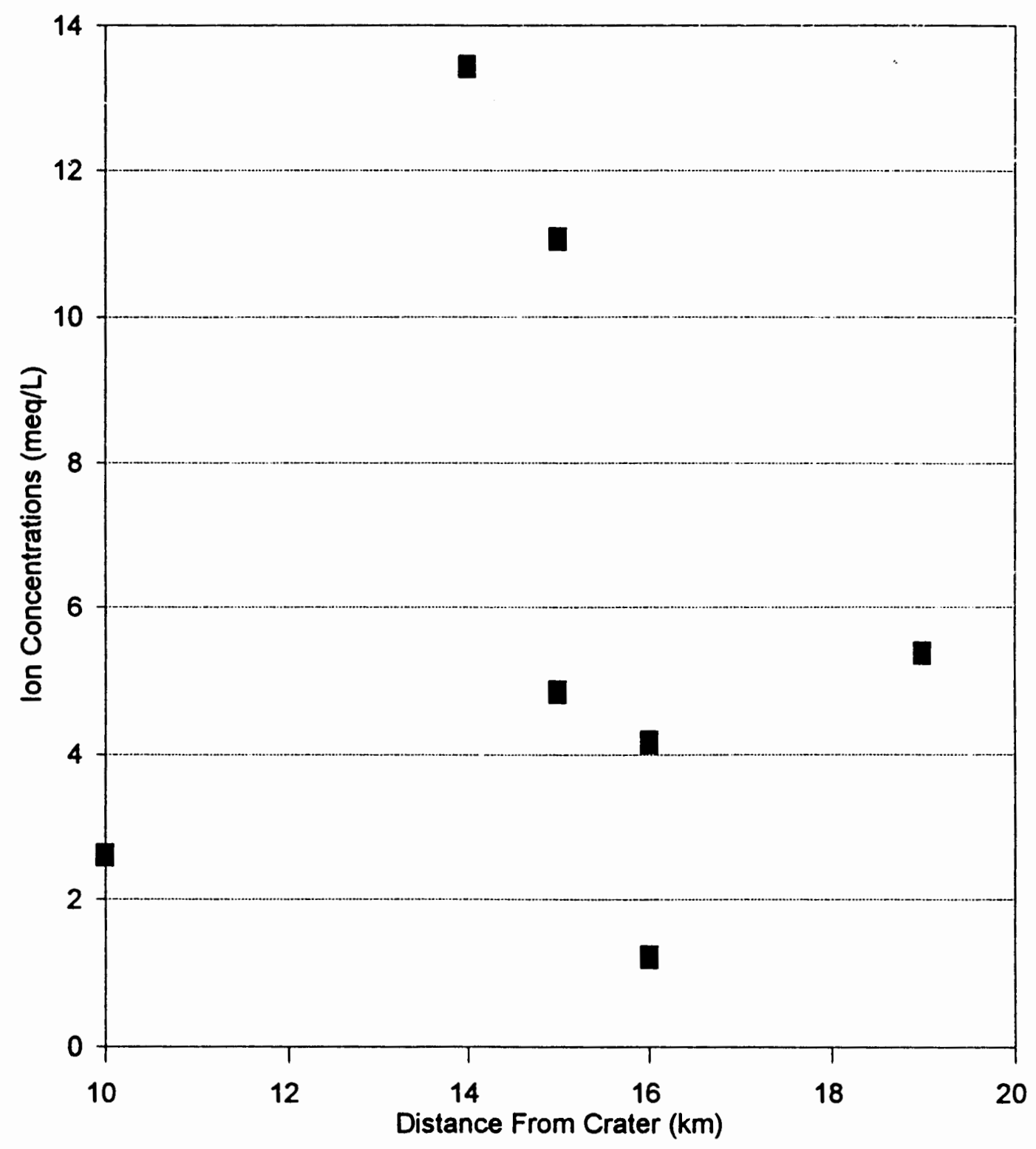


slower rate; and the two deepest lakes, Venus and st. Helens Lakes, showed the smallest decline in ion concentrations. Venus and st. Helens Lakes declined at the slowest rate as a result of their low initial ion concentrations and their large volume, which lead to high residence times and slower dilution.

The change in total ionic concentrations from 1980 to 1993 as a function of lake volumes (Figure 6), resulted in an exponential decline. This indicated lakes with large volume were slower at diluting ionic inputs from the eruption.

Lakes in the Mount st. Helens area were dominated by calcium and bicarbonate prior to the 1980 eruption (Collings, 1973 and Dion, et al., 1976). Dominance by calcium continued in all of the lakes through 1993, although sodium was a co-dominant cation in some of the lakes initially following the eruption. Dominance by calcium and sodium would be expected based upon their high weathering rates compared to magnesium and potassium. Panhandle, Hanaford, st. Helens, and Venus Lakes were dominated by calcium and sodium in 1980, with sodium concentrations declining to a greater extent than calcium, as calcium was more rapidly weathered than sodium.

The rapid weathering of sulfate from ash was reflected in post-eruption dominance by sulfate from 1980 through 1993 in all but two of the lakes. Exceptions include, Fawn and 
Figure 6. Change In lon Concentration

As A Result Of Lake Volumes




Ryan Lakes, which were dominated by both sulfate and bicarbonate in 1993 .

An explanation for the changes seen in the dominant ions was given by Embry and Dion (1988, p. 19):

The changes in the chemical water types of the lakes were largely a reflection of the composition of volcanic materials and debris introduced into the lakes at the time of eruption and the subsequent chemical and biological processes of the lakes.

The data indicated ion concentrations were at or below the concentrations measured in the control lakes. St. Helens, Fawn, and Hanaford Lakes had ion concentrations similar to McBride Lake, although calcium concentrations were twice as high as in McBride. Ryan Lake had ion concentrations similar to June Lake; although sodium levels were much lower in Ryan. Sodium concentrations in Ryan Lake were in the range of McBride and Merrill Lakes. Boot and Panhandle Lakes had ion concentrations near those of Merrill Lake, with the sodium concentration of Panhandle Lake lower than any control lake. Venus Lake had the same magnesium and potassium concentrations as those of McBride and Merrill Lakes. Calcium and sodium concentrations were below the levels in the control lakes.

Although ion concentrations in the blast zone lakes have declined to the levels in the control lakes, most remain at higher concentrations than the mean concentrations of the south Washington Cascade Mountain lakes. Panhandle, Boot, and Venus Lakes had calcium and magnesium 
concentrations slightly below those reported for the south Washington Cascade Mountain lakes; while sodium and potassium concentrations were slightly above. For Fawn, Hanaford, Ryan, and st. Helens Lakes, ion concentrations remained higher; calcium (2-3 times), magnesium (3-4 times), sodium (3-4 times), and potassium (2-10 times). Variations in lake ion concentrations, by comparison with the control lakes and the south Washington Cascade Mountain lakes, were a result of different ashfall patterns in lake basins and differences in ion weathering rates.

Normalized concentrations of the ions are significantly higher than predicted from theoretical dilution curves (Figures 7 through 11). Since dilution curves were plotted with the assumption that there was no ionic input from the precipitation or runoff, concentrations in excess of predicted values most likely resulted from precipitation and ash weathering input.

Differences from expected values reflected differences in weathering rates of the various ions from the ash. The greatest declines were observed in sodium and potassium, as a result of their lower weathering rate from the ash. Calcium and magnesium were easily weathered from the ash and have higher normalized values.

Panhandle, Boot, and Fawn Lakes all showed similar results, with normalized ion concentrations decreasing exponentially. The ion concentrations were approaching the 
Figure 7. Panhandle Lake

Dilution Model

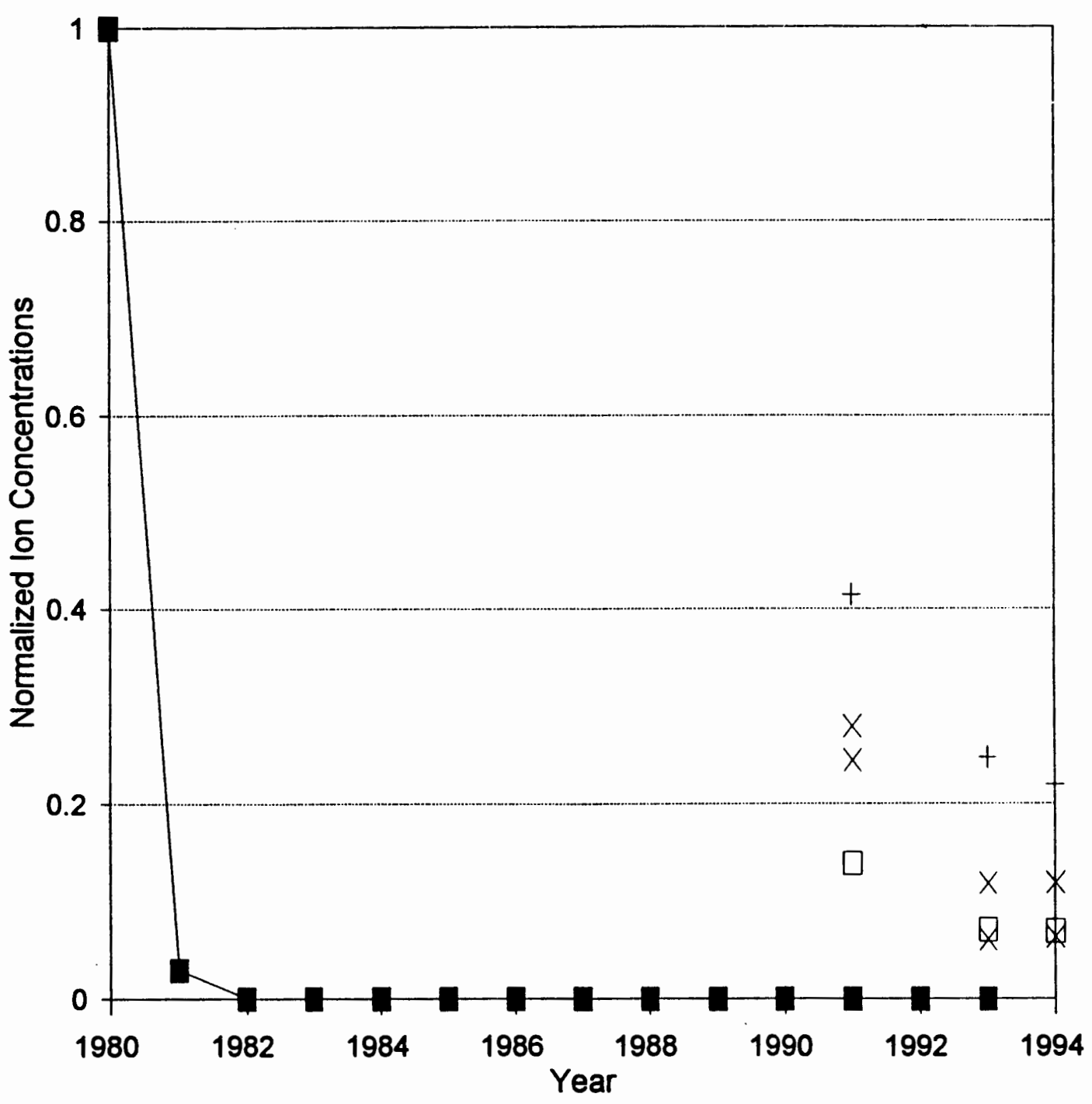

$-\mathrm{Ct} \times \mathrm{Ca}+\mathrm{Mg} \square \mathrm{Na} \times \mathrm{K}$ 
Figure 8. Bont Lake

Dilution Model

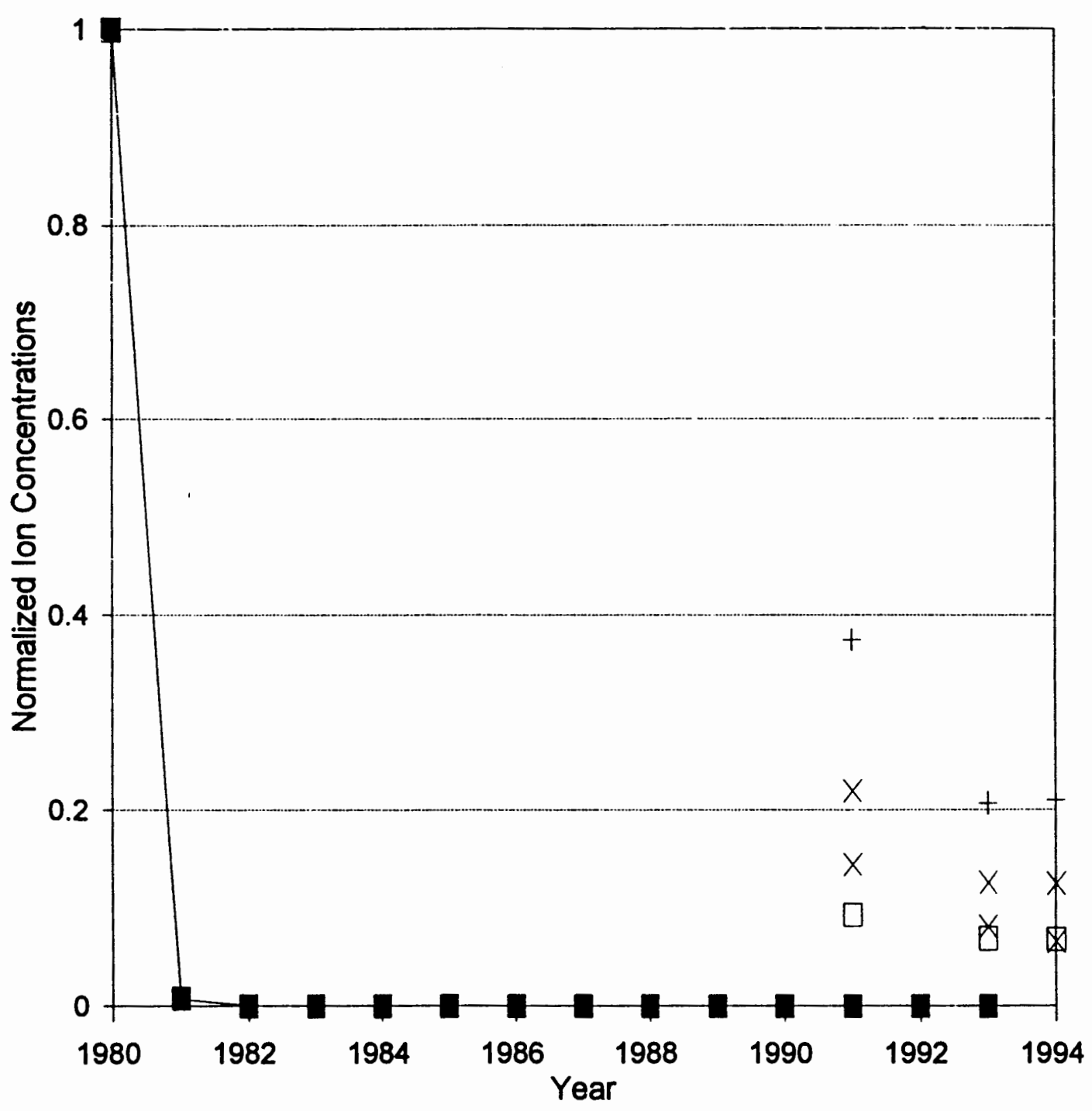

$+\mathrm{Ct} \times \mathrm{Ca}+\mathrm{Mg} \square \mathrm{Na} \times \mathrm{K}$ 
Figure 9. Fawn Lake

Dilution Model



$-\mathrm{Ct} \times \mathrm{Ca}+\mathrm{Mg} \square \mathrm{Na} \times \mathrm{K}$ 
Figure 10. St. Helens Lake

Dilution Model

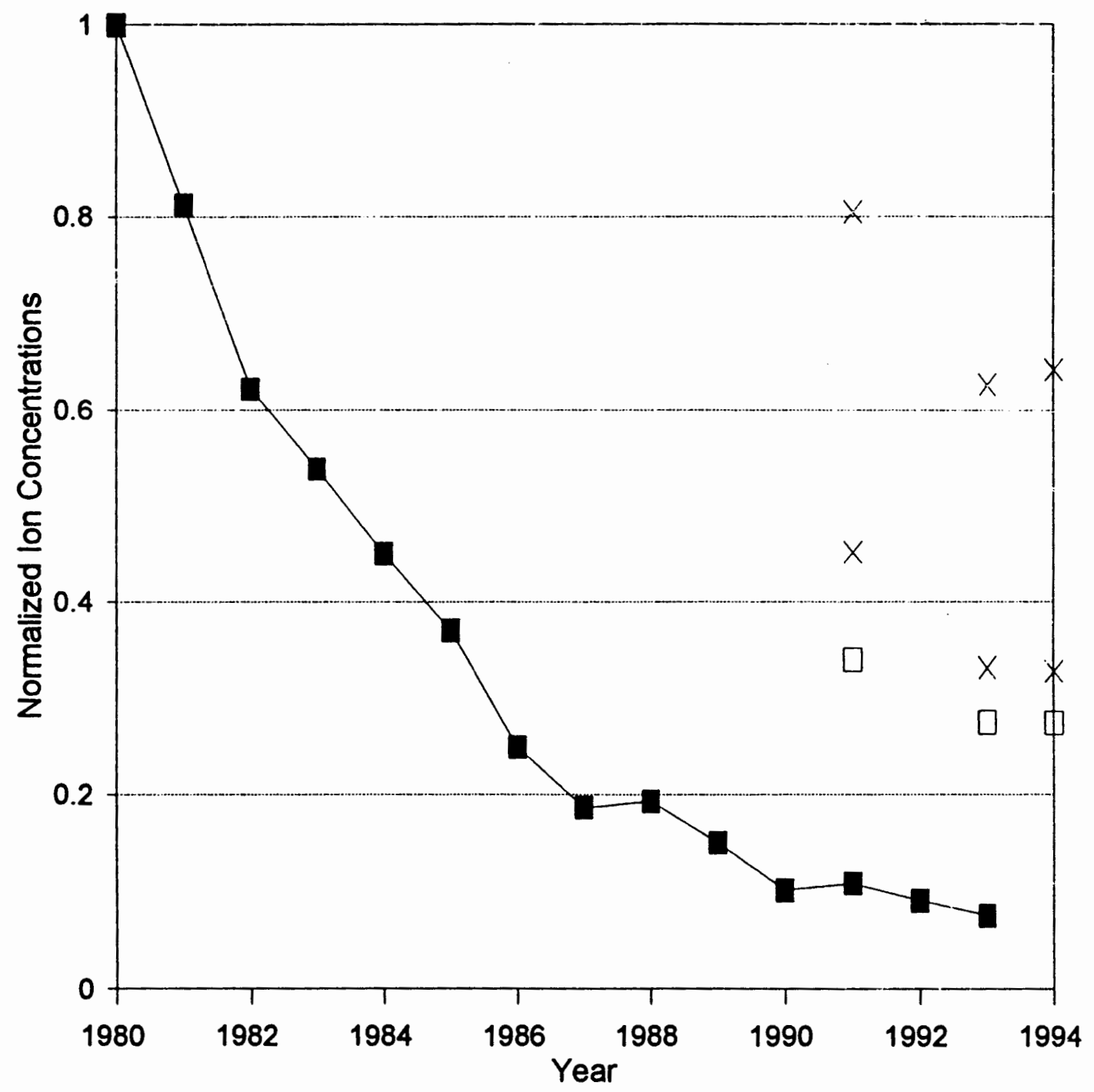

$-\mathrm{Ct} \times \mathrm{Ca}+\mathrm{Mg} \square \mathrm{Na} \times \mathrm{K}$ 
Figure 11. Venus Lake

Dilution Model

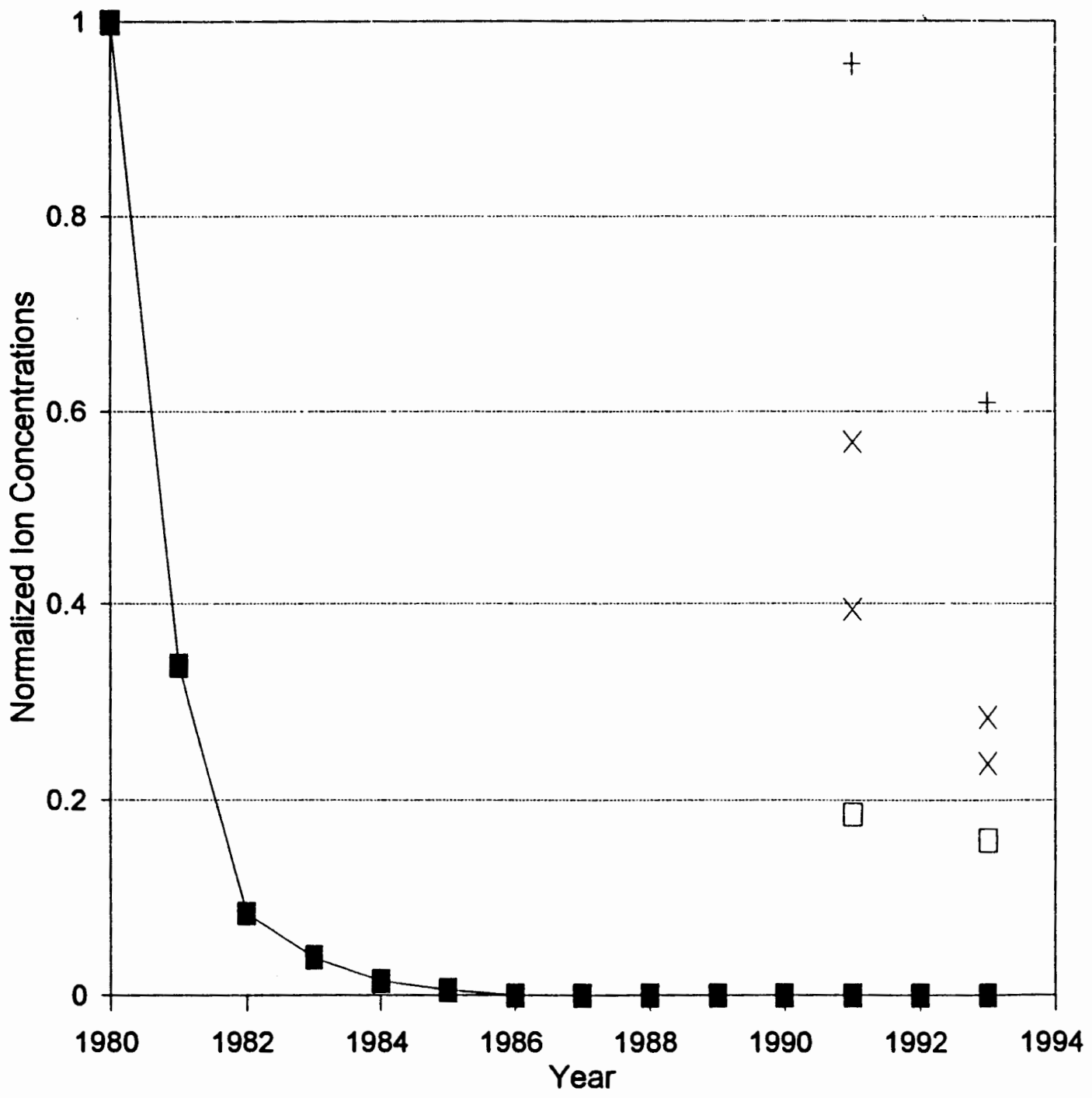

$-\mathrm{Ct} \times \mathrm{Ca}+\mathrm{Mg} \square \mathrm{Na} \times \mathrm{K}$ 
concentrations predicted by the dilution curves. St. Helens and Venus Lakes, on the other hand, had normalized ion concentrations which were much higher than predicted by dilution curves. As st. Helens and Venus Lakes received heavy ashfall and initial concentrations were low, the extent to which ash weathering subsequently affected ion concentrations was significant.

Lakes Formed By The Eruption. Ion concentrations in the summer of 1980 were highest in the newly formed, Castle and Coldwater Lakes. Castle and Coldwater Lakes underwent the largest relative decrease in ion concentrations. The lakes were only partly filled during the summer of 1980 (Petersen, 1993). Concentrations declined dramatically through the summer of 1984, largely due to dilution, as the lakes continued to fill. Castle lake continued to decline in ionic concentrations through the summer of 1993 . Changes in coldwater Lake were different from Castle Lake. Concentrations in Coldwater Lake increased between 1984 and 1989. This increase was due to the input of high ionic strength water from spirit Lake. Concentrations declined when the formation of the debris delta reduced inflow of water from spirit Lake into coldwater Lake.

Castle Lake had been dominated by $\mathrm{Ca} / \mathrm{Na}-\mathrm{HCO}_{3}$ since the eruption. Coldwater Lake was dominated by $\mathrm{Ca} / \mathrm{Na}-\mathrm{Cl} / \mathrm{SO}_{4} / \mathrm{HCO}_{3}$ in the summer of 1980 . However, in the summer of 1981 , calcium became the dominant cation and bicarbonate the 
dominant anion, altnough data for chloride and sulfate was lacking. Dominance by calcium continued until coldwater Lake received inputs of spirit Lake water. Spirit Lake water had elevated sodium concentrations (Larson and Glass, 1987); and sodium was the dominant cation in Coldwater Lake through the summer of 1989. Sulfate and bicarbonate; Ca$\mathrm{SO}_{4} / \mathrm{HCO}_{3}$ dominated in 1991 and 1993.

Both Castle and Coldwater Lakes had concentrations in the summer of 1980 which were two orders of magnitude higher than the control lakes. In 1982, after a reduction in the concentrations of Castle and coldwater Lakes, the difference for most ions was less than an order of magnitude compared to McBride Lake.

Castle Lake, in 1991, had sodium and potassium concentrations below June and McBride Lakes and near Merrill Lake. Magnesium concentrations were similar to June and McBride Lakes, but slightly higher than Merrill Lake. Calcium concentrations were twice that of June and McBride Lakes and four times that in Merrill. In 1993, potassium concentrations dropped below that in June Lake, but equalled McBride Lake. Sodium concentrations had reduced to below June and McBride Lakes, and magnesium was less than that in June Lake. Calcium concentrations remained higher than the concentrations observed in all three control lakes.

Coldwater Lake, in 1991, had concentrations higher than McBride and Merrill Lakes; but sodium, magnesium, and 
potassium concentrations were similar to June Lake, with magnesium and potassium concentrations lower than June lake. In 1993, calcium concentrations were approximately twice the control lakes. Magnesium, sodium, and potassium concentrations were near, or below, those of June and McBride Lakes.

The data indicated that castle and coldwater Lakes were approaching the concentrations of the control lakes. Comparison of ion concentrations from Castle and coldwater Lakes with mean ion concentrations of lakes in the south Washington Cascade Mountains (Landers, et al., 1987) indicated that both remain twice as concentrated as was typical for lakes in the region.

Theoretical dilution curves for castle and coldwater Lakes showed an exponential decline, while normalized ion concentrations were higher (Figures 12 and 13). Normalized ion concentrations were below the dilution curve during 1981 and 1982 as a result of rapid dilution while the lakes filled.

Normalized ion concentrations for Castle Lake show a smooth exponential decline with sodium and potassium, while calcium and magnesium remained higher. As stated earlier, this was a result of different ion weathering rates. Coldwater Lake showed similar patterns in the decline of normalized ion concentrations until 1984 when the normalized ion concentrations increased. The increase in 
Figure 12. Castle Lake

Dilution Model

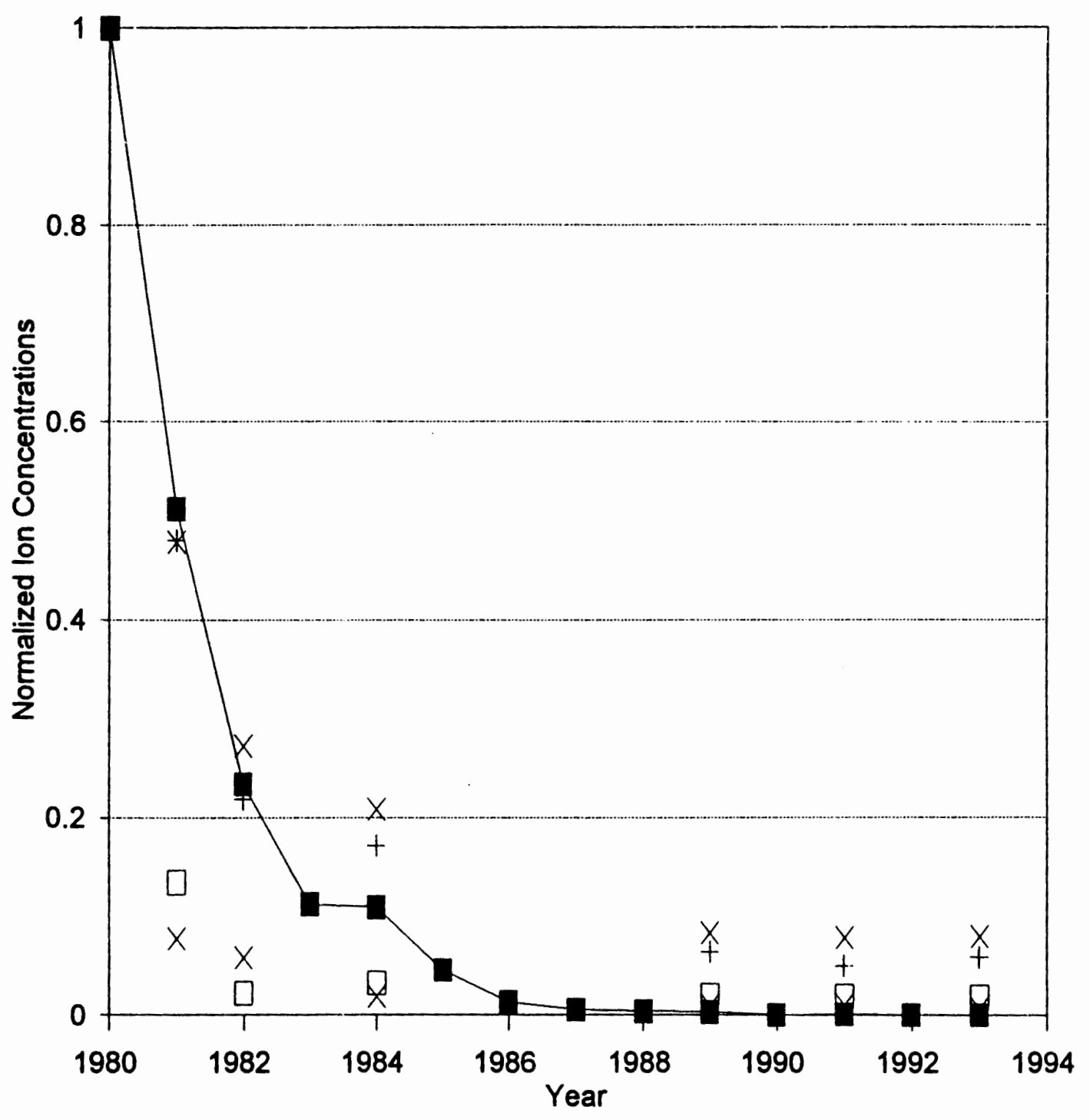

$-\mathrm{Cl} \times \mathrm{Ca}+\mathrm{Mg} \square \mathrm{Na} \times \mathrm{K}$ 
Figure 13. Coldwater Lake Dilution Model

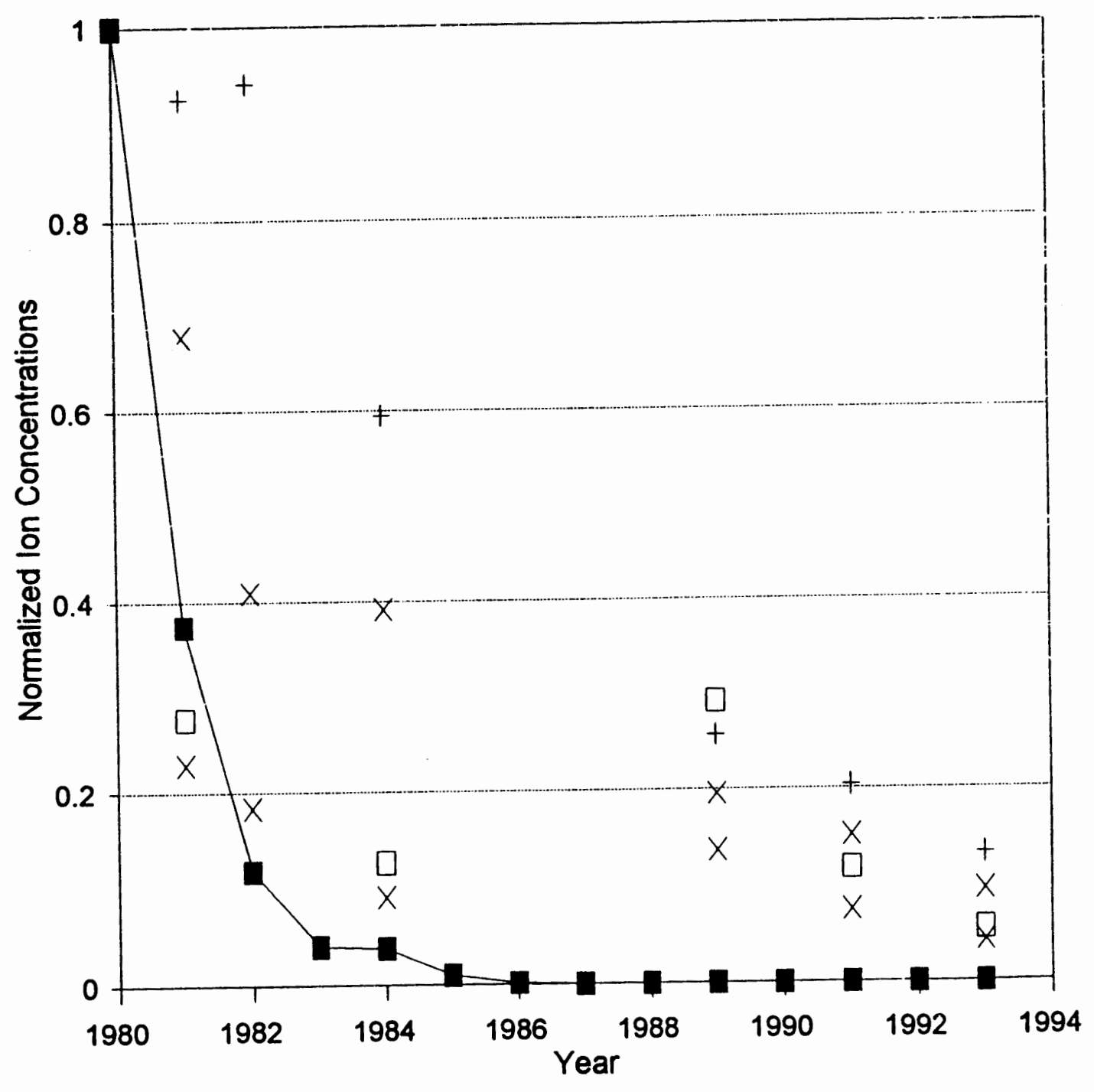

$-\mathrm{Ct} \times \mathrm{Ca}+\mathrm{Mg} \square \mathrm{Na} \times \mathrm{K}$ 
normalized ion concentrations was a result of the completion of the spirit lake pumping station and subsequent tunnel outlet. The most notable changes occur from 1984 to 1991 in the normalized concentrations of sodium and potassium. As the lake equilibrated with the influx of ions and the debris delta diverted much of the spirit Lake water, normalized ion concentrations declined exponentially.

Gibbs' Models. To further determine the mechanisms which control the ion chemistry of the study lakes and to analyze trends in the data, total dissolved solids (parts per million) versus the weight ratio $\mathrm{Na} /(\mathrm{Na}+\mathrm{Ca})$ were plotted on a revised Gibbs' model (Gibbs, 1992). In all lakes (Figures 14 through 16), rock weathering (ash in the lakes and basins) was the major mechanism controlling chemical composition, with contributions from high precipitation and runoff. The plots indicated the lakes were progressing toward dominance by calcium and bicarbonate. Total dissolved solids decreased in the lakes as a result of dilution. Decreased $\mathrm{Na} /(\mathrm{Na}+\mathrm{Ca})$ ratios were a result of more rapid weathering rate of calcium from the ash than sodium. Aside from st. Helens and Coldwater Lakes, the lakes appeared to be progressing at a similar rate. st. Helens Lake showed little change in total dissolved solids which was most likely a result of relatively small initial ion concentrations after the eruption. Coldwater Lake showed the expected decline in total dissolved solids, but the 
Figure 14. Gibbs Model - Part A

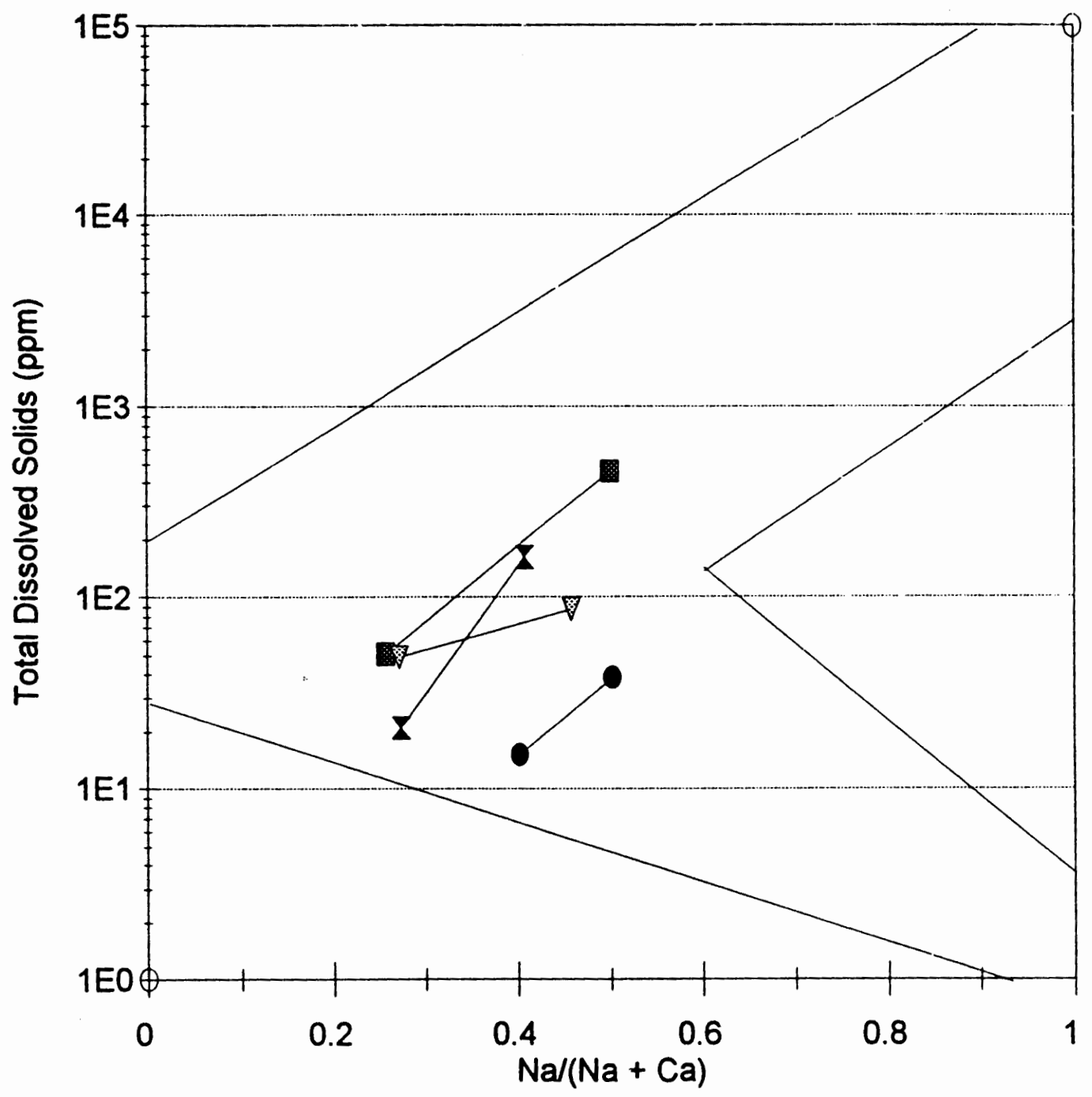

$\mathbf{x}$-Boot Hanaford $\rightarrow$ - Venus $\rightarrow$ StHelens 
Figure 15. Gibbs Model - Part B

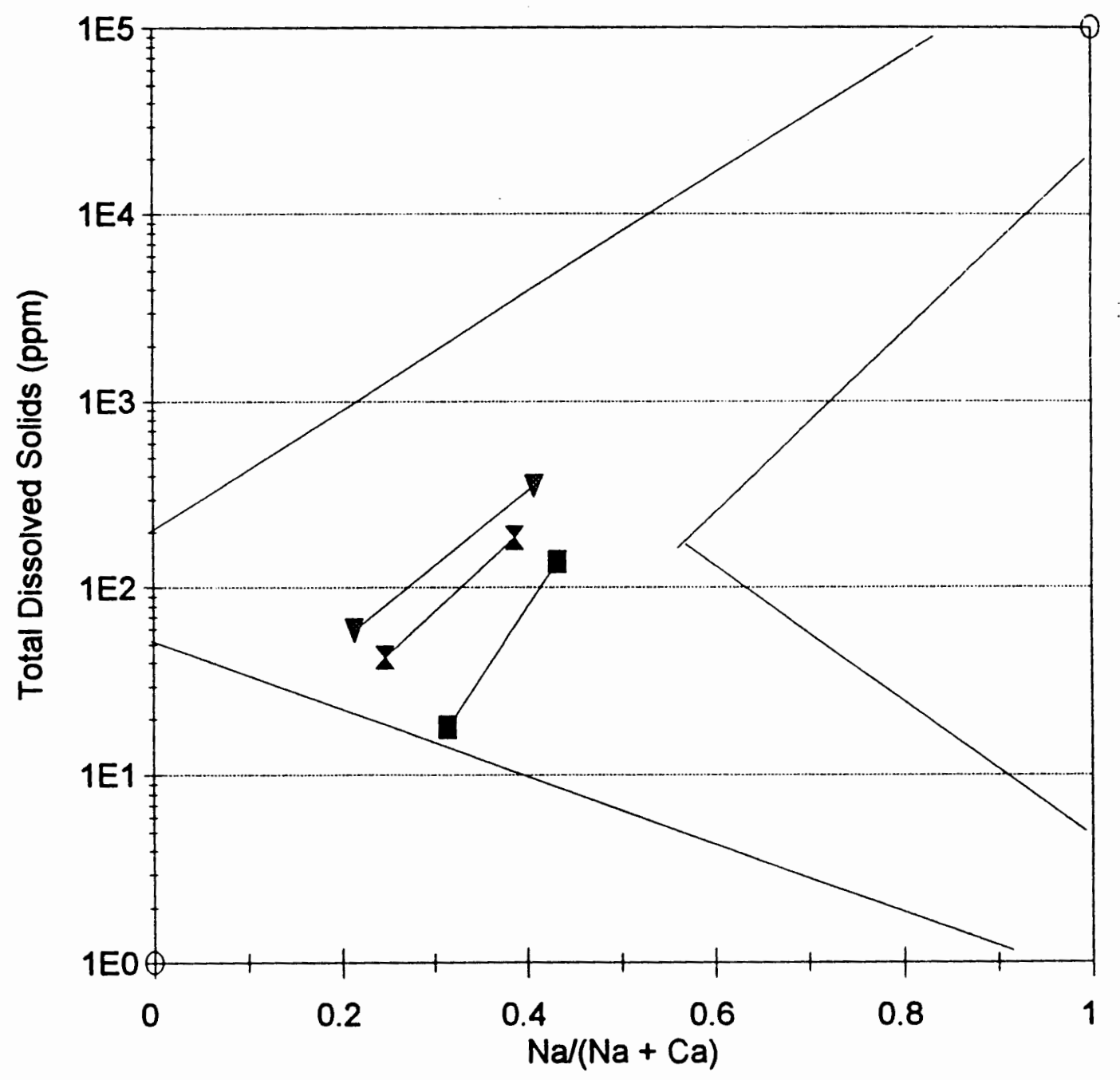

\section{Panhandle - Fawn I-Ryan}




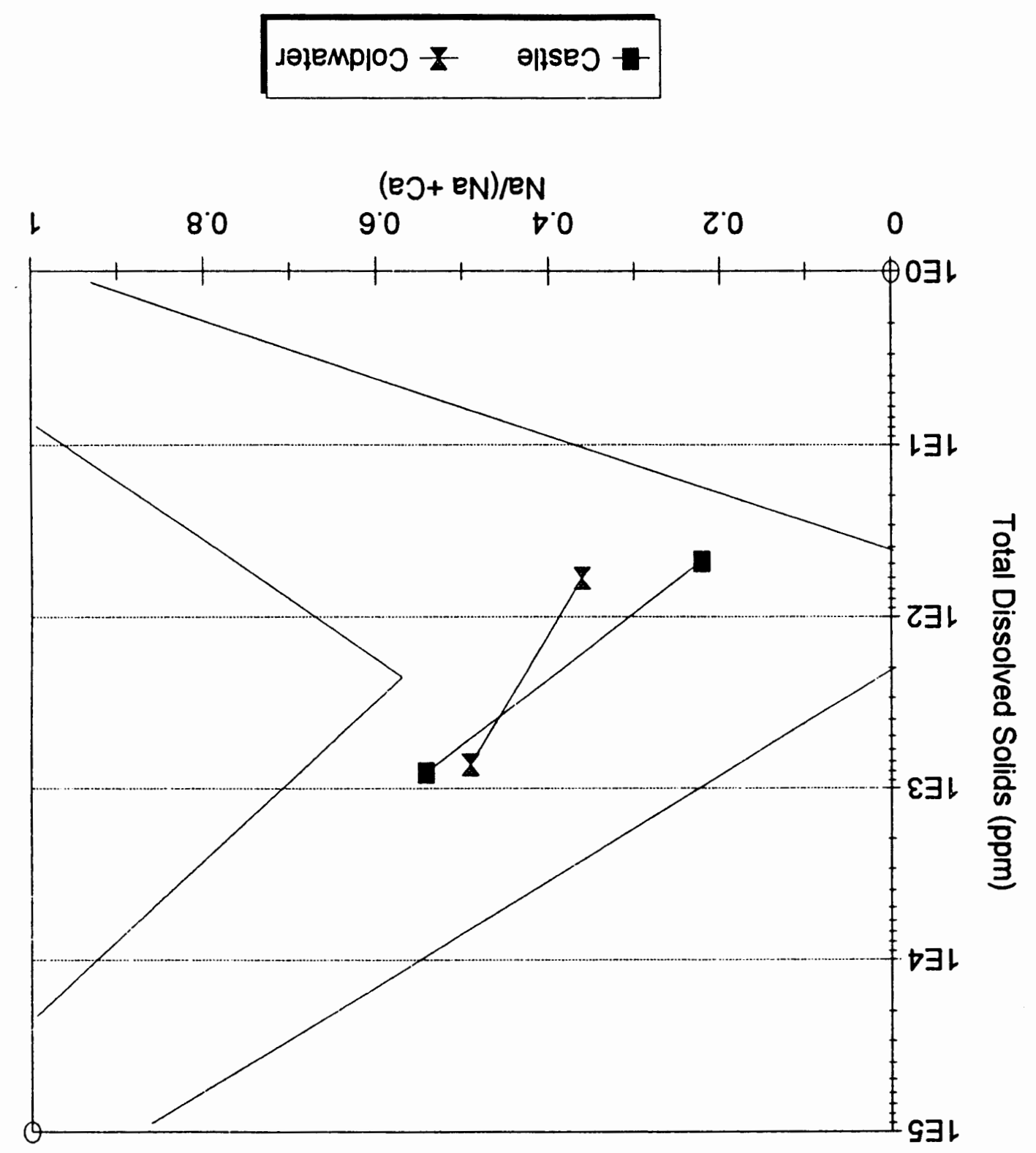

o ued - lәpow sqq!o '9f әjn6! 
$\mathrm{Na} /(\mathrm{Na}+\mathrm{Ca})$ ratio did not decline. This was a result of the high sodium levels introduced from the Spirit Lake water, which continued to influence the chemical composition of Coldwater Lake.

\section{ANALYSIS OF BIOLOGICAL DATA}

\section{Planktonic Communities}

Phytoplankton. In 1991, diatoms and small flagellates dominated the flora of all 12 lakes. Diatoms were the most common species in Fawn (Cyclotella comta), Hanaford (Cyclotella stelligera), Venus (Cyclotella stelligera), Coldwater (Cyclotella comta), June (Achnanthes lanceolata), McBride (Fragellaria crotonensis and synedra radians), and Merrill (Cyclotella comta) Lakes. Small flagellates were most abundant in Panhandle (Glenodinium sp.), Boot (Glenodinium sp.), Ryan (Dinobryon sertularia), st. Helens (Cryptomonas erosa), and Castle (Cryptomonas erosa) Lakes.

The 1993 lake flora varied considerably from 1991 as fewer lakes were dominated by diatoms; and cyanophytes and chlorophytes were dominant in several lakes. Small flagellates were most abundant in Panhandle (Glenodinium sp.), Boot (Glenodinium sp.), Hanaford (Cryptomonas erosa), and Ryan (Cryptomonas erosa) Lakes; while only June (Nitzschia palea and Diatoma hiemale) and Venus (Achnanthes minutissima) Lakes were dominated by diatoms. Cyanophytes were the most abundant species in Fawn (Microcystis 
aeruginosa), McBride (Microcystis aeruginosa), and Merrill (Aphanocapsa elachista) Lakes; and chlorophytes were most common in st. Helens (Ankistrodesmus falcatus), Castie (Quadrigula lacustris), and Coldwater (Planktoshpaeria gelatinosa) Lakes.

Zooplankton. The fauna reported for summer 1991 were typical zooplankton species observed in alpine lakes of the region (Petersen, 1993). In 1991 copepods were most abundant in Panhandle (Cyclops vernalis), st. Helens (Diaptomus kenai), Venus (Diaptomus kenai), June (Cyclops vernalis), and McBride (Diaptomus franciscanus) Lakes. Rotifers were most common in Boot (Keratella quadrata), Fawn (Kellicottia longispina), Hanaford (Keratella cochlearis), Castle (Kellicottia longispina), and Coldwater (Kellicottia longispina) Lakes; while cladocerans dominated Ryan (Daphnia rosea) and Merrill (Daphnia pulex) Lakes.

In 1993, rotifers were dominant in Panhandle (Kellicottia longispina), Boot (Keratella cochlearis), Fawn (Asplanchna sp.), Hanaford (Keratella cochlearis), st. Helens (Conchilus unicornis), Venus (Conchilus unicornis), Coldwater (Keratella cochlearis), June (Kellicottia longispina), McBride (Polyarthra sp.), and Merrill (Kellicottia bostoniensis) Lakes. Copepods were most abundant in Ryan (Diaptomus franciscanus) Lake; and cladocerans were most common in Castle (Daphnia pulex) Lake. 


\section{Cluster Analyses}

Biological data collected from all 12 lakes for 1991 and 1993 were analyzed to determine if ion chemistry influenced planktonic communities. Relationships between planktonic communities and ion concentrations were determined by comparison of lakes with similar planktonic communities and various functions of ion chemistry. similarities in planktonic community structure for the lakes were determined by performing cluster analyses on the biological data.

Cluster analyses were performed using the statistical software package systat (Systat, Inc.) and using the centroid clustering method. Pielou (1984) states the strength of centroid clustering is each cluster is represented by a specific point, the centroid, and the distance between clusters is the distance between their centroids. Other clustering methods offer no such geometrical realism.

Each of the four cluster analyses (Table VIII) resulted in one large cluster with four - one lake clusters. Lakes in the same cluster were considered "similar", while lakes in different clusters were considered "dissimilar" (Pielou, 1984). Clusters represent different biotic communities (Ludwig and Reynolds, 1988).

Most lakes were similar in planktonic community structure (cluster 1), with a few lakes having dissimilar 
structures. Lakes with plankton communities differing from cluster 1 were not dissimilar for both phyto- and zooplankton. The only lake to have dissimilar phyto- and zooplankton communities was Merrill Lake in 1993.

TABLE VIII

\section{PHYTOPLANKTON AND ZOOPLANKTON \\ CLUSTERS FOR 1991 AND 1993}

\begin{tabular}{|c|c|c|c|c|c|}
\hline clusters & 1 & 2 & 3 & 4 & 5 \\
\hline Phyto & $\begin{array}{l}\text { Panhandle } \\
\text { Fawn } \\
\text { Hanaford } \\
\text { StHelens } \\
\text { Castle } \\
\text { Coldwater } \\
\text { McBride } \\
\text { Merrill }\end{array}$ & Venus & Ryan & Boot & June \\
\hline Zoo & $\begin{array}{l}\text { Panhandle } \\
\text { Boot } \\
\text { Ryan } \\
\text { StHelens } \\
\text { Venus } \\
\text { Castle } \\
\text { Coldwater } \\
\text { June }\end{array}$ & Fawn & McBride & Merrill & Hanaford \\
\hline $\begin{array}{l}1993 \\
\text { Phyto }\end{array}$ & Boot & Merrill & MCBride & Panhandle & coldwater \\
\hline & $\begin{array}{l}\text { Fawn } \\
\text { Hanaford } \\
\text { Ryan } \\
\text { StHelens } \\
\text { Venus } \\
\text { Castle } \\
\text { June }\end{array}$ & & & & \\
\hline 200 & $\begin{array}{l}\text { Panhandle } \\
\text { Boot } \\
\text { Hanaford } \\
\text { Ryan } \\
\text { stHelens } \\
\text { Venus } \\
\text { Coldwater } \\
\text { McBride }\end{array}$ & Merrill & Fawn & June & Castle \\
\hline
\end{tabular}


Clusters versus ion data. Provasoli (1958) reviewed the literature on the influence of major elements on algal communities; including the effects of total dissolved solids, major cations and anions, monovalent to divalent cation ratio, and calcium to magnesium ratio. He found sufficient evidence exists that ion chemistry influences planktonic communities.

Lake clusters were compared with a variety of ion functions to determine if correlations existed between similar lake planktonic communities and ion concentrations. Although no literature information was obtained on the influence of ions on zooplankton, comparisons were made of ion functions with zooplankton clusters. Ion functions included; individual cations and anions, calcium to sodium ratio (Figure 17), calcium to magnesium ratio (Figure 18), monovalent/divalent cation ratio (Figure 19), sum of cations (Figure 20), alkalinity (Figure 21), conductivity (Figure 22), and total dissolved solids (Figure 23). Where applicable, comparisons for all ion functions were made with the biological data sets for 1991 and 1993.

The data for planktonic communities resulted in no clear correlations between lake biota clusters and ion functions. Diverse ion function values for cluster 1 hindered the interpretation of possible correlations in each trial. 
Figure 17. $\mathrm{Ca} / \mathrm{Na}$ Effect On

Zooplankton Communities

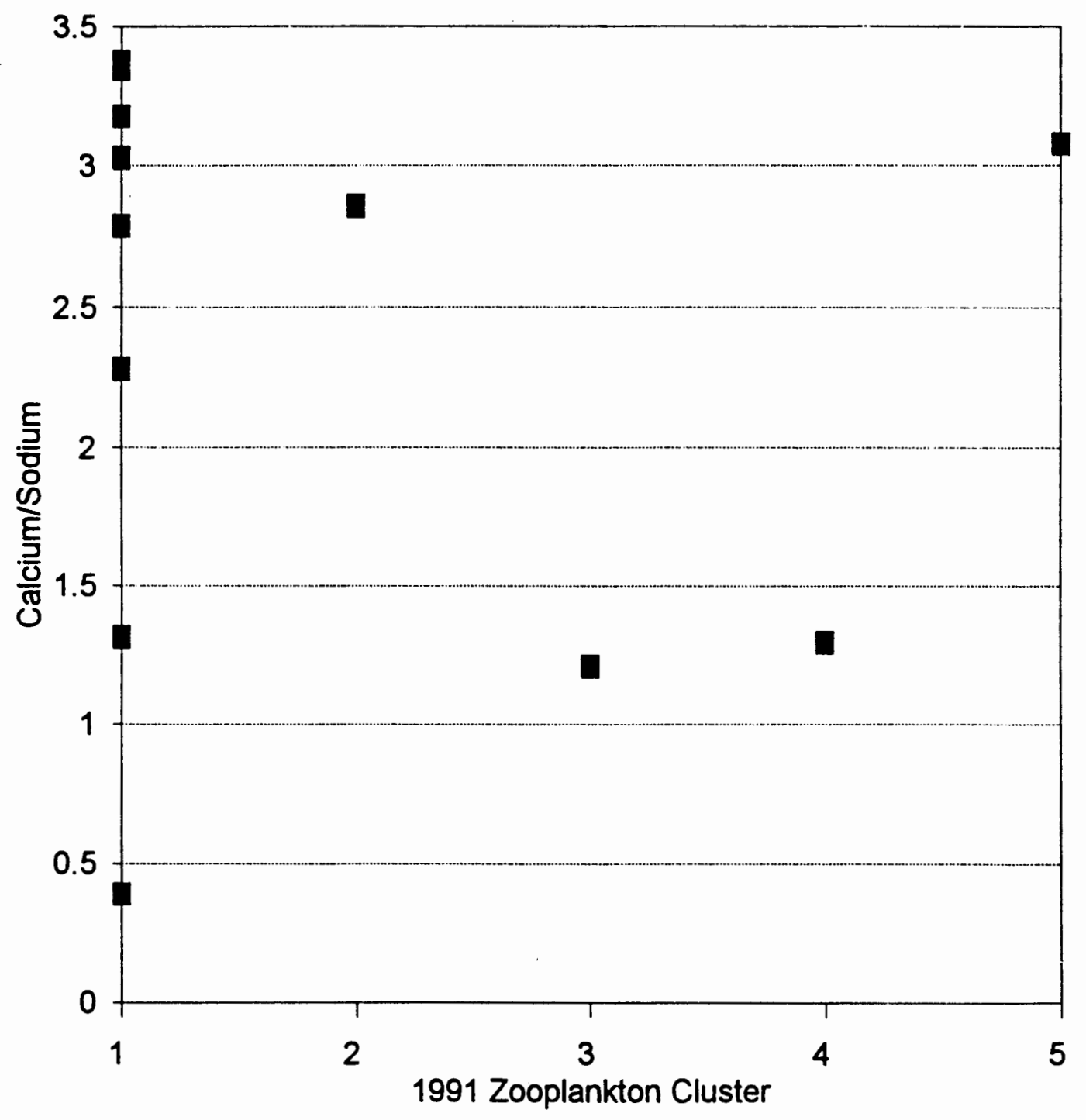


Figure 18. $\mathrm{Ca} / \mathrm{Mg}$ Effect On

Phytoplankton Communities




Figure 19. M:D Cation Ratio Effect On

Zooplankton Communities

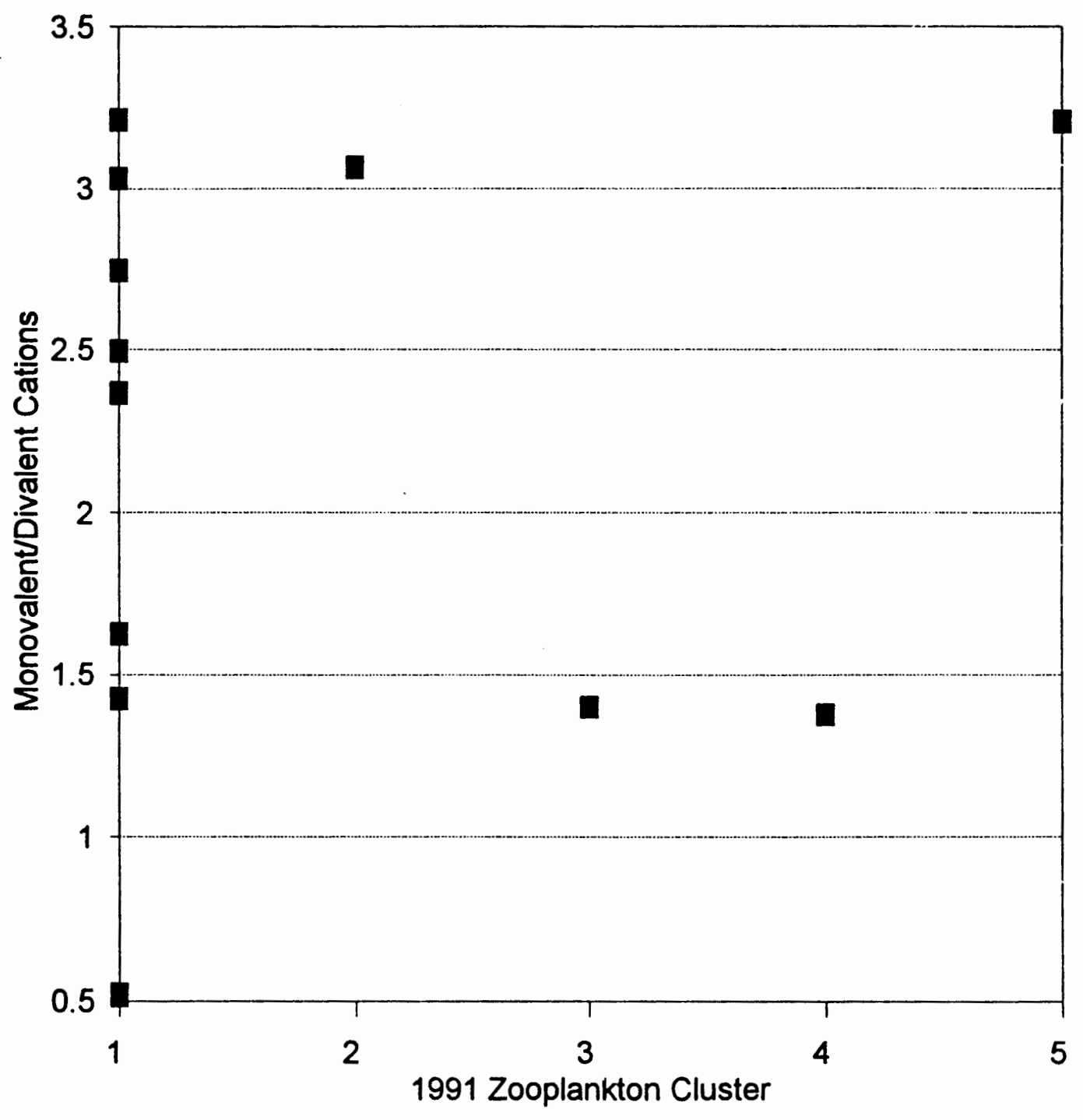


Figure 20. Cation Sum Effect On

Phytoplankton Communities

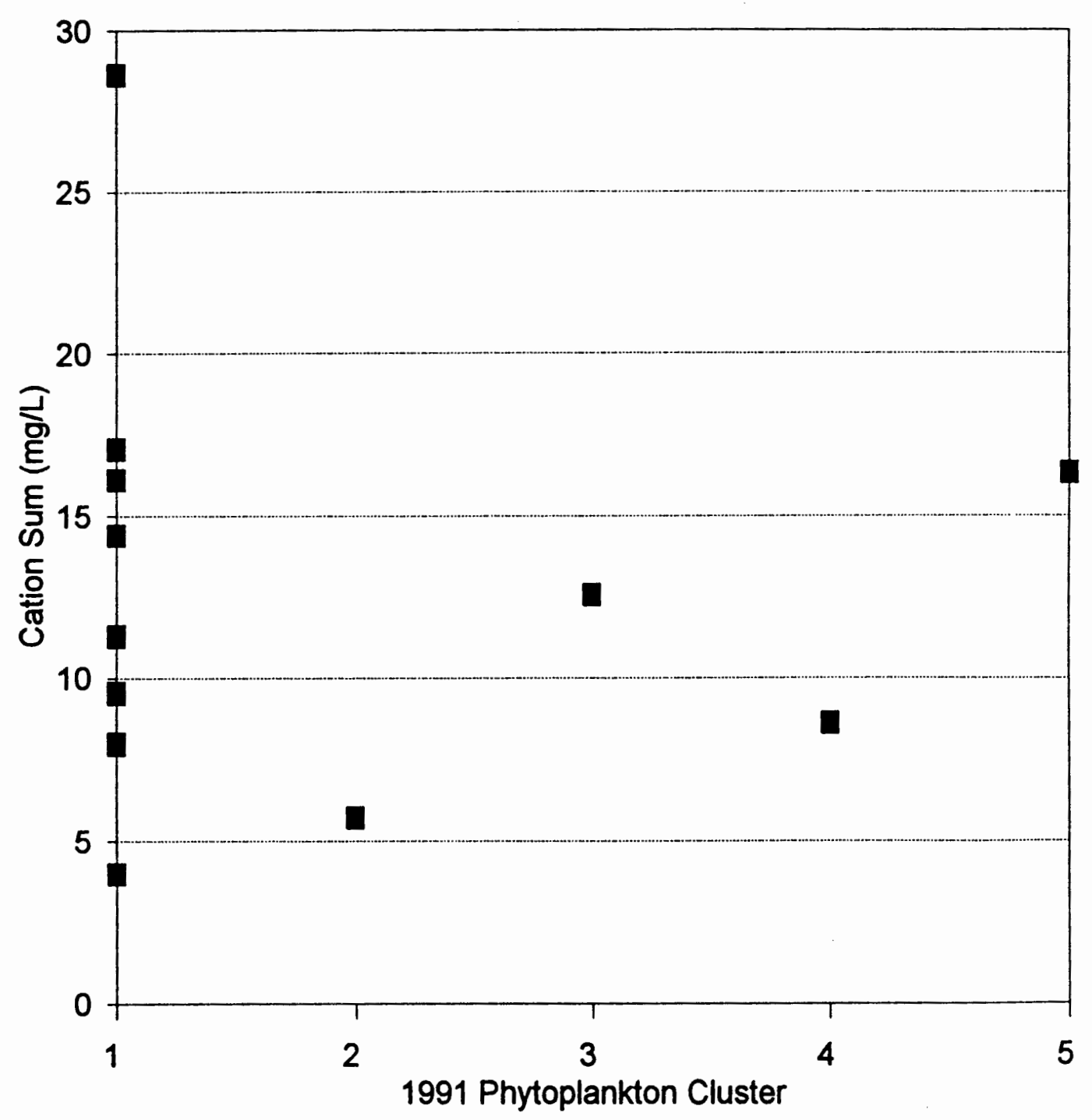


Figure 21. Alkalinity Effect On

Phytoplankton Communities




Figure 22. Conductivity Effect On

Zooplankton Communities

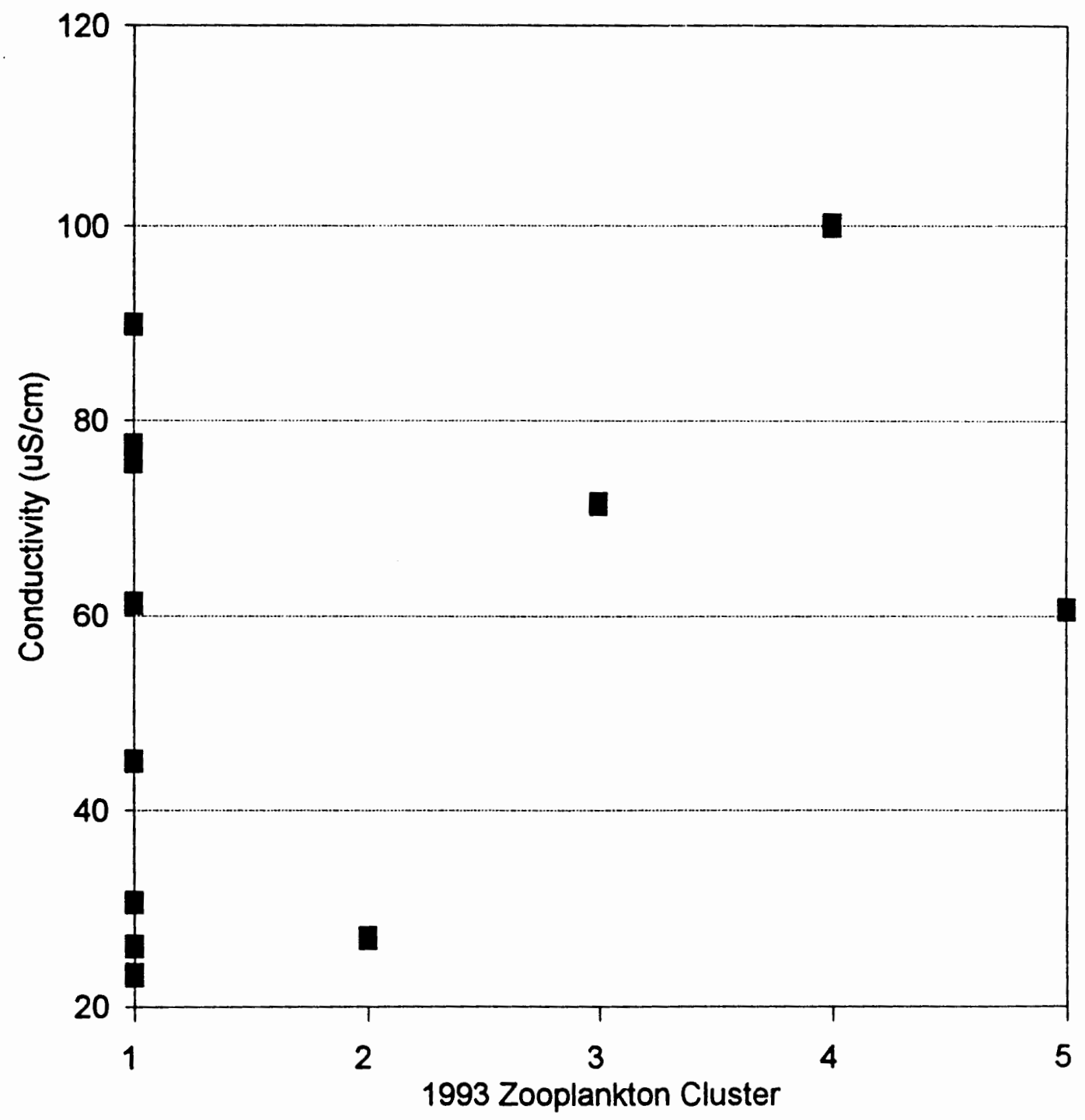


Figure 23. TDS Effect On

Phytoplankton Communities

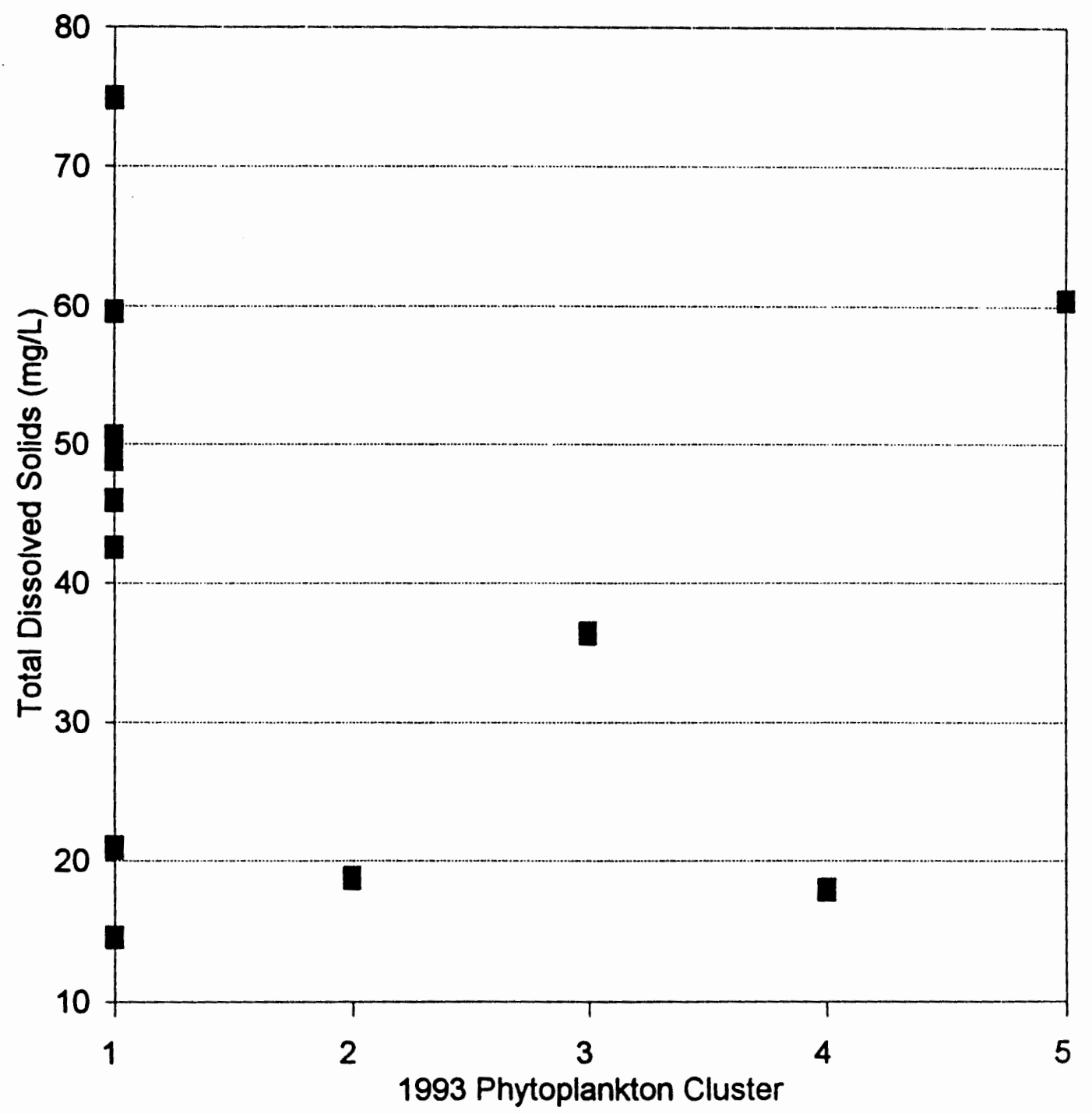


M:D Ratio And Diatom Percent Density

Diatom percent densities for each lake were observed as a function of the M:D ratio for 1991 and 1993 (Figures 24 and 25, respectively). Contrary to Wetzel's (1983) statement that the flora would be dominated by diatoms at $M: D$ ratios less than 1.5 ; most of the lakes had low percentages of diatoms at M:D ratios less than 1.5 . In 1991, some lakes with M:D ratios less than 1.5 had large diatom populations, although the majority of the lakes did not. None of the lakes, with $M: D$ ratios less than 1.5 , were dominated by diatoms in 1993.

The outlying lake, June Lake, had a high percentage of diatoms (approximately 99\%) with a M:D ratio greater than 1.5. The high percentage of diatoms in June Lake was not reflective of the lake flora. Diatoms likely were growing on rocks in the stream or waterfall and were being washed into the lake. 
Figure 24. M:D Cation Ratio Effect On 1991 Diatoms

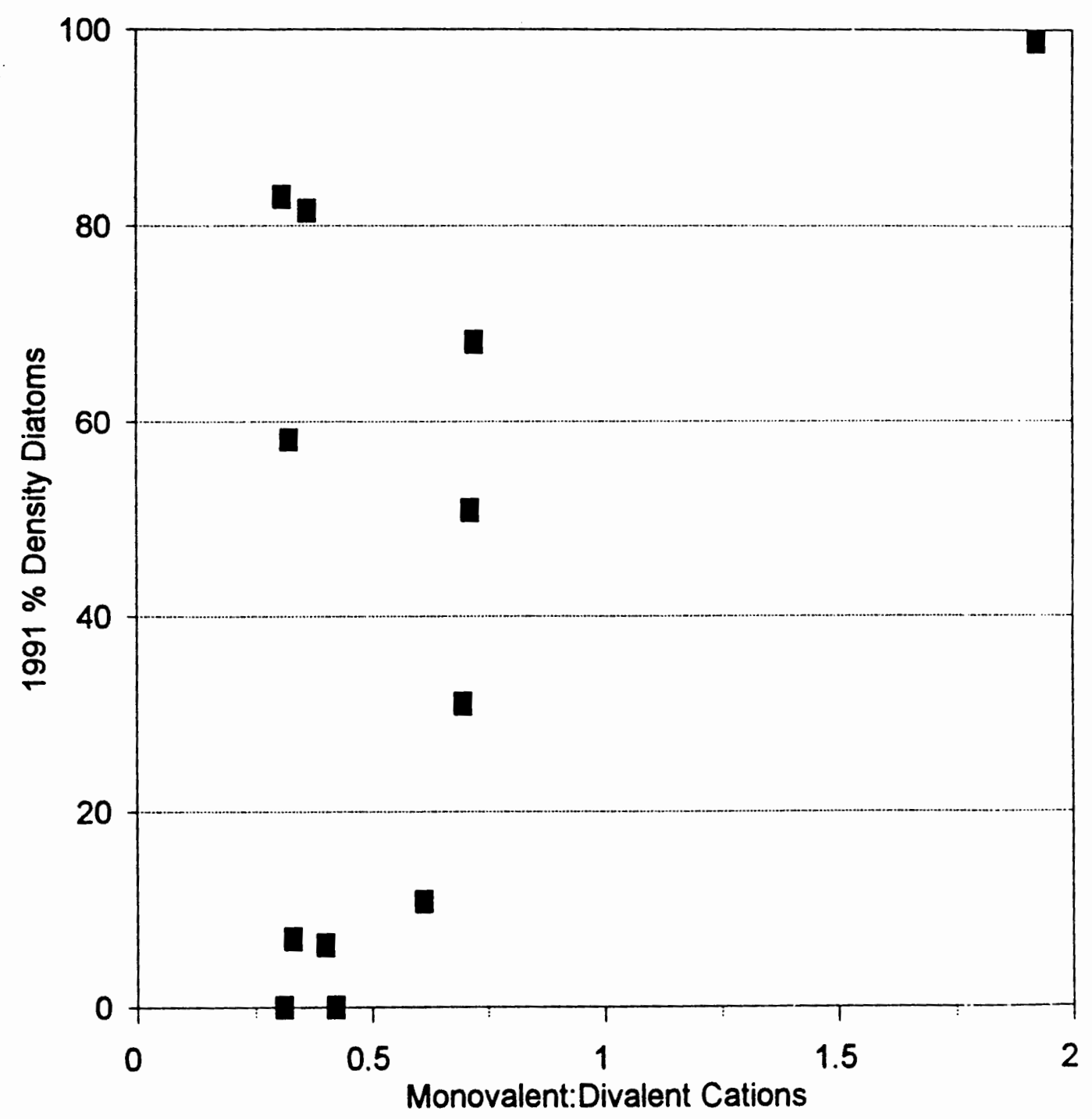


Figure 25. M:D Cation Ratio Effect On 1993 Diatoms






\section{CHAPTER $V$}

\section{DISCUSSION}

Dilution and ash weathering are the most important processes controlling the ion chemistry of lakes in the Mount st. Helens blast zone. Dilution played an important role in the ionic composition of the lakes, but dilution alone was not a sufficient explanation for the ion concentrations. It would be expected that all ions would have declined at similar relative rates if dilution were the sole reason for the chemical composition of the lakes.

Gibbs' models indicated total dissolved solids were decreasing as a result of dilution from high precipitation and runoff and the lakes plot in the rock weathering dominated region. Plots of theoretical dilution curves indicated a decline in ion concentrations as a result of dilution. Ion concentrations followed the exponential decline predicted by the dilution curve, although concentrations were higher than predicted by the curve. Increased concentrations were a result of the rapid weathering of ash in basins and on lake bottoms.

Rapid weathering of ash in lake watersheds and on lake bottoms continues to influence the ionic concentrations of the lakes. In general, sodium and potassium have declined 
at a much faster rate than calcium or magnesium. Slower relative declines in concentrations of calcium and magnesium were a result of more rapid rate of leaching of calcium and magnesium (Dethier, et al., 1981) from the ash.

Ash in the watersheds will continue to be a major contributor to the overall ion chemistry of the lakes until such time as the watersheds are stabilized by vegetation and a permanent soil layer. Ash on lake bottoms will be unavailable as sources of ionic constituents when it becomes buried within deep sediment layers.

Ion concentrations measured in the control lakes showed variation compared to regional mean values. Merrill Lake had similar concentrations to the regional means, while June and McBride Lakes were slightly higher. Ion concentrations observed in study lakes affected by the eruption were similar to those observed in June and McBride Lakes, but remained higher than Merrill, with few exceptions.

Variations in observed ion concentrations were a result of different ashfall patterns in lake basins (Table III) and differences in ion weathering rates. Although ion concentrations in affected lakes have declined to values observed in control lakes, most were at higher concentrations than the regional means.

Castle Lake had ion concentrations similar to those observed in control lakes, while concentrations in coldwater Lake were higher than control lakes. Compared to regional 
mean values both Castle and Coldwater Lakes were twice as concentrated.

Several functions of the ion chemistry were used to correlate planktonic community structure to lake ion chemistry. The data suggested ion chemistry was not influencing biological community structures as no patterns emerged. Analysis of diatom populations with respect to monovalent:divalent cation ratios did not produce the correlation predicted by Wetzel (1983). 
CHAPTER VI

REFERENCES

Baker, C. 1995. Phytoplankton Communities in The Lakes of Mount St. Helens. M.S. Thesis, Portland State University, Portland, Oregon. In Progress.

Baross, J.A.; Dahm, C.N. Ward, A.K.; Lilley, M.D. ; and Sedell, J.R. 1982. Initial microbiological response in lakes to the Mount St. Helens eruption. Nature. 296 (5852): 49-52.

Benoit, R.J. 1969. Geochemistry of Eutrophication. p614630. In Rohlich, G.A. (ed.). Eutrophication: Causes, Consequences, Correctives. National Academy of Science.

Berner, E.K. and Berner, R.A. 1987. The Global Water Cycle: Geochemistry and Environment. Prentice-Hall.

Collings, M.R. 1973. Data On Selected Lakes in Washington, Part 1. U.S. Geological Survey Open-File Report.

Dahm, C.N.; Baross, J.A.; Lilley, M.D.; Ward, A.K.; and Sedell, J.R. 1983. Initial effects of the Mount st. Helens eruption of nitrogen cycle and related processes in Ryan Lake. Applied and Environmental Microbiology. 45 (5): 1633-1645.

Dethier, D.P.; Pevear, D.R. ; and Frank, D. 1981. Alteration of New Volcanic Deposits: The 1980 Eruption of Mount St. Helens, Washington. U.S. Geological Survey Professional Paper 1250, 649-665.

Dion, N.P.; Bortleson, G.C.; McConnell, J.B.; and Innes, J.K. 1976. Data on Selected Lakes in Washington, Part 5. Washington Department of Ecology, Water-Supply Bulletin 42, Part 5 .

Dion, N.P. and Embry, S.S.; 1981, Effects of Mount st. Helens Eruption on Selected Lakes in Washington. U.S. Geological Survey Circular 850-G.

Drever, J.I. 1982. The Chemistry of Natural waters. Prentice-Hall. 
Edmondson, W.T. 1984. Volcanic ash in lakes. Northwest Environmental Journal. 1 (1): 139-150.

Eilers, J.M.; Brakke, D.F.; and Henriksen, A. 1992. The inapplicability of the Gibbs Model of world water chemistry for dilute lakes. Limnol. Oceanogr. 37 (6): 1335-1337.

Embry, S.S. and Dion, N.P. 1988. Effects of The 1980 Eruption of Mount St. Helens on The Limnological characteristics of Selected Lakes In Western Washington. U.S. Geological Survey, Water-Resources Investigations Report 87-4263.

Fruchter, J.S.; Robertson, D.E.; Evans, J.C.; Olsen, K.B.; Lepel, E.A.; Laul, J.C.; Abel, K.H.; Sanders, R.W.; Jackson, P.O.; Wogman, N.S.; Perkins, R.W.; Van TuY 1, H.H.;

Beauchamp, R.H.; Shade, J.W.; Daniel, J.L.; Erikson, R.L.; Sehmel, G.A.; Lee, R.N.; Robinson, A.V.; Moss, O.R. Briant, J.K.; and Cannon, W.C. 1980. Mount St. Helens ash from the 18 May 1980 eruption: Chemical, physical, mineralogical, and biological properties. Science. 209: 1116-1125.

Gibbs, R.J. 1970. Mechanisms controlling world water chemistry. Science. 170: 1088-1090.

Gibbs, R.J. 1992. A reply to the comment of Eilers et al. Limno1. Oceanogr. 37 (6): 1338-1339.

Guillard, R.L. 1962. Salt and Osmotic Balance. p529-540. In R.A. Lewin (ed.). Physiology and Biochemistry of Algae. Academic Press.

Hinkley, T.K. and Smith, K.S. 1987. Leachate Chemistry of Ash From The May 18, 1980, Eruption of Mount St. Helens. U.S. Geological Survey Professional Paper 1397.

Hoffer, J.M.; Hoffer, R.L.; and Shannon, W.M. 1982. Preliminary Analyses of The Composition And Texture May 18 , 1980, Mount St. Helens Tephra. p21-25. In S.A.C. Keller (ed.). Mount st. Helens: One Year Later. Eastern Washington University Press.

Hoffer, J.M. and Hoffer, R.L. 1986. Chemical Composition of The May 18, 1980 Mount St. Helens Tephra And The Underlying Soil: Changes From July 1980 To May 1981. p108111. In S.A.C. Keller (ed.). Mount St. Helens: Five Years Later. Eastern Washington University Press.

Hutchinson, G.E. 1975. A Treatise on Limnology, Volume 1: Geography, Physics, And Chemistry. Wiley and Sons. 
Ikramuddin, M.; Digby, S.J.M.; and Buehler, A.R. 1982 . Chemical composition of the Mount st. Helens Ash From The 18 May Eruption. p27-32. In S.A.C. Keller (ed.). Mount St. Helens: one Year Later. Eastern Washington University Press.

Kelly, V. J. 1992. Limnology of two new lakes, Mount st. Helens, Washington - 173 pp. M.S. Thesis, Portland state University, Portland oregon.

Kilham, P. 1990. Mechanisms controlling the chemical composition of lakes and rivers: Data from Africa. Limnol. oceanogr. 35 (1): 80-83.

Klock, G.0. 1982. Stabilizing ash-covered timberlands with erosion control seeding and fertilization. In Washington water Research Center, Proceedings from the conference, Mount St. Helens - Effects on water resources. Pullman, WA: Washington water Research Center Report 41: 164-190.

Landers, D.H.; Eilers, J.M.; Brakke, D.F.; Overton, w.S.; Kellar, , P.E.; Sliverstein, M.E.; Schonbrod, R.D.; Crowe, R.E.; Linthurst, R.A.; Omernik, J.M.; Teague, S.A.; and Meier, S.P. 1987. Western Lake Survey, Phase 1. U.S. Environmental Protection Agency, Washington, D.C.

Larson, D.W. and Glass, M.W. 1987. Spirit Lake, Mount st. Helens, Washington: Limnological and Bacteriological Investigations. U.S. Army Corps of Engineers.

Ludwig, J.A. and Reynolds, J.F. 1988. Statistical Ecology. John Wiley \& Sons.

McKnight, D.M.; Feder, G.L.; and Stiles, E.A. 1981. Effects on a blue-green alga of leachates of ash from the May 18 eruption. U.S. Geological Survey Report 1250.

Mcknight, D.M.; Klein, J.M.; and Wissmar, R.C. 1984 . Changes in the organic material in lakes in the blast zone of Mount st. Helens, Washington. U.S. Geological Survey Circular 850-L.

Nelson, P.O. 1991. Cascade Mountains. p531-563. In D.F. Charles (ed.). Acidic Precipitation and Aquatic Ecosystems. Springer-Verlag.

O'Kelly, J.C. 1968. Mineral nutrition of algae. A. Rev. P. Physiol. 19: 89-112.

Petersen, R.R. 1993. Recovery of lakes located in the blast zone of Mount st. Helens. Verh. Internat. Verein. Limnol. 25: 366-369. 
Provasoli, L. 1958. Nutrition and ecology of protozoa and algae. Ann. Rev. Microbiol. 12: 279-308.

Rushforth, S.R.; Squires, L.E.; and Cushing, C.E. 1986. Algal communities of springs and streams in the Mount st. Helens region, Washington, U.S.A. following the May 1980 eruption. J. Phycol. 22: 129-137.

Scharnberg, L. 1995. Zooplankton communities in The Lakes of Mount st. Helens. M.S. Thesis, Portland state University, Portland, Oregon. In Progress.

Skoog, D.A. 1985. Principles of Instrumental Analysis. Saunders College Publishing.

Smith, M.A. and White, M.J. 1985. Observations of lakes near Mount st. Helens: Phytoplankton. Archiv fuer Hydrobiologie. 104 (3): 345-362.

Staley, J.T.; Lehmicke, L.G.; Palmer, F.E.; Peet, R.W.; and Wissmar, R.C. 1982. Impact of Mount st. Helens eruption on bacteriology of lakes in the blast zone. Applied Environmental Microbiology. 43 (3): 664-670.

Taylor, H.E. and Lichte, F.E. 1980. Chemical composition of Mount st. Helens volcanic ash. Geophysical Research

Letters. 7 (11): 949-952.

U.S. Environmental Protection Agency. 1979. Methods For The Chemical Analysis of Water And Waste. EPA-600/4-79-020.

Welch, E. B. 1979. Lake Restoration BY Dilution. In U.S. Environmental Protection Agency. Lake Restoration. U.S. Government Printing office.

Wetzel, R.G. 1983. Limnology. Saunders.

Wetzel, R. G. and Likens, G. E. 1991. Limnological

Analyses. Springer-Verlag.

wissmar, R.C. 1982. Limnological Features of Lakes within The 18 May 1980 Mount st. Helens Blast Zone. p119-123. In S.A.C. Keller (ed.). Mount st. Helens: One Year Later. Eastern Washington University Press.

Wissmar, R.C.; Devol, A.H.; Nevissi, A.E.; and Sedell, J.R. 1982. Chemical changes of lakes within the Mount St. Helens blast zone. Science. 216 (4542): 175-178.

Wolcott, E.E. 1965. Lakes of Washington. State of Washington, Department of Conservation, Water supply Bulletin No. 14 . 


\section{APPENDIX A}

REFERENCES AND METHODOLOGIES UTILIZED FOR THE DETERMINATION OF THE PHYSICAL CHARACTERISTICS OF THE LAKES 
All values presented for lake distances from the crater were obtained from wissmar, et al. (1982). Lake surface area, volume, depth, and watershed area values for castle and Coldwater Lakes were presented by Kelly (1992). Values of those same characteristics for Fawn, st. Helens, and Venus Lakes were provided by Embry and Dion (1988) - Lake surface area and maximum depth for all other lakes were obtained from Wolcott (1965). All other values presented in Table I were determined by the following methods.

Lake volumes were calculated from bathymetric maps, when available. Bathymetric maps were available for Hanaford and Panhandle Lakes only. Volumes of the other lakes were calculated assuming the benthic profile was conical. While this method over-estimates the actual volume, it was the only method available which did not require a bathymetric map.

Mean depths were calculated as discussed by Wetzel (1983), where the mean depth was the volume divided by the surface area.

Lake watershed areas were determined through the use of areal photographs and topographic maps. Hanaford and Ryan Lakes' watersheds were determined from color areal photographs $($ scale $=1: 24000)$. Watershed areas for Merrill, McBride, June, Panhandle, and Boot Lakes were determined from United States Geological Survey 15 and 7.5 minute series topographical maps. 
Annual precipitation data reported in Table I was the average value from 1981 through 1993. Annual precipitation data was obtained by extrapolation from a series of precipitation gauges in the Mount st. Helens region.

Annual evapotranspiration values were determined by multiplying the evapotranspiration rate by the drainage area. The drainage area was the watershed area minus the lake surface area. The evapotranspiration rate for the Mount st. Helens area as reported by Embry and Dion (1988) was 20 inches $(0.508$ meter).

Evaporation from the lake surface was calculated by multiplying the evaporation rate by the lake surface area. The evaporation rate for lakes in the Mount st. Helens area from Embry and Dion (1988) was 24 inches ( 0.610 meter). Residence times were calculated using data obtained from previous calculations. Lake volume, annual precipitation, lake evaporation, and basin evapotranspiration were used to determine lake residence times. Lake volume was divided by the annual precipitation minus evaporation and evapotranspiration. 


\section{ANNUAL PRECIPITATION FOR STUDY LAKES}

(Values in inches)

Lake Hanaford

Fawn

St.Helens

Panhandle

Boot

Venus

Ryan

Castle

Coldwater

Merrill

McBride

June $\begin{array}{lllllllll}1981 & 1982 & 1983 & 1984 & 1985 & 1986 & 1987 & 1988 & 1989\end{array}$

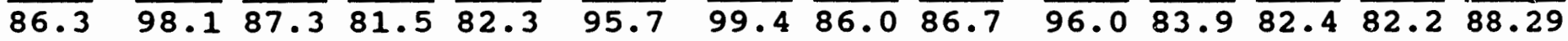
$\begin{array}{lllllllllllllll}83.8 & 94.9 & 85.3 & 78.3 & 79.7 & 92.8 & 96.1 & 83.7 & 83.8 & 93.7 & 81.3 & 79.6 & 79.4 & 85.57\end{array}$

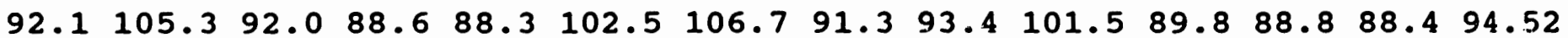
$\begin{array}{llllllllllllllll}92.5 & 105.9 & 92.4 & 89.2 & 88.7 & 102.9 & 107.3 & 91.7 & 93.9 & 101.9 & 90.2 & 89.2 & 88.9 & 94.98\end{array}$ $\begin{array}{lllllllllllllll}92.5 & 105.9 & 92.4 & 89.2 & 88.7 & 102.9 & 107.3 & 91.7 & 93.9 & 101.9 & 90.2 & 89.2 & 88.9 & 94.98\end{array}$ $\begin{array}{lllllllllllllll}92.5 & 105.9 & 92.4 & 89.2 & 88.7 & 102.9 & 107.3 & 91.7 & 93.9 & 101.9 & 90.2 & 89.2 & 88.9 & 94.98\end{array}$

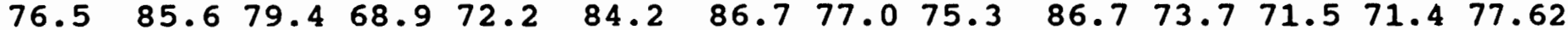


$\begin{array}{llllllllllllll}65.5 & 71.3 & 71.2 & 54.1 & 60.6 & 71.0 & 72.4 & 66.6 & 62.4 & 76.1 & 62.1 & 59.1 & 59.2 & 65.51\end{array}$ $\begin{array}{llllllllllllll}50.4 & 51.9 & 59.3 & 38.5 & 49.5 & 58.5 & 58.6 & 56.7 & 50.0 & 65.9 & 51.0 & 47.3 & 47.6 & 52.71\end{array}$ $\begin{array}{llllllllllllll}67.0 & 74.0 & 71.2 & 80.0 & 65.7 & 76.8 & 78.7 & 71.2 & 68.0 & 80.7 & 67.2 & 64.6 & 64.6 & 71.52\end{array}$ $\begin{array}{llllllllllllll}75.2 & 84.0 & 78.4 & 67.3 & 70.8 & 82.6 & 85.0 & 75.7 & 73.8 & 85.5 & 72.3 & 70.1 & 70.0 & 76.21\end{array}$ 


\section{APPENDIX B}

\section{CHEMICAL DATA FROM PAST LAKE STUDIES}




\section{PAST CHEMICAL DATA FOR PANHANDLE LAKE}

Ion Concentrations as $\mathrm{mg} / \mathrm{L}$ Alkalinity as $\mu \mathrm{eq} / \mathrm{L}$ Conductivity as $\mu \mathrm{S} / \mathrm{cm}$

\begin{tabular}{|c|c|c|c|c|c|c|c|c|c|}
\hline Year & {$\left[\mathrm{Ca}^{2+}\right]$} & {$\left[\mathrm{Mg}^{2+}\right]$} & {$\left[\mathrm{Na}^{ \pm}\right]$} & {$\left[\mathrm{K}^{ \pm}\right]$} & {$\left[\mathrm{Cl}^{-}=\right]$} & {$\left[\mathrm{SO}_{1}=\right]$} & {$\left[\mathrm{HCO}_{3}=\right]-$} & Alka & Cond \\
\hline $1980^{1}$ & 20.00 & 2.46 & 15.31 & 5.32 & 29.99 & 58.69 & ---- & 99.00 & --- \\
\hline $1991^{2}$ & 4.89 & 1.02 & 2.14 & 1.49 & ---- & ---- & -- & $-\cdots$ & \\
\hline $1993^{3}$ & 2.39 & 0.61 & 1.10 & 0.33 & 0.55 & 8.33 & 4.64 & 75.80 & 26 \\
\hline $1994^{3}$ & 2.40 & 0.54 & 1.07 & 0.34 & 0.48 & 6.98 & 3.37 & 55.01 & 22.0 \\
\hline
\end{tabular}




\section{PAST CHEMICAL DATA FOR BOOT LAKE}

Ion Concentrations as $\mathrm{mg} / \mathrm{L}$ Alkalinity as $\mu \mathrm{eq} / \mathrm{L}$ Conductivity as $\mu \mathrm{S} / \mathrm{cm}$

\begin{tabular}{|c|c|c|c|c|c|c|c|c|c|}
\hline Year & {$\left[\mathrm{Ca}^{2+}\right]$} & {$\left[\mathrm{Mg}^{2+}\right]$} & {$\left[\mathrm{Na}^{ \pm}\right]$} & {$\left[\mathrm{K}^{ \pm}\right]$} & {$[\mathrm{Cl}=]$} & {$\left[\mathrm{SO}_{4}{ }_{2}^{2-}\right]$} & {$\left[\mathrm{HCO}_{3}=\right]-$} & Alka & Cond \\
\hline $1980^{1}$ & 24.41 & 2.99 & 16.90 & 3.79 & 32.01 & 69.74 & --- & 195.00 & - \\
\hline $1991^{2}$ & 5.37 & 1.12 & 1.59 & 0.55 & $-\cdots$ & --- & $\cdots-$ & $\cdots-\cdots$ & \\
\hline $1993^{3}$ & 3.10 & 0.62 & 1.17 & 0.31 & 0.48 & 9.69 & 5.59 & 91.31 & 30.6 \\
\hline $1994^{3}$ & 3.05 & 0.63 & 1.16 & 0.25 & 0.42 & 8.73 & 2.65 & 43.32 & 28.2 \\
\hline
\end{tabular}




\section{PAST CHEMICAL DATA FOR FAWN LAKE}

Ion Concentrations as $\mathrm{mg} / \mathrm{L}$

Alkalinity as $\mu \mathrm{eq} / \mathrm{L}$

Conductivity as $\mu \mathrm{S} / \mathrm{cm}$

\begin{tabular}{|c|c|c|c|c|c|c|c|c|c|}
\hline Year & {$\left[\mathrm{Ca}^{2 \pm}\right]$} & {$\left[\mathrm{Mg}^{2+}\right]$} & {$\left[\mathrm{Na}^{ \pm}\right]$} & {$\left[\mathrm{K}^{ \pm}\right]$} & $[C]=]$ & {$\left[\mathrm{SO}_{1}{ }^{2-}\right]$} & {$\left[\mathrm{HCO}_{3}=\right]-$} & Alka & Cond \\
\hline $1980^{1}$ & 62.73 & 6.25 & 43.50 & 10.99 & 63.99 & 165.03 & $--=--$ & 6.82 & $666^{2}$ \\
\hline $1991^{3}$ & 8.66 & 2.19 & 3.03 & 0.51 & $-\cdots$ & ---- & - & $---\cdots$ & \\
\hline $1993^{4}$ & 10.23 & 2.10 & 2.78 & 0.35 & 1.55 & $21 \cdot 18$ & 21.45 & 350.44 & 71.5 \\
\hline & $\begin{array}{l}\text { rom Wis } \\
\text { rom Emb } \\
\text { rom Pet } \\
\text { Iurrent } \\
\text { Indicate }\end{array}$ & $\begin{array}{l}\text {, et } \\
\text { and } D \\
\text { sen, } 15 \\
\text { dy } \\
\text { missin }\end{array}$ & $\begin{array}{l}1.198 \\
\text { n, } 1985 \\
3 \\
\text { data. }\end{array}$ & & & & & & \\
\hline
\end{tabular}




\section{PAST CHEMICAL DATA FOR HANAFORD LAKE}

Ion Concentrations as $\mathrm{mg} / \mathrm{L}$ Alkalinity as $\mu \mathrm{eq} / \mathrm{L}$ Conductivity as $\mu \mathrm{S} / \mathrm{cm}$

\begin{tabular}{|c|c|c|c|c|c|c|c|c|c|}
\hline Year & {$\left[\mathrm{Ca}^{2+}\right]$} & {$\left[\mathrm{Mg}^{2+}\right]$} & {$\left[\mathrm{Na}^{ \pm}\right]$} & {$\left[\mathrm{K}^{ \pm}\right]$} & {$[\mathrm{Cl}=]$} & {$\left[\mathrm{sO}^{2} \underline{\underline{2}=]}\right.$} & $\mathrm{HCCO}_{3}=1-$ & Alka & Cond \\
\hline $1980^{1}$ & 57.80 & 5.59 & 58.00 & 24.01 & 86.00 & 195.00 & ---- & 461.00 & -- \\
\hline $1991^{2}$ & 9.98 & 2.31 & 3.24 & 0.59 & --- & --- & -- & ----- & \\
\hline $1993^{3}$ & 7.64 & 2.12 & 2.65 & 0.39 & 1.26 & 25.00 & 11.47 & 187.43 & 75.8 \\
\hline
\end{tabular}




\section{PAST CHEMICAL DATA FOR RYAN LAKE}

Ion Concentrations as $\mathrm{mg} / \mathrm{L}$

Alkalinity as $\mu e q / L$

Conductivity as $\mu \mathrm{S} / \mathrm{cm}$

\begin{tabular}{|c|c|c|c|c|c|c|c|c|c|}
\hline Year & {$\left[\mathrm{Ca}^{2+}\right]$} & {$\left[\mathrm{Mg}^{2+}\right]$} & {$\left[\mathrm{Na}^{ \pm}\right]$} & {$\left[\mathrm{K}^{ \pm}\right]$} & {$\left[\mathrm{Cl}^{\prime}=\right]$} & {$\left[\mathrm{SO}_{1}{ }^{2-}\right]$} & {$\left[\mathrm{HCO}_{3}=\right]-$} & Alka & Cond \\
\hline $1980^{1}$ & 27.82 & 2.84 & 17.61 & 5.79 & 27.01 & 79.83 & $--=--$ & 409.00 & --- \\
\hline $1991^{2}$ & 7.25 & 1.58 & 2.28 & 1.45 & $-\infty-\infty$ & --- & ---- & - & \\
\hline $1993^{3}$ & 6.39 & 1.61 & 2.10 & 1.13 & 0.75 & 13.97 & 16.58 & 270.88 & 61.3 \\
\hline
\end{tabular}


PAST CHEMICAL DATA FOR ST. HELENS LAKE

Ion Concentrations as $\mathrm{mg} / \mathrm{L}$

Alkalinity as $\mu \mathrm{eq} / \mathrm{L}$

Conductivity as $\mu \mathrm{S} / \mathrm{cm}$

\begin{tabular}{|c|c|c|c|c|c|c|c|c|c|}
\hline Year & {$\left[\mathrm{Ca}^{2+}\right]$} & {$\left[\mathrm{Mg}^{2+}\right]$} & {$\left[\mathrm{Na}^{ \pm}\right]$} & {$\left[K^{ \pm}\right]$} & {$\left[\mathrm{Cl}^{\prime}=\right]$} & {$\left[\mathrm{SO}_{4}{ }_{2-}\right]$} & {$\left[\mathrm{HCO}_{3}=\right]-$} & Alka & Cond \\
\hline $1980^{1}$ & 12.99 & 1.31 & 11.01 & 2.50 & 14.50 & 37.94 & $--=-$ & 110.00 & --- \\
\hline $1991^{2}$ & 10.46 & 1.73 & 3.75 & 1.13 & ---- & ---- & $\cdots$ & - & \\
\hline $1993^{3}$ & 8.15 & 1.40 & 3.04 & 0.83 & 3.51 & 22.73 & 9.20 & 150.35 & 77.5 \\
\hline $1994^{3}$ & 8.36 & 1.43 & 3.03 & 0.82 & 3.11 & 21.08 & 9.64 & 157.53 & 72.0 \\
\hline
\end{tabular}




\section{PAST CHEMICAL DATA FOR VENUS LAKE}

Ion Concentrations as $\mathrm{mg} / \mathrm{L}$

Alkalinity as $\mu \mathrm{eq} / \mathrm{L}$

Conductivity as $\mu \mathrm{S} / \mathrm{cm}$

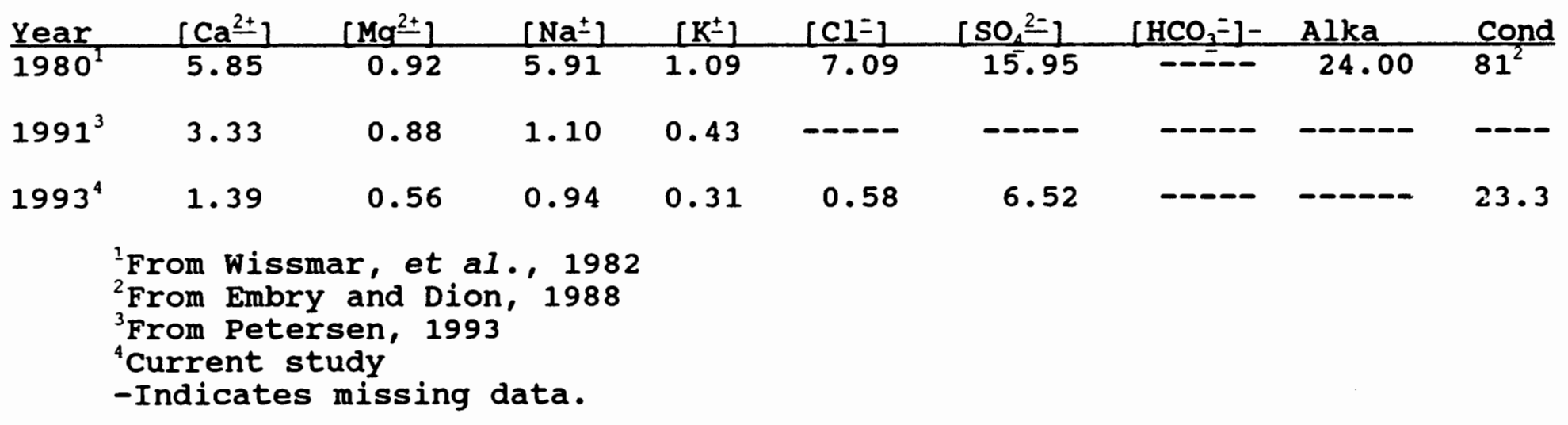




\section{PAST CHEMICAL DATA FOR CASTLE LAKE}

Ion Concentrations as $\mathrm{mg} / \mathrm{L}$

Alkalinity as $\mu \mathrm{eq} / \mathrm{L}$

Conductivity as $\mu \mathrm{S} / \mathrm{cm}$

\begin{tabular}{|c|c|c|c|c|c|c|c|c|c|}
\hline Year & {$\left[\mathrm{Ca}^{2+}\right]$} & {$\left[\mathrm{Mg}^{2+}\right]$} & {$\left[\mathrm{Na}^{ \pm}\right]$} & {$\left[\mathrm{K}^{ \pm}\right]$} & {$[\mathrm{Cl}=]$} & {$\left[\mathrm{SO}_{1}{ }^{2-}\right]$} & {$\left[\mathrm{HCO}_{3}=\right]-$} & Alka & \\
\hline $1980^{1}$ & 94.31 & 21.20 & 112.01 & 40.00 & 142.01 & 119.98 & $--\overline{---}$ & 4500.00 & - \\
\hline $1981^{2}$ & 45.29 & 10.21 & 15.17 & 3.13 & ---- & 25.94 & ---- & 1380.00 & \\
\hline $1982^{2}$ & 25.65 & 4.62 & 2.53 & 2.35 & ---- & ---- & -- & ------ & \\
\hline $1983^{2}$ & ---- & ---- & ---- & ---- & ---- & - & - - & 480.00 & \\
\hline $1984^{2}$ & 19.64 & 3.65 & 3.68 & 0.78 & ---- & --- & - & -- & \\
\hline $1989^{2}$ & 7.97 & 1.37 & 2.34 & 0.40 & 1.57 & 8.21 & ----- & -- & \\
\hline $1991^{3}$ & 7.54 & 1.07 & 2.25 & 0.43 & ---- & ---- & ----- & ----- & \\
\hline $1993^{4}$ & 7.66 & 1.27 & 2.18 & 0.29 & 0.94 & 5.97 & ----- & ----- & \\
\hline & $\begin{array}{l}\text { rom Wis } \\
\text { rom Kel } \\
\text { rrom Pet } \\
\text { Surrent } \\
\text { Indicate }\end{array}$ & $\begin{array}{l}\text { ar, et } \\
\text { ig92 } \\
\text { sen, } 1 \\
\text { udy } \\
\text { missin }\end{array}$ & $\begin{array}{l}\text { al, } 198 \\
93\end{array}$ & & & & & & \\
\hline
\end{tabular}


PAST CHEMICAL DATA FOR COLDWATER LAKE

Ion Concentrations as $\mathrm{mg} / \mathrm{L}$

Alkalinity as $\mu \mathrm{eq} / \mathrm{L}$

Conductivity as $\mu \mathrm{s} / \mathrm{cm}$

\begin{tabular}{|c|c|c|c|c|c|c|c|c|c|}
\hline Year & {$\left[\mathrm{Ca}^{2+}\right]$} & {$\left[\mathrm{Mg}^{2 \pm}\right]$} & {$\left[\mathrm{Na}^{ \pm}\right]$} & {$\left[\mathrm{K}^{ \pm}\right]$} & {$\left[\mathrm{Cl}^{-}=\right]$} & {$\left[\mathrm{SO}_{1}{ }^{2-}=\right]$} & {$\left[\mathrm{HCO}_{3}=\right]-$} & Alka & Cond \\
\hline $1980^{1}$ & 90.98 & 14.71 & 88.01 & 17.01 & 115.00 & 312.00 & $--=--$ & 1520.00 & $-\infty$ \\
\hline $1981^{2}$ & 61.72 & 13.61 & 24.37 & 3.91 & ----- & $---\infty$ & ---- & 1170.00 & --- \\
\hline $1982^{2}$ & 37.27 & 13.85 & ---- & 3.13 & ---- & ---- & ---- & $----\infty$ & --- \\
\hline $1984^{2}$ & 35.67 & 8.75 & 11.26 & 1.56 & ----- & ---- & - & 638.09 & --- \\
\hline $1989^{2}$ & 17.80 & 3.78 & 25.80 & 2.34 & 17.00 & 65.91 & 39.32 & --- & 171.95 \\
\hline $1991^{3}$ & 13.83 & 2.99 & 10.51 & 1.29 & ---- & ---- & ---- & ---- & -- \\
\hline $1993^{4}$ & 8.76 & 1.96 & 4.97 & 0.73 & 2.63 & 22.02 & 19.48 & 318.33 & 90.0 \\
\hline & $\begin{array}{l}\text { rom Wis } \\
\text { rom Kel } \\
\text { rom Pet } \\
\text { Surrent } \\
\text { Indicate }\end{array}$ & $\begin{array}{l}\text { ar, et } \\
1992 \\
\text { sen, } 19 \\
\text { ady } \\
\text { missin }\end{array}$ & $\begin{array}{l}a 1,, 198 \\
93\end{array}$ & & & & & & \\
\hline
\end{tabular}


PAST CHEMICAL DATA FOR JUNE LAKE

Ion Concentrations as $\mathrm{mg} / \mathrm{L}$

Alkalinity as $\mu \mathrm{eq} / \mathrm{L}$

Conductivity as $\mu \mathrm{S} / \mathrm{cm}$

\begin{tabular}{|c|c|c|c|c|c|c|c|c|c|}
\hline Year & {$\left[\mathrm{Ca}^{2+}\right]$} & {$\left[\mathrm{Mg}^{2+}\right]$} & {$\left[\mathrm{Na}^{ \pm}\right]$} & {$\left[\mathrm{K}^{ \pm}\right]$} & {$\left[\mathrm{Cl}_{1}=1\right.$} & {$\left[\mathrm{SO}_{2}=\right]$} & {$\left[\mathrm{HCO}_{3}=\right]-$} & Alka & Cond \\
\hline $1980^{1}$ & 4.05 & 1.53 & 8.81 & 1.56 & $\cdots$ & $-\ldots$ &  & 563.00 & -- \\
\hline $1991^{2}$ & 3.65 & 1.94 & 9.33 & 1.41 & $-\cdots$ & $\cdots$ & $-\cdots$ & $\cdots--$ & - \\
\hline $1993^{3}$ & 5.04 & 2.13 & 11.04 & 1.38 & 4.65 & 8.91 & 41.81 & 683.23 & 100.1 \\
\hline
\end{tabular}




\section{PAST CHEMICAL DATA FOR MCBRIDE LAKE}

Ion Concentrations as $\mathrm{mg} / \mathrm{L}$

Alkalinity as $\mu \mathrm{eq} / \mathrm{L}$

Conductivity as $\mu \mathrm{s} / \mathrm{cm}$

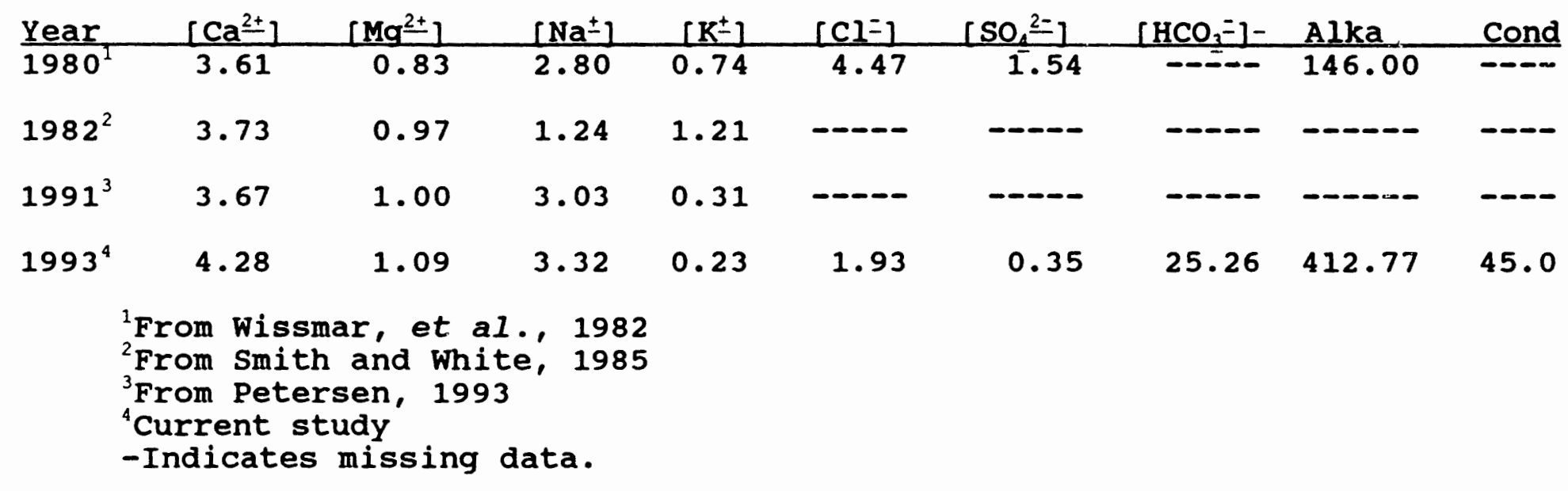




\section{PAST CHEMICAL DATA FOR MERRILI LAKE}

Ion Concentrations as $\mathrm{mg} / \mathrm{L}$ Alkalinity as $\mu \mathrm{eq} / \mathrm{L}$ Conductivity as $\mu \mathrm{S} / \mathrm{cm}$

\begin{tabular}{|c|c|c|c|c|c|c|c|c|c|}
\hline Year & {$\left[\mathrm{Ca}^{2+}\right]$} & {$\left[\mathrm{Mg}^{2 \pm}\right]$} & {$\left[\mathrm{Na}^{ \pm}\right]$} & {$\left[\mathrm{K}^{ \pm}\right]$} & {$[C I=]$} & {$\left[\mathrm{SO}_{1}, \underline{2-}\right]$} & {$\left[\mathrm{HCO}_{3}=\right]-$} & Alka & Cond \\
\hline $1980^{1}$ & 2.16 & 0.41 & 3.70 & 0.31 & 1.21 & 0.67 & $--=-$ & 126.00 & $-\infty$ \\
\hline $1991^{2}$ & 1.88 & 0.43 & 1.45 & 0.23 & ---- & ---- & ---- & $-\infty-\cdots$ & \\
\hline $1993^{3}$ & 2.43 & 0.49 & 1.55 & 0.11 & 0.77 & 0.57 & 12.89 & 210.63 & 27.0 \\
\hline
\end{tabular}




\section{APPENDIX C}

COMPARISON OF CATION CONCENTRATIONS OBTAINED

BY STANDARD CURVE AND KNOWN ADDITION 
CALCIUM
Summer 1993 Samples (Concentrations in $\mathrm{mg} / \mathrm{L}$ )

\begin{tabular}{llccc} 
Lake & Depth & St.Curve & Kn.Addtn & \&Diff. \\
Venus & Epi & 2.17 & 2.17 & 0.00 \\
& Meta & 2.35 & 2.40 & 2.08 \\
\multirow{2}{*}{ St.Helens } & Hypo & 2.70 & 2.69 & 0.37 \\
& Epi & & & \\
& Meta & 8.40 & 8.39 & 0.12 \\
\multirow{2}{*}{ Ryan } & Hypo & 8.92 & 9.34 & 4.50 \\
& Epi & 8.92 & 9.15 & 2.51 \\
& Meta & & & \\
& Hypo & 6.46 & 6.40 & 0.93 \\
& & 6.32 & 5.99 & 5.22 \\
& & 6.79 & 6.74 & 0.74
\end{tabular}

Panhandle

$\begin{array}{llll}\text { Epi } & 2.55 & 2.58 & 1.16 \\ \text { Meta } & 2.91 & 2.85 & 2.06 \\ \text { Hypo } & 3.24 & 3.07 & 5.25\end{array}$

McBride

Epi

4.03

4.03

0.00

June

Epi

5.14

5.13

0.19

Hanaford

Meta

Coldwater

Hypo

Epi

Meta

Merrill

Hypo

Boot

Epi

Meta

Hypo

Epi

Meta

Castle
Epi

7.70

7.82

8.22

8.79

8.67

8.72

2.54

2.56

2.57

3.10

3.61

4.00

Epi

Meta

Hypo
7.58

7.98

8.01
7.66

7.83

8.46

8.40

8.54

8.83

2.45

2.53

2. 57

0.52

0.13

2.84

4.44

1.50

1.25

3.54

1.17

0.00

3.03

3.54

3.86

2.26

1.94

3.50

7.73

8.12

7.61

1.94

1.72

4.99 
MAGNESIUM

Summer 1993 Samples (Concentrations in $\mathrm{mg} / \mathrm{L}$ )

\begin{tabular}{|c|c|c|c|c|}
\hline Lake & Depth & st. Curve & Kn.Addtn & gDiff. \\
\hline Venus & $\begin{array}{l}\text { Epi } \\
\text { Meta } \\
\text { Hypo }\end{array}$ & $\begin{array}{l}0.56 \\
0.61 \\
0.74\end{array}$ & $\begin{array}{l}0.54 \\
0.63 \\
0.74\end{array}$ & $\begin{array}{l}3.57 \\
3.17 \\
0.00\end{array}$ \\
\hline st.Helens & $\begin{array}{l}\text { Epi } \\
\text { Meta } \\
\text { Hypo }\end{array}$ & $\begin{array}{l}1.40 \\
1.51 \\
1.63\end{array}$ & $\begin{array}{l}1.39 \\
1.44 \\
1.62\end{array}$ & $\begin{array}{l}0.71 \\
4.64 \\
0.61\end{array}$ \\
\hline Ryan & $\begin{array}{l}\text { Epi } \\
\text { Meta } \\
\text { Hypo }\end{array}$ & $\begin{array}{l}1.61 \\
1.64 \\
1.61\end{array}$ & $\begin{array}{l}1.69 \\
1.74 \\
1.66\end{array}$ & $\begin{array}{l}4.73 \\
5.75 \\
3.01\end{array}$ \\
\hline & $\begin{array}{l}\text { Epi } \\
\text { Meta } \\
\text { Hypo }\end{array}$ & $\begin{array}{l}0.61 \\
0.68 \\
0.80\end{array}$ & $\begin{array}{l}0.63 \\
0.68 \\
0.80\end{array}$ & $\begin{array}{l}3.17 \\
0.00 \\
0.00\end{array}$ \\
\hline & Epi & 1.15 & 1.21 & 4.96 \\
\hline June & Epi & 2.13 & 2.20 & 3.18 \\
\hline Hanaford & $\begin{array}{l}\text { Epi } \\
\text { Meta } \\
\text { Hypo }\end{array}$ & $\begin{array}{l}2.12 \\
2.12 \\
2.19\end{array}$ & $\begin{array}{l}2.24 \\
2.23 \\
2.25\end{array}$ & $\begin{array}{l}5.36 \\
4.93 \\
2.67\end{array}$ \\
\hline Coldwazer & $\begin{array}{l}\text { Epi } \\
\text { Meta } \\
\text { Hypo }\end{array}$ & $\begin{array}{l}1.92 \\
1.96 \\
2.37\end{array}$ & $\begin{array}{l}2.00 \\
2.05 \\
2.50\end{array}$ & $\begin{array}{l}4.00 \\
4.39 \\
5.20\end{array}$ \\
\hline Merr & $\begin{array}{l}\text { Epi } \\
\text { Meta } \\
\text { Hypo }\end{array}$ & $\begin{array}{l}0.50 \\
0.52 \\
0.49\end{array}$ & $\begin{array}{l}0.53 \\
0.52 \\
0.50\end{array}$ & $\begin{array}{l}5.66 \\
0.00 \\
2.00\end{array}$ \\
\hline astie & $\begin{array}{l}\text { Epi } \\
\text { Meta } \\
\text { Hypo }\end{array}$ & $\begin{array}{l}1.27 \\
1.28 \\
1.39\end{array}$ & $\begin{array}{l}1.29 \\
1.31 \\
1.41\end{array}$ & $\begin{array}{l}1.55 \\
1.84 \\
1.42\end{array}$ \\
\hline
\end{tabular}




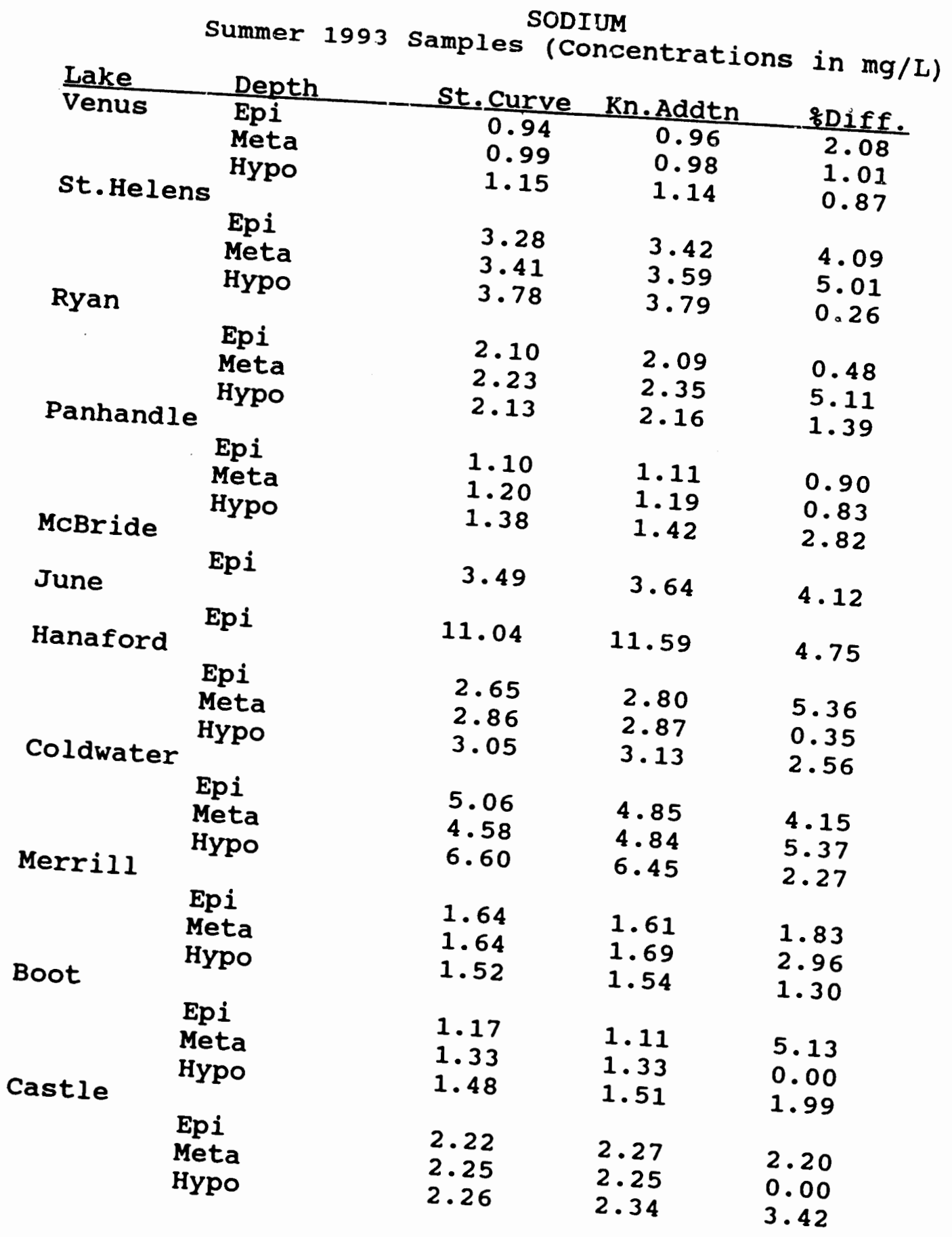


POTASSIUM

Summer 1993 Samples (Concentrations in $\mathrm{mg} / \mathrm{L}_{\text {. }}$ )

\begin{tabular}{|c|c|c|c|c|}
\hline \multirow{4}{*}{$\frac{\text { Lake }}{\text { Venus }}$} & Depth & st.Curve & Kn.Addtn & gDiff \\
\hline & Epi & 0.31 & 0.30 & 0.00 \\
\hline & Meta & 0.34 & 0.32 & 5.88 \\
\hline & Нуро & 0.41 & 0.42 & 2.38 \\
\hline \multirow{3}{*}{ St. Helens } & & & & \\
\hline & $\begin{array}{l}\text { Epi } \\
\text { Meta }\end{array}$ & $\begin{array}{l}0.88 \\
0.89\end{array}$ & $\begin{array}{l}0.88 \\
0.86\end{array}$ & $\begin{array}{l}0.00 \\
3.37\end{array}$ \\
\hline & Hypo & 1.03 & 1.01 & 1.94 \\
\hline \multirow{4}{*}{ Ryan } & & & & \\
\hline & Epi & 1.13 & 1.19 & 5.04 \\
\hline & Meta & 1.14 & 1.13 & 0.88 \\
\hline & нуро & 1.22 & 1.16 & 4.92 \\
\hline \multirow{4}{*}{ Panhandle } & & & & \\
\hline & Epi & 0.33 & 0.33 & 0.00 \\
\hline & Meta & 0.43 & 0.44 & 2.27 \\
\hline & нуро & 0.51 & 0.53 & 3.77 \\
\hline McBride & & $0 ? 2$ & 024 & 4.77 \\
\hline \multirow{2}{*}{ June } & Epl & 0.23 & 0.24 & 4.18 \\
\hline & Epi & 1.37 & 1.44 & 4.86 \\
\hline \multirow{3}{*}{ Hanaford } & Epi & 0.39 & 0.38 & 2.56 \\
\hline & Meta & 0.46 & 0.45 & 2.17 \\
\hline & нуро & 0.41 & 0.40 & 2.44 \\
\hline \multirow{4}{*}{ Coldwater } & & & & \\
\hline & Epi & 0.75 & 0.71 & 5.33 \\
\hline & Meta & 0.75 & 0.75 & 0.00 \\
\hline & нуро & 0.94 & 0.95 & 1.05 \\
\hline \multirow[t]{4}{*}{ Merrill } & & & & \\
\hline & Epi & 0.09 & 0.09 & 0.00 \\
\hline & Meta & 0.08 & 0.08 & 0.00 \\
\hline & нуро & 0.10 & 0.10 & 0.00 \\
\hline \multirow{3}{*}{ Boot } & & & & \\
\hline & $\begin{array}{l}\text { Epi } \\
\text { Meta }\end{array}$ & $\begin{array}{l}0.31 \\
0.36\end{array}$ & $\begin{array}{l}0.32 \\
0.38\end{array}$ & $\begin{array}{l}3.13 \\
5.26\end{array}$ \\
\hline & Hypo & 0.43 & 0.41 & 4.65 \\
\hline \multirow{3}{*}{ Castle } & & & & \\
\hline & Meta & $\begin{array}{l}0.32 \\
0.32\end{array}$ & $\begin{array}{l}0.28 \\
0.32\end{array}$ & $\begin{array}{l}0.61 \\
0.00\end{array}$ \\
\hline & Hypo & 0.37 & 0.36 & 2.70 \\
\hline
\end{tabular}


APPENDIX D

COMPARISON OF DETERMINED "UNKNOWN" CATION CONCENTRATIONS AND "TRUE" CONCENTRATIONS

FOR STANDARD CURVE AND KNOWN ADDITION 
STANDARD CURVE

(All Concentrations Are In $\mathrm{mg} / \mathrm{L}$ )

\begin{tabular}{|c|c|c|c|c|}
\hline \multirow{2}{*}{$\begin{array}{c}\text { Solution } \\
\text { Unknown Solution } \\
\text { Expt l Conc }\end{array}$} & $\mathrm{Ca}$ & $\mathrm{Mg}$ & $\mathrm{Na}$ & K \\
\hline & 98.78 & 108.85 & 108.77 & 51.69 \\
\hline True Conc & 100.00 & 100.00 & 100.00 & 50.00 \\
\hline \& Differ & $1.22 \%$ & $8.85 \%$ & $8.77 \%$ & $3.38 \%$ \\
\hline $\begin{array}{c}\text { Unknown solution } \\
\text { Exptl Conc }\end{array}$ & 10.13 & 10.51 & 10.77 & 10.20 \\
\hline True Conc & 10.00 & 10.00 & 10.00 & 10.00 \\
\hline \& Differ & $1.30 \%$ & $5.10 \%$ & $7.70 \%$ & $2.00 \%$ \\
\hline $\begin{array}{c}\text { Unknown Solution } \\
\text { Exptl Conc }\end{array}$ & 9.80 & 10.74 & 10.09 & 4.70 \\
\hline True Conc & 10.00 & 10.00 & 10.00 & 5.00 \\
\hline * Differ & $2.00 \%$ & $7.40 \%$ & $0.90 \%$ & $6.00 \%$ \\
\hline
\end{tabular}


KNOWN ADDITION

(A1l Concentrations Are In $\mathrm{mg} / \mathrm{L}$ )

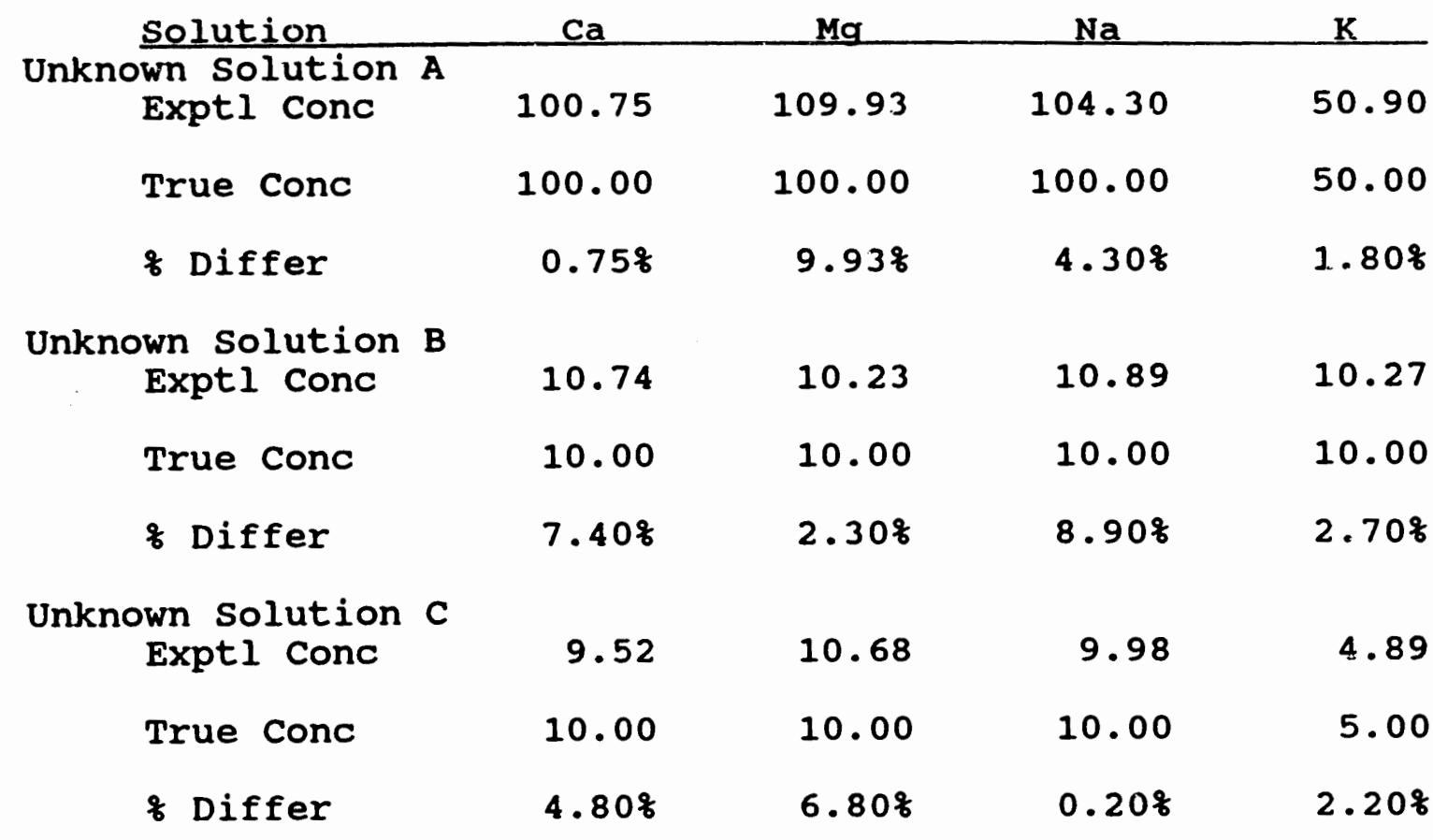


APPENDIX E

CURRENT CHEMICAL DATA COLLECTED FROM 1993 AND 1994 LAKE SAMPLES 


\section{CHEMICAL DATA FOR PANHANDLE LAKE \\ SAMPLE SEASON 1993}

\section{Ion Concentrations as $\mathrm{mg} / \mathrm{L}$ \\ Alkalinity as $\mu \mathrm{eq} / \mathrm{L}$ \\ Conductivity as $\mu \mathrm{S} / \mathrm{cm}$}

\begin{tabular}{|c|c|c|c|c|c|c|c|c|c|}
\hline Depth & {$\left[\mathrm{Ca}^{2+}\right]$} & {$\left[\mathrm{Mg}^{2 \pm}\right]$} & {$\left[\mathrm{Na}^{ \pm}\right]$} & {$\left[\mathrm{K}^{ \pm}\right]^{1}$} & $\begin{array}{l}\text { August } \\
{[\mathrm{Cl}=]}\end{array}$ & $\begin{array}{c}1993 \\
{\left[\mathrm{SO}_{2}=\right]}\end{array}$ & {$\left[\mathrm{HCO}_{3}=\right]^{1}=$} & Alka & Cond \\
\hline $1 \mathrm{~m}$ & 2.39 & 0.61 & 1.10 & 0.33 & 0.55 & 8.33 & $4 . \overline{6} 4$ & 75.80 & 26.2 \\
\hline 10 & 2.91 & 0.68 & 1.20 & 0.43 & 0.58 & 9.05 & 5.22 & 85.35 & 26.0 \\
\hline $\begin{array}{l}18 \\
{ }^{1} \mathrm{Calc}\end{array}$ & $\begin{array}{l}3.24 \\
\text { ed frc }\end{array}$ & $\begin{array}{l}0.80 \\
\text { alkal. }\end{array}$ & $\begin{array}{l}1.38 \\
y \text { data }\end{array}$ & $\begin{array}{l}0.51 \\
{[\mathrm{HCC}}\end{array}$ & $\begin{array}{l}0.68 \\
=A l k a\end{array}$ & $\begin{array}{c}9.13 \\
a * 0.0612\end{array}$ & 7.77 & 127.03 & 33.0 \\
\hline
\end{tabular}




\section{CHEMICAL DATA FOR BOOT LAKE \\ SAMPLE SEASON 1993 \\ Ion Concentrations as $\mathrm{mg} / \mathrm{L}$ Alkalinity as $\mu \mathrm{eq} / \mathrm{L}$ Conductivity as $\mu \mathrm{S} / \mathrm{cm}$}

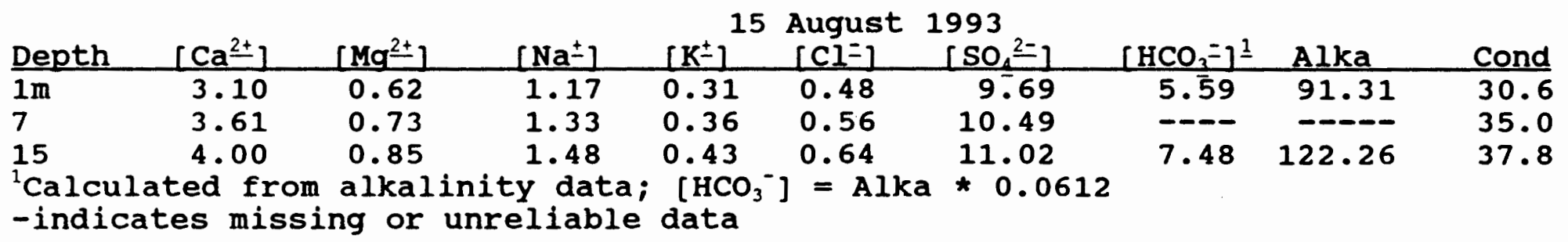


CHEMICAL DATA FOR FAWN LAKE

SAMPLE SEASON 1993

Ion Concentrations as $\mathrm{mg} / \mathrm{L}$ Alkalinity as $\mu \mathrm{eq} / \mathrm{L}$ Conductivity as $\mu \mathrm{S} / \mathrm{cm}$

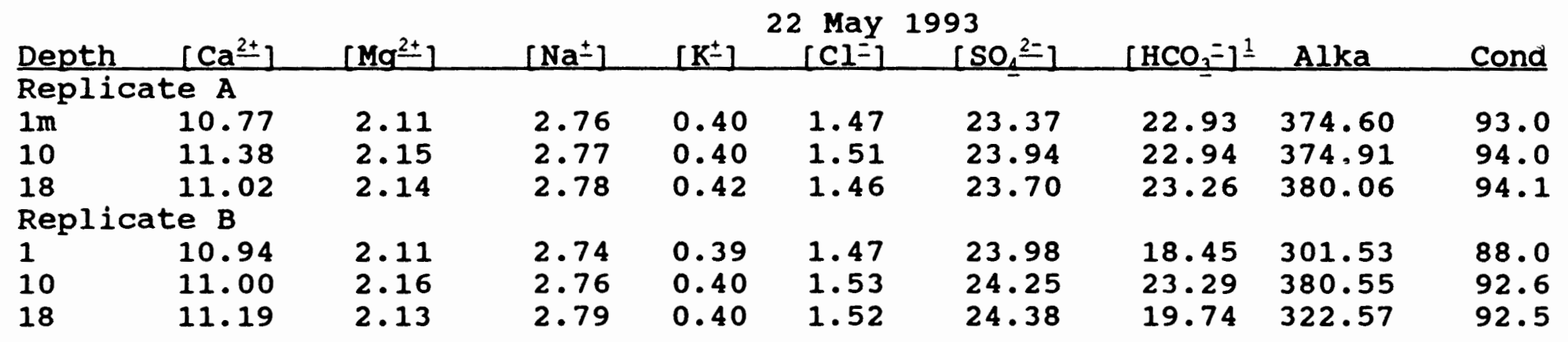

\begin{tabular}{|c|c|c|c|c|c|c|c|c|c|}
\hline Depth & {$\left[\mathrm{Ca}^{2+}\right]$} & {$\left[\mathrm{Mg}^{2+}\right]$} & {$\left[\mathrm{Na}^{ \pm}\right]$} & {$\left[\mathrm{K}^{ \pm}\right]$} & $\begin{array}{c}\text { August } \\
{[\mathrm{Cl}=]}\end{array}$ & $\begin{array}{l}1993 \\
{\left[50_{1}=\right]}\end{array}$ & {$\left[\mathrm{HCO}_{3}=\right]^{1}$} & Alka & Cond \\
\hline $1 \mathrm{~m}$ & 10.23 & 2.10 & 2.78 & 0.35 & 1.55 & 21.18 & 21.45 & 350.44 & 71.5 \\
\hline 10 & 11.29 & 2.21 & 2.81 & 0.42 & 1.56 & 23.57 & 25.20 & 411.83 & $-\infty$ \\
\hline 18 & 11.43 & --- & 2.91 & 0.46 & 1.66 & 23.78 & 25.50 & 416.69 & 82.2 \\
\hline
\end{tabular}

${ }^{1}$ Calculated from alkalinity data; $\left[\mathrm{HCO}_{3}{ }^{-}\right]=A l k a * 0.0612$

- indicates missing or unreliable data 
CHEMICAL DATA FOR FAWN LAKE

SAMPLE SEASON 1993

(Continued)

Ion Concentrations as $\mathrm{mg} / \mathrm{L}$

Alkalinity as $\mu \mathrm{eq} / \mathrm{L}$

Conductivity as $\mu \mathrm{S} / \mathrm{cm}$

\begin{tabular}{|c|c|c|c|c|c|c|c|c|c|}
\hline & & & & 2 & OC & 1993 & & & \\
\hline Depth & {$\left[\mathrm{Ca}^{2 \pm}\right]$} & {$\left[\mathrm{Mg}^{2 \pm}\right]$} & {$\left[\mathrm{Na}^{ \pm}\right]$} & {$\left[\mathrm{K}^{ \pm}\right]$} & {$[\mathrm{Cl}=]$} & {$\left[\mathrm{SO}_{-}^{2-}\right]$} & {$\left[\mathrm{HCO}_{3}=\right]^{-1}$} & Alka & Cond \\
\hline & 92 & 2.17 & 2.56 & 0.35 & 1.46 & 20.84 & $22 . \overline{6} 6$ & 370.22 & 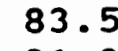 \\
\hline 10 & 11.22 & 2.18 & 2.84 & 0.44 & 1.58 & 22.46 & 23.71 & 387.45 & 91.9 \\
\hline 18 & 12.20 & 2.22 & 2.93 & 0.48 & 1.63 & 23.11 & 26.52 & 433.40 & 96.0 \\
\hline
\end{tabular}

${ }^{1}$ Calculated from alkalinity data; $\left[\mathrm{HCO}_{3}{ }^{-}\right]=$Alka $* 0.0612$ 


\section{CHEMICAL DATA FOR HANAFORD LAKE SAMPLE SEASON 1993}

\section{Ion Concentrations as $\mathrm{mg} / \mathrm{L}$ Alkalinity as $\mu$ eq/L Conductivity as $\mu \mathrm{S} / \mathrm{cm}$}

\begin{tabular}{|c|c|c|c|c|c|c|c|c|c|}
\hline Depth & {$\left[\mathrm{Ca}^{2 \pm}\right]$} & {$\left[\mathrm{Mg}^{2 \pm}\right]$} & {$\left[\mathrm{Na}^{ \pm}\right]$} & {$\left[\mathrm{K}^{ \pm}\right]$} & $\begin{array}{l}\mathrm{May} \\
[\mathrm{C}]=]\end{array}$ & $\begin{array}{l}1993 \\
{\left[\mathrm{SO}_{4}=\right]}\end{array}$ & {$\left[\mathrm{HCO}_{3}=\right]^{\underline{1}}$} & Alka & Cond \\
\hline \multicolumn{10}{|c|}{ Replicate A } \\
\hline $1 \mathrm{~m}$ & 7.76 & 2.16 & 2.69 & 0.40 & 1.23 & 26.09 & 10.43 & 170.46 & 76.3 \\
\hline 8 & 7.89 & 2.15 & 2.73 & 0.39 & 1.29 & 26.39 & $--\infty$ & $-\infty-\infty$ & 78.0 \\
\hline & 7.97 & 2.17 & 2.72 & 0.39 & 1.29 & 26.48 & --- & $-\cdots-$ & 77. \\
\hline \multicolumn{10}{|c|}{ Replicate B } \\
\hline $1 \mathrm{~m}$ & 7.82 & 2.13 & 2.72 & 0.39 & 1.23 & 25.97 & 11.26 & 184.06 & 78 . \\
\hline 8 & 7.91 & 2.16 & 2.74 & 0.39 & 1.28 & 26.39 & 9.75 & 159.27 & 00 \\
\hline 14 & 7.92 & 2.15 & 2.75 & 0.39 & 1.34 & 26.91 & 10.34 & 168.99 & \\
\hline
\end{tabular}

\begin{tabular}{|c|c|c|c|c|c|c|c|c|c|}
\hline Depth & {$\left[\mathrm{Ca}^{2 \pm}\right]$} & {$\left[\mathrm{Mg}^{24}\right]$} & {$\left[\mathrm{Na}^{ \pm}\right]$} & {$\left[K^{ \pm}\right]$} & $\begin{array}{c}\text { August } \\
{[C l=]}\end{array}$ & $\begin{array}{r}1993 \\
{\left[\mathrm{SO}_{1}{ }_{2}^{2-}\right]}\end{array}$ & {$\left[\mathrm{HCO}_{3}=\right]^{1}$} & Alka & Cond \\
\hline$\overline{1 m}$ & 7.64 & 2.12 & 2.65 & 0.39 & 1.26 & 25.00 & $11 . \overline{4} 7$ & 187.43 & 75.8 \\
\hline 10 & 7.82 & 2.12 & 2.72 & 0.39 & 1.31 & 25.63 & $\overline{1}$ & 100 & 76.2 \\
\hline 14 & 8.22 & 2.19 & 2.87 & 0.41 & 1.49 & 26.60 & 12.03 & 196.58 & 81.2 \\
\hline
\end{tabular}

${ }^{1}$ Calculated from alkalinity data; $\left[\mathrm{HCO}_{3}{ }^{-}\right]=\mathrm{Alka} * 0.0612$

- indicates missing or unreliable data 


\section{CHEMICAL DATA FOR HANAFORD LAKE}

SAMPLE SEASON 1993

(Continued)

\section{Ion Concentrations as $\mathrm{mg} / \mathrm{L}$ Alkalinity as $\mu \mathrm{eq} / \mathrm{L}$ Conductivity as $\mu \mathrm{s} / \mathrm{cm}$}

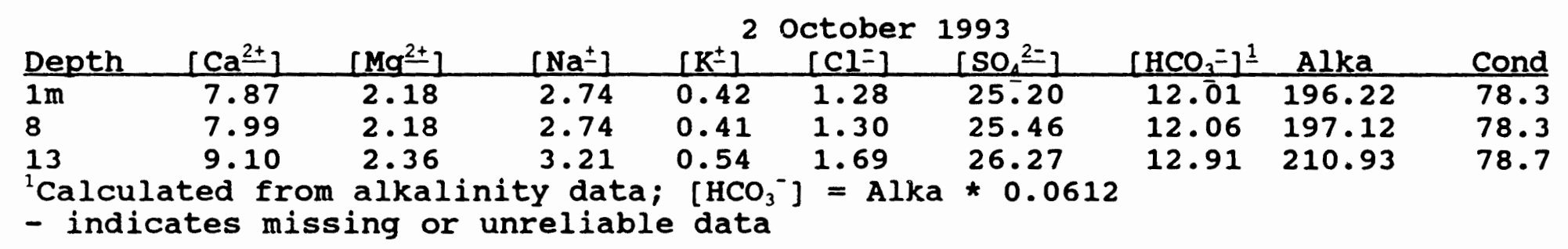




\section{CHEMICAL DATA FOR RYAN LAKE \\ SAMPLE SEASON 1993}

Ion Concentrations as $\mathrm{mg} / \mathrm{L}$

Alkalinity as $\mu \mathrm{eq} / \mathrm{L}$

Conductivity as $\mu \mathrm{S} / \mathrm{cm}$

\begin{tabular}{|c|c|c|c|c|c|c|c|c|c|}
\hline \multirow[b]{2}{*}{ Depth } & \multicolumn{9}{|c|}{993} \\
\hline & {$\left[\mathrm{Ca}^{2+}\right]$} & {$\left[\mathrm{Mg}^{2+}\right]$} & {$\left[\mathrm{Na}^{ \pm}\right]$} & {$\left[K^{ \pm}\right]$} & {$[\mathrm{Cl}=]$} & {$\left[\mathrm{SO}_{2}=1\right.$} & {$\left[\mathrm{HCO}_{3}=\right]^{1}$} & Alka & Cond \\
\hline $1 \mathrm{~m}$ & 6.21 & 1.57 & 2.09 & 1.20 & 0.82 & 13.76 & $14 . \overline{8} 3$ & 242.34 & 7 \\
\hline & & 1. & 2.06 & 1.22 & 0.84 & 15.23 & $-2--1$ & $-10-1$ & 58.4 \\
\hline & 6.64 & 1.68 & 2.15 & 1.23 & 0.84 & 15.59 & 15.38 & 251.29 & 64.0 \\
\hline
\end{tabular}

\begin{tabular}{|c|c|c|c|c|c|c|c|c|c|}
\hline Depth & {$\left[\mathrm{Ca}^{2+}\right]$} & {$\left[\mathrm{Mq}^{2+}\right]$} & {$\left[\mathrm{Na}^{ \pm}\right]$} & {$\left[\mathrm{K}^{ \pm}\right]$} & $\begin{array}{l}\text { Augus } \\
{[C l=1}\end{array}$ & 1993 & {$\left[\mathrm{HCO}_{2}=1 \underline{1}\right.$} & Alka & Cond \\
\hline $1 \mathrm{~m}$ & 6.39 & 1.61 & 2.10 & 1.13 & 0.75 & 13.97 & $16 . \overline{58}$ & 270.88 & 61. \\
\hline 4 & 6.51 & 1.64 & 2.11 & 1.14 & 0.76 & 14.11 & 16.05 & 262.23 & 59. \\
\hline 6 & 6.79 & 1.61 & 2.13 & 1.22 & 0.76 & 12.91 & -..- & - & 60 \\
\hline
\end{tabular}

9 October 1993

\begin{tabular}{lccccccccc} 
Depth & {$\left[\mathrm{Ca}^{2+}\right]$} & {$\left[\mathrm{Mg}^{2+}\right]$} & {$\left[\mathrm{Na}^{ \pm}\right]$} & {$\left[\mathrm{K}^{ \pm}\right]$} & {$\left[\mathrm{Cl}^{2+}\right]$} & {$\left[\mathrm{SO}_{2}{ }^{2-}\right]$} & $\left.\left[\mathrm{HCO}_{3}\right]\right]^{1}$ & $\mathrm{~A}] \mathrm{ka}$ & Cond \\
\hline $1 \mathrm{~m}$ & 6.45 & 1.74 & 2.17 & 1.18 & 0.74 & 13.20 & 18.98 & 310.07 & 61.5 \\
4 & 6.54 & 1.64 & 1.93 & 1.17 & 0.75 & 13.70 & 19.06 & 311.46 & 61.2 \\
6 & 6.51 & 1.71 & 2.16 & 1.17 & 0.75 & 13.57 & 19.02 & 310.84 & 62.8
\end{tabular}

${ }^{1} \mathrm{Calculated}$ from alkalinity data; $\left[\mathrm{HCO}_{3}{ }^{-}\right]=\mathrm{Alka} * 0.0612$

-indicates missing or unreliable data 


\section{CHEMICAI DATA FOR ST. HELENS LAKE \\ SAMPLE SEASON 1993}

Ion Concentrations as $\mathrm{mg} / \mathrm{L}$

Alkalinity as $\mu \mathrm{eq} / \mathrm{L}$

Conductivity as $\mu S / L$

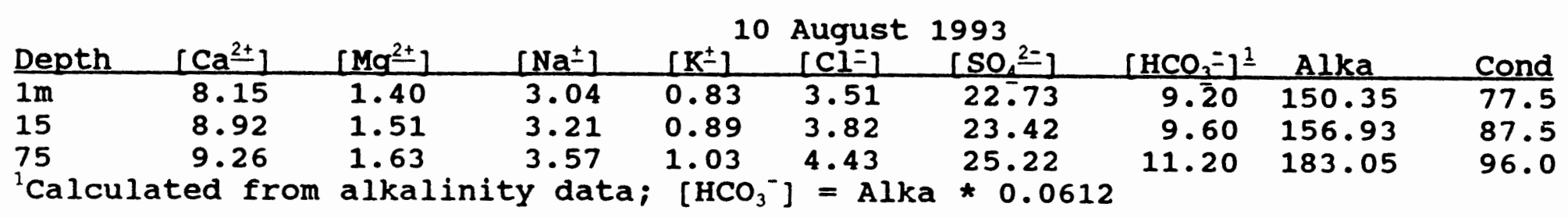




\section{CHEMICAL DATA FOR VENUS LAKE \\ SAMPLE SEASON 1993}

Ion Concentrations as $\mathrm{mg} / \mathrm{L}$ Alkalinity as $\mu \mathrm{eq} / \mathrm{L}$ Conductivity as $\mu \mathrm{S} / \mathrm{cm}$




CHEMICAL DATA FOR CASTLE LAKE

SAMPLE SEASON 1993

Ion Concentrations as $\mathrm{mg} / \mathrm{L}$
Alkalinity as $\mu \mathrm{eq} / \mathrm{L}$
Conductivity as $\mu \mathrm{S} / \mathrm{cm}$

\begin{tabular}{|c|c|c|c|c|c|c|c|c|c|}
\hline Depth & {$\left[\mathrm{Ca}^{2 \pm}\right]$} & {$\left[\mathrm{Mg}^{2+}\right]$} & {$\left[\mathrm{Na}^{ \pm}\right]$} & {$\left[K^{ \pm}\right]$} & $\begin{array}{l}\text { June } \\
{[\mathrm{Cl}=]}\end{array}$ & $\begin{array}{l}1993 \\
{\left[\mathrm{SO}_{2}{ }^{2-}\right]}\end{array}$ & {$\left[\mathrm{HCO}_{3}=\right]^{1}$} & Alka & Cond \\
\hline \multicolumn{10}{|c|}{ station 1} \\
\hline $1 \mathrm{~m}$ & 7.28 & 1.19 & 2.03 & 0.28 & 0.91 & 6.02 & 24.74 & 404.27 & 55 \\
\hline 8 & 7.60 & 1.22 & 2.07 & 0.28 & 0.96 & 6.25 & ---- & $\ldots-\infty$ & \\
\hline 29 & 7.72 & 1.32 & 2.25 & 0.35 & 1.15 & 6.31 & 26.09 & 426.29 & - \\
\hline \multicolumn{10}{|c|}{ Station 2} \\
\hline 1 & 7.43 & 1.21 & 2.04 & 0.29 & 0.91 & 6.06 & 31.26 & 510.72 & 5 \\
\hline 8 & 7.39 & 1.24 & 2.14 & 0.29 & 0.96 & 5.96 & 24.70 & 403.61 & \\
\hline 25 & 7.58 & 1.33 & 2.17 & 0.33 & 1.14 & 6.59 & 26.81 & 438.02 & $5 \% .7$ \\
\hline
\end{tabular}

\begin{tabular}{|c|c|c|c|c|c|c|c|c|c|}
\hline Depth & {$\left[\mathrm{Ca}^{2+}\right]$} & {$\left[\mathrm{Mg}^{2+}\right]$} & {$\left[\mathrm{Na}^{ \pm}\right]$} & $\begin{array}{r}17 \\
{\left[\mathrm{~K}^{ \pm}\right]}\end{array}$ & $\begin{array}{c}\text { September } \\
{[\mathrm{Cl}=]}\end{array}$ & $\begin{array}{l}1993 \\
{[50,2]}\end{array}$ & {$\left[\mathrm{HCO}_{3}=\right] \underline{1}$} & Alka & Cond \\
\hline \multicolumn{10}{|c|}{ station 1} \\
\hline $1 \mathrm{~m}$ & 7.66 & 1.27 & 2.18 & 0.29 & 0.94 & 5.97 & --- & $-\cdots-\cdots$ & -- \\
\hline 10 & 7.61 & 1.27 & 2.13 & 0.30 & 1.01 & 5.97 & 27.60 & 451.01 & 60.7 \\
\hline 29 & 8.16 & 1.38 & 2.41 & 0.38 & 1.32 & 6.25 & 31.85 & 520.36 & 55.9 \\
\hline \multicolumn{10}{|c|}{ Station 2} \\
\hline 1 & 7.58 & 1.27 & 2.13 & 0.30 & 0.94 & 6.09 & 28.13 & 459.57 & 5 \\
\hline 10 & 7.66 & 1.28 & 2.13 & 0.32 & 1.03 & 6.18 & 25.93 & 423.72 & \\
\hline 25 & 8.01 & 1.32 & 2.26 & 0.34 & 1.21 & 6.47 & 27.27 & 445.63 & \\
\hline
\end{tabular}

${ }^{1}$ Calculated from alkalinity data; $\left[\mathrm{HCO}_{3}{ }^{-}\right]=$Alka $* 0.0612$

- indicates missing or unreliable data 


\section{CHEMICAL DATA FOR COLDWATER LAKE \\ SAMPLE SEASON 1993 \\ Ion concentrations as $\mathrm{mg} / \mathrm{L}$ Alkalinity as $\mu \mathrm{eq} / L$ Conductivity as $\mu \mathrm{S} / \mathrm{cm}$}

\begin{tabular}{|c|c|c|c|c|c|c|c|c|c|}
\hline Depth & {$\left[\mathrm{Ca}^{2+}\right]$} & {$\left[\mathrm{Mg}^{2+}\right]$} & {$\left[\mathrm{Na}^{ \pm}\right]$} & {$\left[\mathrm{K}^{ \pm}\right]$} & $\begin{array}{l}\text { March } \\
{[C l=]}\end{array}$ & $\begin{array}{l}1993 \\
{\left[\mathrm{SO}^{2-}\right]}\end{array}$ & {$\left[\mathrm{HCO}_{3}=\right]^{1}$} & Alka & Cond \\
\hline station & 1 & & & & & & & & \\
\hline $\begin{array}{l}\text { 1m } \\
56 \\
\text { station }\end{array}$ & $\begin{array}{l}10.39 \\
10.83 \\
2\end{array}$ & $\begin{array}{l}2.38 \\
2.35\end{array}$ & $\begin{array}{l}7.30 \\
7.21\end{array}$ & $\begin{array}{l}0.98 \\
0.96\end{array}$ & $\begin{array}{l}4.51 \\
4.52\end{array}$ & $\begin{array}{l}28.49 \\
28.38\end{array}$ & $\begin{array}{l}23.82 \\
24.12\end{array}$ & $\begin{array}{l}389.17 \\
394.16\end{array}$ & $\begin{array}{l}111.1 \\
112.1\end{array}$ \\
\hline $\begin{array}{l}1 \\
40\end{array}$ & $\begin{array}{l}10.67 \\
10.68\end{array}$ & $\begin{array}{l}2.35 \\
2.36\end{array}$ & $\begin{array}{l}7.25 \\
7.15\end{array}$ & $\begin{array}{l}0.97 \\
0.99\end{array}$ & $\begin{array}{l}4.50 \\
4.51\end{array}$ & $\begin{array}{l}28.61 \\
28.26\end{array}$ & $\begin{array}{l}23.75 \\
23.97\end{array}$ & $\begin{array}{l}388.06 \\
391.59\end{array}$ & $\begin{array}{l}112.5 \\
113.2\end{array}$ \\
\hline
\end{tabular}

\begin{tabular}{|c|c|c|c|c|c|c|c|c|c|}
\hline Depth & {$\left[\mathrm{Ca}^{2 \pm}\right]$} & {$\left[\mathrm{Mg}^{2 \pm}\right]$} & {$\left[\mathrm{Na}^{ \pm}\right]$} & {$\left[\mathrm{K}^{ \pm}\right]$} & $\begin{array}{l}\text { August } \\
{[\mathrm{Cl}=]}\end{array}$ & $\begin{array}{l}1993 \\
{\left[5 O_{0}=\right]}\end{array}$ & {$\left[\mathrm{HCO}_{3}=\right]^{1}$} & Alka & Cond \\
\hline \multicolumn{10}{|c|}{ station 1} \\
\hline $1 \mathrm{~m}$ & 8.79 & 1.92 & 5.06 & 0.75 & 2.62 & 21.89 & 19.18 & 313.38 & 9 \\
\hline 7 & 8.67 & 1.96 & 5.18 & 0.75 & 2.68 & 21.94 & 20.15 & 329.26 & \\
\hline $\begin{array}{l}35 \\
\text { station }\end{array}$ & $\begin{array}{l}10.68 \\
2\end{array}$ & 2.31 & 7.07 & 0.94 & 4.36 & 27.24 & 25.23 & 412.28 & 106. \\
\hline 1 & 8.76 & 1.96 & 4.97 & 0.73 & 2.63 & 22.02 & 19.48 & 318.33 & 90.0 \\
\hline 7 & 8.67 & 1.93 & 5.20 & 0.73 & 2.64 & 20.90 & 19.69 & 321.73 & 88 \\
\hline 45 & 10.58 & 2.31 & 6.91 & 0.93 & 4.29 & 27.13 & 25.67 & 419.44 & \\
\hline
\end{tabular}




\section{CHEMICAL DATA FOR COLDWATER LAKE \\ SAMPLE SEASON 1993 \\ (CONTINUED)}

Ion Concentrations as $\mathrm{mg} / \mathrm{L}$

Alkalinity as $\mu \mathrm{eq} / \mathrm{L}$

Conductivity as $\mu \mathrm{S} / \mathrm{cm}$

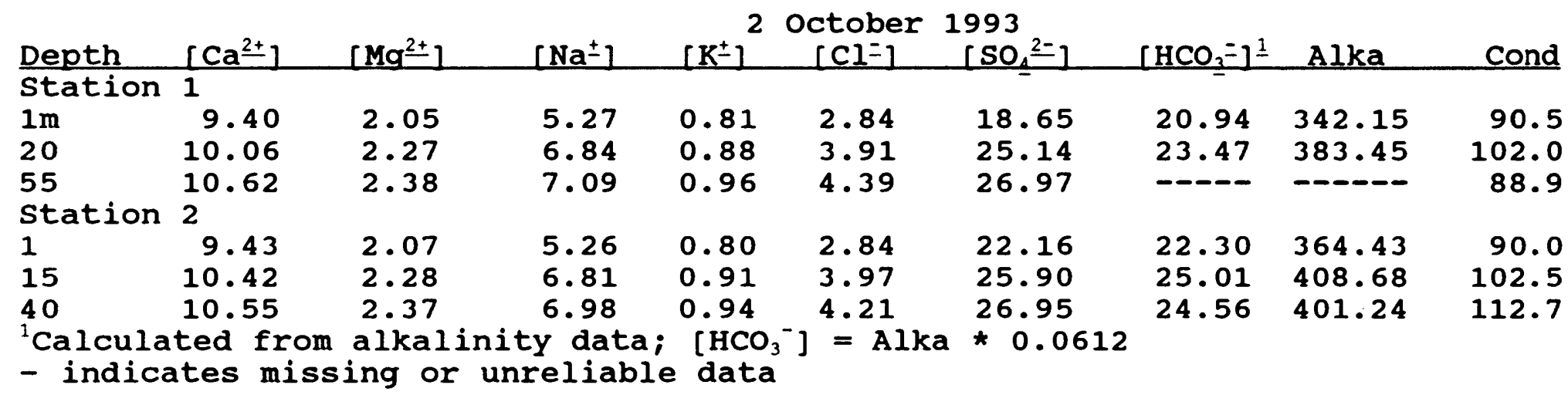


CHEMICAL DATA FOR JUNE LAKE

SAMPLE SEASON 1993

Ion Concentrations as $\mathrm{mg} / \mathrm{L}$

Alkalinity as $\mu \mathrm{eq} / \mathrm{L}$

Conductivity as $\mu \mathrm{s} / \mathrm{cm}$

\begin{tabular}{|c|c|c|c|c|c|c|c|c|c|}
\hline Depth & {$\left[\mathrm{Ca}^{2 \pm}\right]$} & {$\left[\mathrm{Mq}^{2+}\right]$} & {$\left[\mathrm{Na}^{ \pm}\right]$} & {$\left[\mathrm{K}^{ \pm}\right]$} & $\begin{array}{l}9 \text { May } \\
{\left[\mathrm{Cl}^{\prime}=1\right.}\end{array}$ & 1993 & {$\left[\mathrm{HCO}_{3}=1\right]$} & Alka & Cond \\
\hline $\begin{array}{l}1 \mathrm{~m} \\
1.5\end{array}$ & $\begin{array}{l}2.88 \\
2.79\end{array}$ & $\begin{array}{l}1.09 \\
0.84\end{array}$ & $\begin{array}{l}5.84 \\
3.78\end{array}$ & $\begin{array}{l}0.85 \\
0.76\end{array}$ & $\begin{array}{l}1.89 \\
2.19\end{array}$ & $\begin{array}{l}5.13 \\
5.34\end{array}$ & $\begin{array}{l}12.67 \\
15.06\end{array}$ & $\begin{array}{l}207.01 \\
246.04\end{array}$ & $\begin{array}{l}36.3 \\
46.7\end{array}$ \\
\hline
\end{tabular}

9 September 1993



17 October 1993

\begin{tabular}{lccccccccc} 
Depth & {$\left[\mathrm{Ca}^{2+}\right]$} & {$\left[\mathrm{Mg}^{2+}\right]$} & {$\left[\mathrm{Na}^{ \pm}\right]$} & {$\left[\mathrm{K}^{ \pm}\right]$} & {$\left[\mathrm{Cl}^{2}\right]$} & {$\left[\mathrm{SO}_{4}^{2-}\right]$} & {$\left[\mathrm{HCO}_{3}=\underline{1}\right.$} & $\mathrm{A}] \mathrm{ka}$ & $\mathrm{Cond}$ \\
\hline $\mathrm{m}$ & 4.75 & 1.92 & 10.31 & 1.31 & 4.43 & 9.01 & 34.76 & 567.90 & 87.2
\end{tabular}

${ }^{1}$ Calculated from alkalinity data; $\left[\mathrm{HCO}_{3}{ }^{-}\right]=\mathrm{Alka} * 0.0612$ 


\section{CHEMICAL DATA FOR MCBRIDE LAKE \\ SAMPLE SEASON 1993 \\ Ion Concentrations as $\mathrm{mg} / \mathrm{L}$ \\ Alkalinity as $\mu \mathrm{eq} / \mathrm{L}$ \\ Conductivity as $\mu \mathrm{S} / \mathrm{cm}$}

\begin{tabular}{|c|c|c|c|c|c|c|c|c|c|}
\hline Depth & {$\left[\mathrm{Ca}^{2+}\right]$} & {$\left[\mathrm{Mq}^{2+}\right]$} & {$\left[\mathrm{Na}^{ \pm}\right]$} & {$\left[\mathrm{K}^{ \pm}\right]$} & $\begin{array}{l}9 \text { May } \\
{\left[\mathrm{Cl}^{\prime}=\right]}\end{array}$ & 1993 & {$\left[\mathrm{HCO}_{2}=\right]^{1}$} & Alka & Cond \\
\hline \multicolumn{10}{|c|}{ Replicate A } \\
\hline $1 \mathrm{~m}$ & 2.48 & 0.62 & 1.66 & 0.12 & 0.87 & 0.61 & 12.81 & 209.27 & 24.0 \\
\hline $\begin{array}{l}1.75 \\
\text { Replic }\end{array}$ & $e^{2.58}$ & 0.66 & 1.73 & 0.14 & 0.92 & 0.61 & & & \\
\hline 12 & 2.57 & 0.65 & 1.69 & 0.14 & 0.89 & 0.63 & 13.56 & 221.57 & 24.1 \\
\hline 1.75 & 2.53 & 0.64 & 1.67 & 0.14 & 0.87 & 0.68 & 13.03 & 212.98 & 21.2 \\
\hline
\end{tabular}

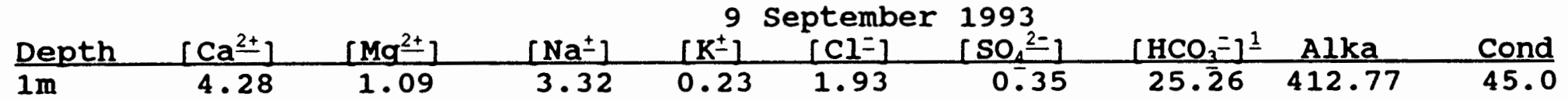

\begin{tabular}{lccccccccc} 
Depth & {$\left[\mathrm{Ca}^{2+}\right]$} & {$\left[\mathrm{Mg}^{2+}\right]$} & {$\left[\mathrm{Na}^{ \pm}\right]$} & {$\left[\mathrm{K}^{ \pm}\right]$} & {$[\mathrm{Cl}=]$} & {$\left[\mathrm{SO}_{1}^{2-}\right]$} & {$\left[\mathrm{HCO}_{3}\right] 1$} & Alka & Cond \\
\hline $1 \mathrm{~m}$ & 4.87 & 1.18 & 3.71 & 0.41 & 2.39 & 0.53 & 27.18 & 444.10 & 49.8
\end{tabular}

${ }^{1}$ Calculated from alkalinity data; $\left[\mathrm{HCO}_{3}{ }^{-}\right]=\mathrm{Alka} * 0.0612$

- indicates missing or unreliable data 


\section{CHEMICAL DATA FOR MERRILL LAKE \\ SAMPLE SEASON 1993
Ion Concentrations as $\mathrm{mg} / \mathrm{L}$
Alkalinity as $\mu \mathrm{eq} / \mathrm{L}$
Conductivity as $\mu \mathrm{S} / \mathrm{cm}$

\begin{tabular}{|c|c|c|c|c|c|c|c|c|c|}
\hline Depth & {$\left[\mathrm{Ca}^{2+}\right]$} & {$\left[\mathrm{Mg}^{2+}\right]$} & {$\left[\mathrm{Na}^{ \pm}\right]$} & {$\left[\mathrm{K}^{ \pm}\right]^{17}$} & $\begin{array}{l}\text { April } \\
{[\mathrm{C} I=]}\end{array}$ & $\begin{array}{l}1993 \\
{\left[\mathrm{SO}_{2}=\right]}\end{array}$ & {$\left[\mathrm{HCO}_{3}=\right]^{1}$} & Alka & Cond \\
\hline \multicolumn{10}{|c|}{$\begin{array}{l}\text { Station } 1 \\
\text { Replicate A }\end{array}$} \\
\hline $1 \mathrm{~m}$ & 2.30 & 0.45 & 1.51 & 0.05 & 0.83 & 0.74 & $-\cdots--$ & $---\infty$ & --- \\
\hline 10 & 2.34 & 0.44 & 1.50 & 0.07 & 0.82 & 0.55 & 13.17 & 215.19 & 21.5 \\
\hline 15 & 2.32 & 0.45 & 1.49 & 0.06 & 0.80 & 0.57 & 13.50 & 220.63 & \\
\hline \multicolumn{10}{|c|}{ Replicate B } \\
\hline 1 & 2.29 & 0.45 & 1.48 & 0.06 & 0.80 & 0.78 & 14.22 & 232.29 & 21.0 \\
\hline $\begin{array}{l}10 \\
15\end{array}$ & $\begin{array}{l}2.29 \\
2.26\end{array}$ & $\begin{array}{l}0.45 \\
0.46\end{array}$ & 1.53 & $\begin{array}{l}0.06 \\
0.08\end{array}$ & $\begin{array}{l}0.80 \\
0.83\end{array}$ & $\begin{array}{l}0.59 \\
0.61\end{array}$ & $\begin{array}{l}13.01 \\
12.97\end{array}$ & $\begin{array}{l}212.51 \\
211.92\end{array}$ & 21.8 \\
\hline \multicolumn{10}{|c|}{$\begin{array}{l}\text { Station } 2 \\
\text { Replicate } \mathrm{A}\end{array}$} \\
\hline 1 & 2.32 & 0.45 & 1.43 & 0.09 & 0.78 & 0.51 & 11.61 & 189.72 & 20.9 \\
\hline 10 & 2.15 & 0.46 & 1.49 & 0.04 & 0.82 & 0.74 & 12.18 & 198.94 & 21.8 \\
\hline & 2.23 & 0.44 & 1.45 & 0.09 & 0.83 & 0.66 & 12.12 & 198.06 & 21.0 \\
\hline \multicolumn{10}{|c|}{ Replicate B } \\
\hline 1 & 2.23 & 0.45 & 1.49 & 0.09 & 0.81 & 1.89 & 12.91 & 210.97 & 21.0 \\
\hline 10 & 2.29 & 0.45 & 1.50 & 0.07 & 0.83 & 1.23 & $-\cdots$ & $\ldots$ & 21.2 \\
\hline 18 & 2.30 & 0.47 & 1.48 & 0.08 & 0.83 & 0.74 & ---- & $-\infty-\infty$ & 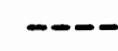 \\
\hline 1 & & alka. & da & {$\left[\mathrm{HCO}_{3}\right.$} & $=\mathrm{Alk}$ & $a * 0.0612$ & & & \\
\hline
\end{tabular}




\section{CHEMICAL DATA FOR MERRILL LAKE \\ SAMPLE SEASON 1993 \\ (CONTINUED)}

\section{Ion Concentrations as $\mathrm{mg} / \mathrm{L}$ \\ Alkalinity as $\mu \mathrm{eq} / \mathrm{L}$ \\ Conductivity as $\mu \mathrm{S} / \mathrm{cm}$}

\begin{tabular}{|c|c|c|c|c|c|c|c|c|c|}
\hline Depth & {$\left[\mathrm{Ca}^{2+}\right]$} & {$\left[\mathrm{Mg}^{2+}\right]$} & {$\left[\mathrm{Na}^{ \pm}\right]$} & $\begin{array}{r}8 \\
{\left[K^{ \pm}\right]} \\
\end{array}$ & $\begin{array}{c}\text { September } \\
{\left[\mathrm{Cl}^{-}=\right]}\end{array}$ & $\begin{array}{l}1993 \\
{\left[\mathrm{SO}_{4}=1\right.}\end{array}$ & {$\left[\mathrm{HCO}_{3}=\right]^{1}$} & Alka & Cond \\
\hline \multicolumn{10}{|c|}{ station 1} \\
\hline $1 \mathrm{~m}$ & 2.54 & 0.50 & 1.64 & 0.09 & 0.77 & 0.58 & 13.21 & 215.78 & 26.0 \\
\hline 4 & 2.56 & 0.48 & 1.64 & 0.08 & 0.77 & --- & 13.21 & 215.78 & 26.0 \\
\hline 10 & 2.57 & 0.49 & 1.52 & 0.10 & 0.73 & 0.58 & 12.33 & 201.47 & 26.0 \\
\hline \multicolumn{10}{|c|}{ Station 2} \\
\hline 1 & 2.43 & 0.49 & 1.55 & 0.11 & 0.77 & 0.57 & 12.89 & 210.63 & 27.0 \\
\hline 4 & 2.47 & 0.51 & 1.64 & 0.08 & 0.77 & 0.44 & 13.01 & 212.56 & 26.0 \\
\hline 12 & 2.50 & 0.45 & 1.44 & 0.11 & 0.77 & 0.16 & 12.59 & 205.75 & 26.0 \\
\hline
\end{tabular}




\section{CHEMICAL DATA FOR MERRILL LAKE \\ SAMPLE SEASON 1993 \\ (CONTINUED)}

\section{Ion Concentrations as $\mathrm{mg} / \mathrm{L}$ \\ Alkalinity as $\mu \mathrm{eq} / \mathrm{L}$ Conductivity as $\mu \mathrm{S} / \mathrm{cm}$}

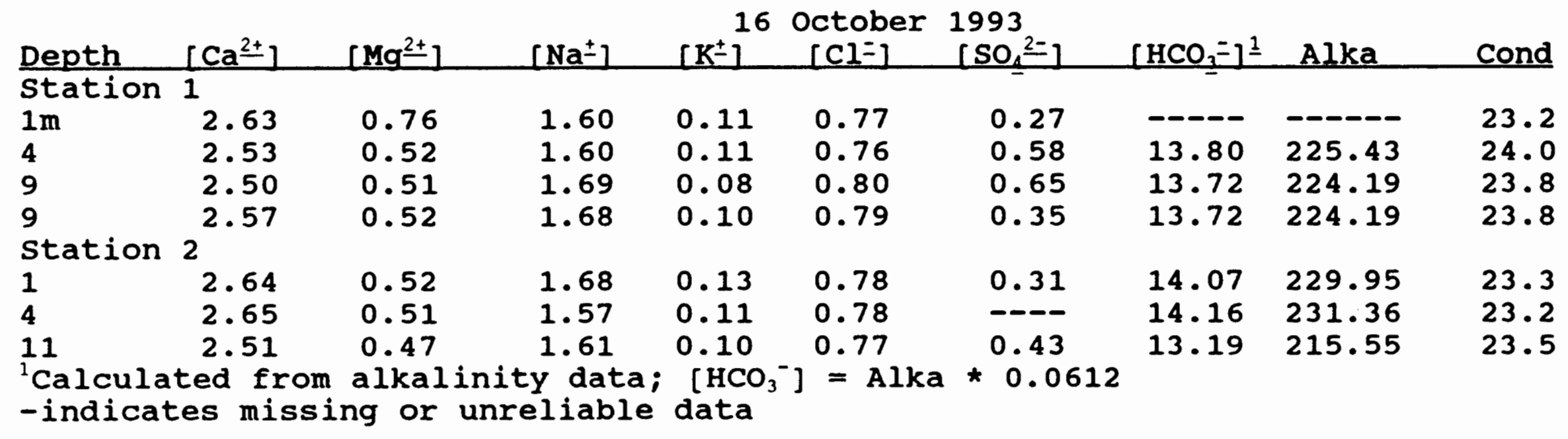


CHEMICAL DATA FOR PANHANDLE LAKE

SAMPLE SEASON 1994

Ion Concentrations as $\mathrm{mg} / \mathrm{L}$

Alkalinity as $\mu \mathrm{eq} / \mathrm{L}$

Conductivity as $\mu \mathrm{S} / \mathrm{cm}$

\begin{tabular}{|c|c|c|c|c|c|c|c|c|c|}
\hline Depth & {$\left[\mathrm{Ca}^{2+}\right]$} & {$\left[\mathrm{Mg}^{2+}\right]$} & {$\left[\mathrm{Na}^{ \pm}\right]$} & {$\left[\mathrm{K}^{ \pm}\right]$} & $\begin{array}{l}\text { July } \\
{[C 1=]}\end{array}$ & $\begin{array}{c}1994 \\
{\left[\mathrm{SO}_{2} 2=\right]}\end{array}$ & {$\left[\mathrm{HCO}_{3}=\right]^{1}$} & Alka & Cond \\
\hline \multicolumn{10}{|c|}{ Replicate A } \\
\hline $\begin{array}{l}1 \mathrm{~m} \\
4\end{array}$ & $\begin{array}{l}2.40 \\
2.51\end{array}$ & $\begin{array}{l}0.54 \\
0.53\end{array}$ & $\begin{array}{l}1.07 \\
1.05\end{array}$ & $\begin{array}{l}0.34 \\
0.33\end{array}$ & $\begin{array}{l}0.48 \\
0.48\end{array}$ & $\begin{array}{l}6.98 \\
7.12\end{array}$ & $\begin{array}{l}3.37 \\
2.45\end{array}$ & $\begin{array}{l}55.01 \\
39.95\end{array}$ & $\begin{array}{l}22.0 \\
23.4\end{array}$ \\
\hline & 3.40 & 0.77 & 1.45 & 0.58 & 0.61 & 8.89 & 5.85 & 95.66 & 31.1 \\
\hline \multicolumn{10}{|c|}{ Replicate B } \\
\hline 1 & 2.50 & 0.53 & 1.04 & 0.35 & 0.47 & 7.02 & 3.00 & 48.97 & 21.7 \\
\hline 4 & 2.57 & 0.54 & 1.06 & 0.34 & 0.47 & 7.02 & 2.33 & 38.09 & 23.1 \\
\hline 18 & 3.36 & 0.78 & 1.42 & 0.57 & 0.61 & 8.87 & 5.50 & 89.92 & 31.8 \\
\hline
\end{tabular}

${ }^{3}$ Calculated from alkalinity data; $\left[\mathrm{HCO}_{3}{ }^{-}\right]=\mathrm{Alka} * 0.0612$ 


\section{CHEMICAL DATA FOR BOOT LAKE \\ SAMPLE SEASON 1994}

\section{Ion Concentrations as $\mathrm{mg} / \mathrm{L}$ Alkalinity as $\mu \mathrm{eq} / \mathrm{L}$ Conductivity as $\mu \mathrm{s} / \mathrm{cm}$}

\begin{tabular}{|c|c|c|c|c|c|c|c|c|c|}
\hline Depth & {$\left[\mathrm{Ca}^{2 \pm}\right]$} & {$\left[\mathrm{Mg}^{2+}\right]$} & {$\left[\mathrm{Na}^{ \pm}\right]$} & {$\left[\mathrm{K}^{ \pm}\right]$} & $\begin{array}{l}\text { July } \\
[C]=]\end{array}$ & $\begin{array}{r}1994 \\
{\left[\mathrm{SO}_{1} \leq-\right]}\end{array}$ & {$\left[\mathrm{HCO}_{3}=\right]^{1}$} & Alka & Cond \\
\hline \multicolumn{10}{|c|}{ Replicate A } \\
\hline $1 \mathrm{~m}$ & $\begin{array}{l}3.05 \\
3.10\end{array}$ & $\begin{array}{l}0.63 \\
0.62\end{array}$ & $\begin{array}{l}1.16 \\
1.14\end{array}$ & $\begin{array}{l}0.25 \\
0.23\end{array}$ & $\begin{array}{l}0.42 \\
0.45\end{array}$ & $\begin{array}{r}8.73 \\
8.49\end{array}$ & $\begin{array}{r}2.65 \\
2.74\end{array}$ & $\begin{array}{r}43.32 \\
44.80\end{array}$ & $\begin{array}{l}28.2 \\
27.1\end{array}$ \\
\hline \multicolumn{10}{|c|}{ Replicate B } \\
\hline 1 & $\begin{array}{l}3.09 \\
3.07\end{array}$ & $\begin{array}{l}0.62 \\
0.63\end{array}$ & $\begin{array}{l}1.13 \\
1.16\end{array}$ & $\begin{array}{l}0.26 \\
0.24\end{array}$ & $\begin{array}{l}0.45 \\
0.43 \\
0.72\end{array}$ & $\begin{array}{r}8.39 \\
8.59\end{array}$ & $\begin{array}{l}2.60 \\
2.64\end{array}$ & $\begin{array}{r}42.46 \\
43.16 \\
153.59\end{array}$ & $\begin{array}{l}29.0 \\
26.5\end{array}$ \\
\hline $\begin{array}{l}13 \\
{ }^{1} \mathrm{Cal}\end{array}$ & 4.87 & 1.03 & 1.76 & 0.38 & 0.72 & 10.98 & 9.40 & 153.59 & 41.1 \\
\hline
\end{tabular}


CHEMICAL DATA FOR ST. HELENS LAKE

SAMPLE SEASON 1994

Ion Concentrations as $\mathrm{mg} / \mathrm{L}$

Alkalinity as $\mu \mathrm{eq} / \mathrm{L}$

Conductivity as $\mu \mathrm{S} / \mathrm{cm}$

\begin{tabular}{|c|c|c|c|c|c|c|c|c|c|}
\hline Depth & {$\left[\mathrm{Ca}^{2+}\right]$} & {$\left[\mathrm{Mq}^{2+}\right]$} & {$\left[\mathrm{Na}^{ \pm}\right]$} & {$\left[\mathrm{K}^{ \pm}\right]$} & $\begin{array}{l}\text { July } \\
{\left[\mathrm{Cl}^{\prime}\right]}\end{array}$ & $\begin{array}{r}1994 \\
{[50,2-]}\end{array}$ & {$\left[\mathrm{HCO}_{3}=\right]^{1}$} & Alka & Cond \\
\hline \multicolumn{10}{|c|}{ Replicate $\mathrm{A}$} \\
\hline $1 \mathrm{~m}$ & 8.36 & 1.43 & 3.03 & 0.82 & 3.11 & 21.08 & 9.64 & 157.53 & 72.0 \\
\hline 7 & 8.30 & 1.45 & 3.02 & 0.84 & 3.12 & 20.98 & 8.45 & 138.15 & 78.5 \\
\hline & 9.29 & 1.57 & 3.51 & 1.01 & 3.91 & 23.30 & 11.26 & 183.96 & 79.5 \\
\hline \multicolumn{10}{|c|}{ Replicate B } \\
\hline 1 & 8.38 & 1.44 & 3.04 & 0.82 & 3.12 & 20.92 & 9.74 & 159.17 & 74.5 \\
\hline 7 & 8.39 & 1.46 & 3.03 & 0.84 & 3.12 & 20.96 & 8.45 & 138.09 & 77.5 \\
\hline 75 & 9.37 & 1.55 & 3.53 & 1.01 & 3.92 & 23.32 & 11.15 & 182.18 & 80.5 \\
\hline
\end{tabular}




\section{APPENDIX F}

TEMPERATURE PROFILES OF STUDY LAKES 
TEMPERATURE PROFILE FOR PANHANDLE LAKE (Temperatures in ${ }^{\circ} \mathrm{C}$ )

\begin{tabular}{lc} 
Depth & $8 / 14 / 93$ \\
\hline $0 \mathrm{~m}$ & 13.5 \\
1 & 13.5 \\
2 & 13.5 \\
3 & 13.0 \\
4 & 12.5 \\
5 & 11.0 \\
6 & 10.5 \\
7 & 9.5 \\
8 & 9.0 \\
9 & 8.2 \\
10 & 7.0 \\
11 & 6.5 \\
12 & 6.0 \\
13 & 5.5 \\
14 & 5.0 \\
15 & 5.0 \\
16 & 4.9 \\
17 & 4.5 \\
18 & 4.3 \\
18.5 & 4.3
\end{tabular}


TEMPERATURE PROFILE FOR BOOT LAKE

(Temperatures in ${ }^{\circ} \mathrm{C}$ )

\begin{tabular}{lc} 
Depth & $8 / 15 / 93$ \\
\hline m & 12.0 \\
1 & 12.0 \\
2 & 12.0 \\
3 & 12.0 \\
4 & 11.5 \\
5 & 9.5 \\
6 & 8.5 \\
7 & 7.3 \\
8 & 7.0 \\
9 & 6.2 \\
10 & 6.0 \\
11 & 5.4 \\
12 & 5.1 \\
13 & 5.0 \\
14 & 5.0 \\
15 & 5.0
\end{tabular}


TEMPERATURE PROFILE FOR FAWN LAKE

(Temperatures in ${ }^{\circ} \mathrm{C}$ )

$\begin{array}{lccc}\text { Depth } & \frac{5 / 22 / 93}{0 \mathrm{~m}} & \frac{8 / 05 / 93}{20.0} & \frac{10 / 02 / 93}{11.0} \\ 1 & 11.0 & 19.2 & 14.0 \\ 2 & 11.0 & 16.4 & 13.8 \\ 3 & 11.0 & 14.9 & 13.8 \\ 4 & 10.5 & 13.8 & 13.8 \\ 5 & 8.0 & 13.1 & 13.5 \\ 6 & 7.4 & 12.6 & 13.5 \\ 7 & 7.0 & 12.0 & 13.1 \\ 8 & 6.4 & 10.2 & 13.0 \\ 9 & 6.0 & 8.5 & 12.2 \\ 10 & 5.9 & 7.2 & 10.5 \\ 11 & 5.5 & 6.2 & 8.6 \\ 12 & 5.5 & 6.0 & 7.4 \\ 13 & 5.3 & 5.9 & 6.5 \\ 14 & 5.2 & 5.5 & 6.0 \\ 15 & 5.1 & 5.4 & 5.9 \\ 16 & 5.0 & & 5.6 \\ 17 & 5.0 & & 5.5 \\ 18 & 5.0 & & 5.3 \\ 19 & 5.0 & & \\ 20 & 5.0 & & \end{array}$


TEMPERATURE PROFILE FOR HANAFORD IAAKE

(Temperatures in ${ }^{\circ} \mathrm{C}$ )

$\begin{array}{lrrr}\text { Depth } & \frac{5 / 22 / 93}{10.9} & \frac{8 / 05 / 93}{18.8} & \frac{10 / 02 / 93}{14.0} \\ 1 & 11.0 & 18.8 & 14.0 \\ 2 & 11.0 & 17.5 & 13.9 \\ 3 & 11.0 & 15.7 & 13.7 \\ 4 & 9.0 & 14.3 & 13.5 \\ 5 & 8.2 & 13.8 & 13.4 \\ 6 & 7.5 & 13.3 & 13.2 \\ 7 & 6.9 & 13.0 & 13.1 \\ 8 & 6.3 & 12.8 & 13.1 \\ 9 & 6.0 & 12.1 & 13.0 \\ 10 & 6.0 & 11.2 & 13.0 \\ 11 & 6.0 & 10.0 & 12.9 \\ 12 & 5.8 & 9.4 & 12.8 \\ 13 & 5.5 & 9.2 & 11.9 \\ 14 & 5.5 & 9.0 & 11.5 \\ 15 & 5.4 & 9.0 & \\ 16 & 5.4 & & \end{array}$


TEMPERATURE PROFILE FOR RYAN LAKE

(Temperatures in ${ }^{\circ} \mathrm{C}$ )

$\begin{array}{lcrc}\text { Depth } & \frac{6 / 17 / 93}{14.5} & \frac{8 / 24 / 93}{16.2} & \frac{10 / 09 / 93}{13.0} \\ \text { Om } & 14.2 & 16.2 & 13.0 \\ 1 & & 16.2 & 12.7 \\ 2 & 12.9 & 16.2 & 12.7 \\ 3 & 12.1 & 16.1 & 12.6 \\ 4 & 11.5 & 14.9 & 12.6 \\ 5 & 11.2 & 13.6 & 12.5 \\ 6 & 10.6 & & 12.2\end{array}$


135

TEMPERATURE PROFILE FOR ST. HELEN LAKE

(Temperatures in ${ }^{\circ} \mathrm{C}$ )

Depth

om

5

10

15

20

25

30

35

40

45

50

55

60 $\frac{8 / 10 / 93}{14.0}$

11.0

8.0

5.0

4.0

4.0

3.5

3.5

3.0

3.0

3.0

3.0

3.0

. 
TEMPERATURE PROFILE FOR VENUS LAKE (Temperatures in ${ }^{\circ} \mathrm{C}$ )

\begin{tabular}{lc} 
Depth & $8 / 09 / 93$ \\
\hline Om & 14.0 \\
1 & 13.0 \\
2 & 13.0 \\
3 & 13.0 \\
4 & 12.5 \\
5 & 12.0 \\
6 & 10.5 \\
7 & 10.0 \\
8 & 8.5 \\
9 & 7.0 \\
10 & 6.5 \\
12 & 6.0 \\
14 & 5.5 \\
16 & 5.0 \\
18 & 4.5 \\
20 & 4.0 \\
22 & 3.5 \\
24 & 3.5 \\
26 & 3.5 \\
28 & 3.0 \\
30 & 3.0 \\
32 & 3.0 \\
34 & 3.0 \\
36 & 3.0 \\
38 & 3.0 \\
39 & 3.0
\end{tabular}


TEMPERATURE PROFILE FOR CASTI.E LAKE

(Temperatures in ${ }^{\circ} \mathrm{C}$ )

\begin{tabular}{|c|c|c|c|}
\hline Depth & $\begin{array}{l}\text { Station } 1 \\
6 / 26 / 93\end{array}$ & $\begin{array}{l}\text { Station } 1 \\
9 / 17 / 93\end{array}$ & $\begin{array}{l}\text { station } \\
9 / 17 / 93\end{array}$ \\
\hline Om & 16.5 & & \\
\hline 1 & 16.5 & 16.1 & 17.0 \\
\hline 2 & 16.5 & 16.2 & 17.0 \\
\hline 3 & 15.6 & 16.2 & 17.0 \\
\hline 4 & 14.2 & 16.3 & 16.7 \\
\hline 5 & 13.5 & 16.3 & 16.7 \\
\hline 6 & 13.0 & 16.2 & 16.6 \\
\hline 7 & 12.2 & 16.2 & 16.2 \\
\hline 8 & 11.0 & 16.1 & 16.0 \\
\hline 9 & 9.9 & 12.2 & 15.0 \\
\hline 10 & 9.0 & 10.7 & 11.0 \\
\hline 12 & 7.2 & 8.0 & 8.5 \\
\hline 14 & 6.4 & 7.1 & 8.0 \\
\hline 16 & 6.0 & 6.2 & 7.0 \\
\hline 18 & 5.7 & 6.0 & 6.9 \\
\hline 20 & 5.4 & 5.5 & 5.9 \\
\hline 22 & & 5.4 & 6.0 \\
\hline 24 & & 5.2 & 5.9 \\
\hline 25 & 5.1 & & \\
\hline 26 & & 5.2 & 5.4 \\
\hline 28 & & 5.2 & 5.2 \\
\hline 30 & 5.0 & 5.2 & 5.1 \\
\hline 32 & & 5.2 & 5.0 \\
\hline 34 & & 5.3 & \\
\hline 36 & & 5.5 & \\
\hline
\end{tabular}


TEMPERATURE PROFILE FOR COLDWATER IAAKE

(Temperatures in ${ }^{\circ} \mathrm{C}$ )

\begin{tabular}{|c|c|c|c|}
\hline Depth & $3 / 24 / 93$ & $8 / 04 / 93$ & $10 / 02 / 93$ \\
\hline $\mathrm{Om}$ & 3.5 & 21.0 & 16.1 \\
\hline 1 & 3.3 & 21.0 & \\
\hline 2 & 3.3 & 20.0 & \\
\hline 3 & 3.2 & 17.0 & \\
\hline 4 & 3.2 & 15.5 & \\
\hline 5 & 3.2 & 15.1 & 15.2 \\
\hline 6 & 3.2 & 14.9 & \\
\hline 7 & 3.2 & 14.0 & \\
\hline 8 & & 13.0 & \\
\hline 9 & & 12.0 & \\
\hline 10 & & 10.5 & 13.0 \\
\hline 11 & & 9.5 & \\
\hline 12 & & 8.5 & \\
\hline 13 & & 7.7 & \\
\hline 14 & & 7.4 & \\
\hline 15 & & 7.0 & 7.8 \\
\hline 20 & & & 6.2 \\
\hline 22 & 3.2 & & \\
\hline 23 & 3.1 & & \\
\hline 24 & 3.1 & & \\
\hline 25 & 3.1 & & 5.2 \\
\hline 30 & 3.1 & & 5.0 \\
\hline 35 & & & 4.8 \\
\hline 40 & & & 4.7 \\
\hline 45 & & & 4.7 \\
\hline 50 & & & 4.5 \\
\hline 55 & & & 4.5 \\
\hline 60 & & & 4.5 \\
\hline
\end{tabular}


TEMPERATURE PROFILE FOR JUNE LAKE

(Temperatures in ${ }^{\circ} \mathrm{C}$ )

$\begin{array}{lccc}\text { Depth } & \frac{5 / 28 / 93}{0 m} & \frac{9 / 09 / 93}{8.0} & \frac{10 / 17 / 93}{4.2} \\ 0.5 & 5.0 & 8.0 & 4.2 \\ 1 & & 8.0 & 4.5 \\ 1.5 & 4.5 & 8.0 & 4.9\end{array}$


TEMPERATURE PROFILE FOR MCBRIDE LAKE (Temperatures in ${ }^{\circ} \mathrm{C}$ )

\section{Om \\ 0.5 \\ 1 \\ 1.5}

Depth

$5 / 28 / 93$

12.5

12.0

$9 / 09 / 93$

17.6

17.4

16.9

9.5

16.2

16.0

$\frac{10 / 17 / 93}{8.9}$

8.9

8.8

8.6

8.4 
TEMPERATURE PROFILE FOR MERRILL LAKE (Temperatures in ${ }^{\circ} \mathrm{C}$ )

\begin{tabular}{lcrr} 
Depth & $\frac{4 / 17 / 93}{7.5}$ & $\frac{9 / 08 / 93}{20.7}$ & $\frac{10 / 16 / 93}{14.7}$ \\
\hline m & & 20.4 & 14.7 \\
1 & & 20.2 & 14.7 \\
2 & & 20.0 & 14.7 \\
3 & & 19.8 & 14.7 \\
4 & & 19.0 & 14.7 \\
5 & 7.2 & 18.5 & 14.7 \\
6 & & 18.0 & 14.7 \\
7 & & 17.8 & 14.7 \\
8 & & 15.7 & 14.7 \\
9 & & 13.5 & \\
10 & & & \\
15 & 6.5 & & \\
17 & 6.0 & &
\end{tabular}

